University of Louisville

ThinkIR: The University of Louisville's Institutional Repository

$5-2011$

\title{
Species composition, demographics, and ecosystem services of residential trees in Louisville, Kentucky.
}

Shannon A. Scroggins

University of Louisville

Follow this and additional works at: https://ir.library.louisville.edu/etd

\section{Recommended Citation}

Scroggins, Shannon A., "Species composition, demographics, and ecosystem services of residential trees in Louisville, Kentucky." (2011). Electronic Theses and Dissertations. Paper 1293.

https://doi.org/10.18297/etd/1293

This Master's Thesis is brought to you for free and open access by ThinkIR: The University of Louisville's Institutional Repository. It has been accepted for inclusion in Electronic Theses and Dissertations by an authorized administrator of ThinkIR: The University of Louisville's Institutional Repository. This title appears here courtesy of the author, who has retained all other copyrights. For more information, please contact thinkir@louisville.edu. 


\title{
SPECIES COMPOSITION, DEMOGRAPHICS, AND ECOSYSTEM SERVICES OF
} RESIDENTIAL TREES IN LOUISVILLE, KENTUCKY

\section{By}

Shannon A. Scroggins

B.S.N., Jacksonville University, 2005

\author{
A Thesis \\ Submitted to the Faculty of the \\ College of Arts and Sciences of the University of Louisville \\ in Partial Fulfillment of the Requirements \\ for the Degree of
}

Master of Science

Department of Biology

University of Louisville

Louisville, Kentucky

May 2011 
SPECIES COMPOSITION, DEMOGRAPHICS, AND ECOSYSTEM SERVICES OF RESIDENTIAL TREES IN LOUISVILLE, KENTUCKY

\section{By}

Shannon A. Scroggins

B.S.N., Jacksonville University, 2005

A Thesis Approved on

March 28, 2011

By the following Thesis Committee:

Margaret M. Carreiro

Sarah Emery

Lauren Heberle 


\section{ACKNOWLEDGMENTS}

Thanks to the Kentucky Division of Forestry (grant GB071268) and the University of Louisville Research Foundation for funding my research. Dr. David Wicks (former director of the JCPS Center for Environmental Education) was responsible for organizing the matching assistance from Jefferson County Public Schools. Bryan Thompson (naturalist, JCPS Center for Environmental Education) led the second team of undergraduates who collected field data in 2008. Thanks also to Louisville Metro Parks for matching assistance from Adrian Camacho (Forestry Manager) and Rachel Habig. Adrian's dedication and extensive knowledge of trees were a huge help. He was always there to help me identify "mystery trees". Rachel Habig (forester, Louisville Metro Parks) was kind enough to take me out in the field with her throughout the winter of 2008 to teach me useful tree identification tips. Robert E. Hoehn III (Biological Sciences Technician, U.S. Forest Service, Northern Research Station, Syracuse, NY) was kind enough to perform repeated UFORE model runs for me and answer my numerous questions. Susan Bagshaw (Executive Assistant), Tammy Baum, (Administrative Coordinator), and Robin Hawkins (Administrative Coordinator) of the Louisville Metro Public Works and Assets Department were instrumental in answering my query about the amount of storm debris collected by the city. Tammy Baum actually calculated and verified the totals. Many thanks to Vernon Smith and Eric Schneider of the Kentucky State Data Center for their help with census data; Eric taught me how to navigate the U.S, Census Department's website and sent spreadsheets with census block group data for 
each of my plots. Vickie Hamilton at the Jefferson County Property Valuation Administrator's office assisted me with housing condition codes. Bruce Carroll, the database contact person at Louisville/Jefferson County Information Consortium (LOJIC) provided the information on the age of the land use layer in the LOJIC database. I extend a huge thank you to my wonderful University of Louisville undergraduate field crew, Hannah Graham Davis, Trey Nunn, and Carrie Wein Scadden. Not only could I not have done it without you, I wouldn't have had nearly as much fun. Dr. Jennifer MansfieldJones was available at the drop of an email to help me in the field in 2009. I would not have made it without my lab mate, Dr. Tara Trammell, who helped me with field and lab work, stats, writing, and so much more. Our coffee shop meetings, your wonderful friendship, and baby therapy (precious William Herschel) helped keep me sane. Thank you to Dr. Sarah Emery and Dr. Lauren Heberle for agreeing to be on my committee. A heartfelt thank you to my husband, Michael, for his love and support throughout. AND OF COURSE, I would not be here without all of the support and assistance from my adviser and mentor, Dr. Margaret Carreiro. Thanks for accepting me into your lab and being there in too many ways to list! And last, but not least, thanks to all of the citizens of Louisville who let me come into their yards to take tree measurements - two summers in a row - and for answering the survey questions. 


\title{
ABSTRACT \\ SPECIES COMPOSITION, DEMOGRAPHICS, AND ECOSYSTEM SERVICES OF RESIDENTIAL TREES IN LOUISVILLE, KENTUCKY
}

\author{
Shannon A. Scroggins
}

March 28, 2011

Trees in urban residential neighborhoods provide valuable ecosystem services. Urban trees also face threats from disturbances, such as storms. In 2008, the Urban Forest Effects model was used to estimate abundance and species composition of residential trees and their ecosystem services in 10 of 26 council districts in Louisville, Kentucky. Ten tree species were found to compose half of the estimated 822,576 residential trees in the ten districts, with Celtis occidentalis being most numerous. The ability of sociodemographic and housing variables to predict the distribution of trees and ecosystem services was weak. The strongest relationships were found between $\%$ single home and $\%$ owner resident and tree number, species richness, and Shannon diversity. After two record-breaking storms in 2008 and 2009 , tree canopy losses were found to be $7.9 \%$ with concomitant decreases in ecosystem services. A survey showed only $33 \%$ of residents intended to replant lost trees. 
TABLE OF CONTENTS

PAGE

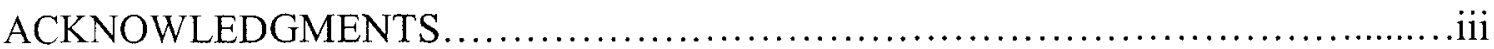

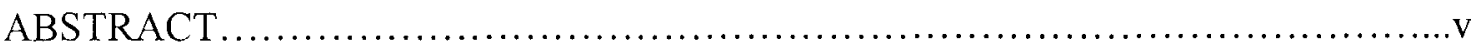

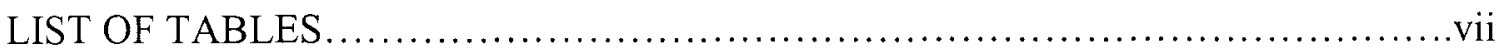

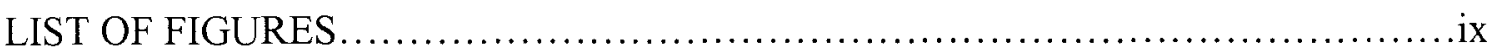

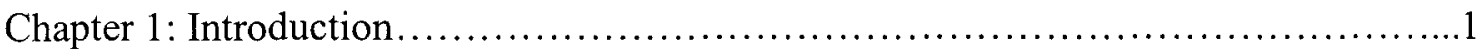

Chapter 2: Variation in tree species abundance and distribution, and their................7 ecosystem services in relation to socio-demographic and housing variables

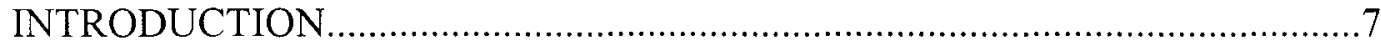

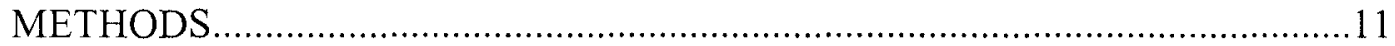

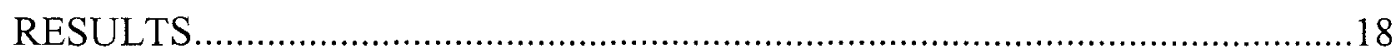

DISCUSSION

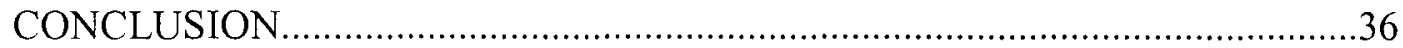

Chapter 3: Effects of two major storms events on residential trees in Louisville, KY.....74

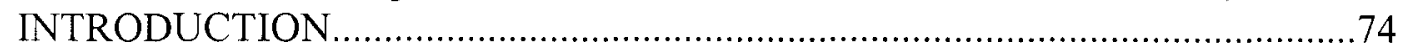

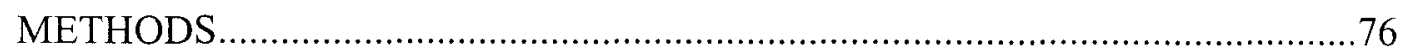

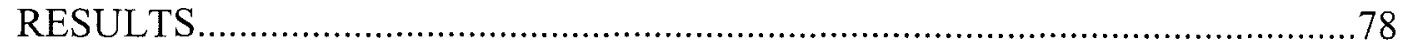

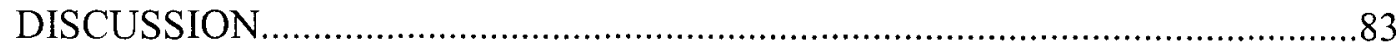

CONCLUSION

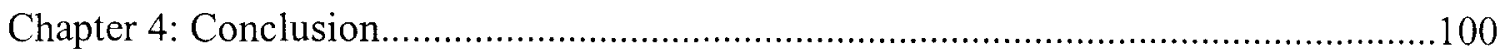

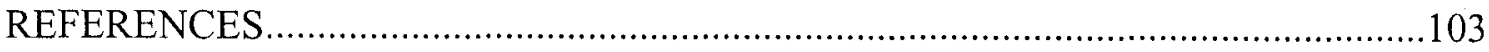

APPENDICES

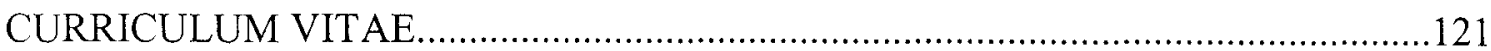




\section{LIST OF TABLES}

TABLE

PAGE

2-1. Socio-demographic and housing variables in 10 council districts.....................39

2-2. Total land area, total residential land area, population, and population density in residential land use in 10 council districts

2-3. Top 10 tree species from 100 UFORE plots in Louisville, KY.

2-4. Species richness and species richness per hectare residential land use in 10 council districts

2-5. Tree species in the largest quartile size class, council where tree found, and native status

2-6. Tree species in the smallest quartile that are also found in the largest quartile....42

2-7. Median tree height and tallest tree in residential areas of 10 council districts......42

2-8. UFORE estimated percent and number of trees in each condition class for residential land areas of 10 council districts.

2-9. Percent plot cover variables by council district with means and standard errors. 44

2-10. Total amount of pollutants removed (metric tons) in the residential areas of 10 council districts.

2-11. Pearson correlation ( $\mathrm{R}$ ) and significance for socio-demographic and housing variables and tree physical attributes at the council district level.

2-12. Pearson correlation ( $\mathrm{R}$ ) and significance for socio-demographic and housing variables and tree physical attributes at the census tract level

2-13. Pearson correlation (R) and significance for socio-demographic and housing variables and tree physical attributes at the census block group level.

2-14. Pearson correlation ( $\mathrm{R}$ ) and significance for socio-demographic and housing variables and tree physical attributes at the plot level. 
2-15. Marginally significant relationships between axis 1 and axis 2 and tree community variables in the residential areas at the council district level

2-16. Pearson correlation (R) and significance for socio-demographic and housing variables and plot cover variables at the council district level

3-1. Survey questions administered to UFORE plot residents.

3-2. UFORE-estimated tree loss by Hurricane Ike and the January 2009 ice storm in 10 Louisville council districts.

3-3. Top 11 tree species in residential areas of 10 council districts in the summer of 2009

3-4. Individual trees lost during Hurricane Ike in September 2008 and/or the ice storm in January 2009

3-5. Individual trees that sustained damage during Hurricane Ike in September 2008 and/or the ice storm in January 2009

3-6. Changes in carbon storage and sequestration from 2008 to 2009 after the loss of trees in Hurricane Ike and the January 2009 ice storm.

3-7. Changes in metric tons of specific and total pollutants removed by trees from 2008 to 2009 .

3-8. Total amount of pollutants removed $(\mathrm{kg})$ in the residential areas of 10 council districts

3-9. Tree storm damage survey information by council district

3-10. Trees listed in storm damage survey as species residents would consider planting as replacement trees after the storms. 


\section{LIST OF FIGURES}

FIGURES

PAGE

1-1. Conceptual model of the relationship between people, trees, and ecosystem services in urban residential areas.

1-2. Conceptual model showing how a storm disturbance affects both urban residents, trees, and ecosystem services.

2-1. Map of Kentucky with Jefferson County highlighted. 52

2-2. Council district map of Louisville-Jefferson County Metro, Kentucky...... .53

2-3. Principal Components Analysis (PCA) showing distribution of 10 council districts used in UFORE study.

2-4. Principal Components Analysis (PCA) showing distribution of 10 council districts along a range of socio-demographic and housing variables....

2-5. Shannon diversity index for trees in residential areas of 10 council districts......56

2-6. UFORE-estimated number of trees $\mathrm{ha}^{-1}$ residential land in 10 council districts.

2-7. $\quad$ DBH $(\mathrm{cm})$ size class by quartiles for trees in residential areas of 10 council districts.

2-8. $\mathrm{DBH}(\mathrm{cm})$ size class range and percent frequency in total residential land areas of 10 council districts.

2-9. Total tree basal area per residential land area (ha) of each of 10 council districts.

2-10. UFORE-estimated total leaf area per council district residential land area..........61

2-11. Total Leaf Area Index (LAI) of residential land area in 10 council districts.......62

2-12. Condition Class of trees in residential land areas of 10 council districts 63

2-13. Plot coverage percentages by council district 
2-14. Number of honeysuckle (Lonicera maackii) shrubs per hectare residential land use in each council district.

2-15. Carbon stored by trees per ha of residential land area in 10 council districts.......66

2-16. Carbon sequestered by trees in the residential land areas of 10 council districts.

2-17. Total pollutants removed annually by trees in residential land areas of 10 council districts.

2-18. Net energy savings in dollars for residential areas of 10 council districts.

2-19. Net total energy savings due to tree shading, windbreak, and climate effects in residential land areas of 10 council districts.

2-20. Net total tons of power plant carbon emissions avoided due to tree effects in residential land area of 10 council districts.

2-21. Percentage of trees susceptible to various insect pests in residential areas of 10 council districts.

2-22. Pearson correlation between axis 2 and Shannon Diversity Index for residential areas of 10 council districts

2-23. Pearson correlation between axis 2 and species richness for residential areas of 10 council districts.

2-24. Pearson correlation between axis 2 and mean number of trees per hectare for residential areas of 10 council districts.

3-1. UFORE-estimated loss in tree value due to storm damage.

3-2. Percent reduction in net energy savings in MWh and in net carbon emissions avoided from fossil-fuel using power plants for residential areas of 10 council districts.

3-3. Percent losses in net energy savings in dollars for residential areas of 10 council districts. 


\section{CHAPTER 1: INTRODUCTION}

Slightly more than $50 \%$ of the world's population (United Nations 2009) and $80 \%$ of the citizens of Europe and North America live in cities (Pickett et al. 2001). The United Nations (2009) predicts that the urban population worldwide will increase to $55.5 \%$ in 2025 and $65.9 \%$ in 2050 . Because of this trend, it is important to study the ecology of cities, which considers the city as an ecosystem in which humans and their individual and institutional behaviors are an integral part of an urban system's ecological dynamics (Wu 2008). Cities use most of the world's resources and create most of its wastes and, because of this, urban areas have ecological footprints approximately 500-1000 times that of their physical area (Folke et al. 1997; Grimm et al. 2008). Since the behavior and decision-making of people and institutions affect these inputs and wastes, it is important to understand how their choices influence not only the immediate urban environment, but contribute to regional and global changes, e.g., increased $\mathrm{CO}_{2}$ emissions from fossilfuel-generated electricity contributing to global climate change (Grimm et al. 2008). Also, because cities are where an increasing majority of people live, it is imperative to understand how cities are structured, as the balance between green and built infrastructure determines urban resilience to stressors and disturbance, and affects the well being of most of the world's people (Dwyer et al. 1992; Costanza et al. 1997; Bolund and Hunhammar 1999). Ecology of cites also emphasizes the importance of 
interdisciplinary collaboration between natural and social scientists and transdisciplinary collaboration among academic scientists, planners, policy makers, managers, engineers, and the public to better understand the interactions between the ecological, social, and built environmental components of the urban ecosystem (Wu 2008).

One important ecological component of a city is its urban forest. The urban forest includes trees in parks, yards, institutional campuses, and along public rights-of-way (Zipperer et al. 1997). Some of the urban forest is under public control (e.g., trees in parks and along public rights-of-way), but trees found in residential yards and on institutional campuses are under the control of private managers. According to Nowak et al. (1996), across the U. S. A. residential land averages $41 \%$ of total city area, so any trees in these areas can make important contributions to total city tree cover and provide important ecosystem services to urban residents. Ecosystem services are the benefits that accrue to humans from properly functioning ecological systems (Costanza et al. 1997). Ecosystem services provided by residential urban trees include decreased energy usage to heat and cool buildings, removal of air pollutants including particulate matter, improved water quality, and decreased stormwater runoff into streams (Ziegler 1973; Rolfe 1974; Heisler 1986; Sanders 1986; Akbari et al. 1992).

Unfortunately, the ecosystem services provided by trees may be inequitably distributed around a city due to low income (Heynen 2006), lack of plantable space, and high percentage of rental properties (Perkins et al. 2004). Such discrepancies result in reduced residential tree canopy cover in low income neighborhoods, which can be considered a form of environmental injustice (Talarchek 1990). Harlan et al. (2008) found that the urban heat island effect was unevenly distributed along income lines in 
Phoenix, AZ and that poor neighborhoods suffered higher summer temperatures than wealthier ones. Since trees in residential neighborhoods can ameliorate some of the negative effects of urbanization, such as the urban heat island (Akbari et al. 1986; Akbari et al. 1990; McPherson 1994), it is important to understand how trees are distributed in urban neighborhoods and whether all of a city's residents are benefiting from their ecosystem services.

There are other reasons besides lack of planting that affect the distribution of ecosystem services provided by trees across a city. Ecosystem service benefits are decreased when residential trees are damaged or lost due to insect pest infestations or disturbances, such as fire, wind events, and ice storms (Rogers 1996). Past and present residential decisions about the number and species of trees to plant influence patterns of damage from such disturbances by affecting the species and age class distribution of trees, amount and spatial patterns of tree cover, and the proportion of canopy vulnerable to particular pests or types of physical disturbances. Trees that fall during storms can also pose hazards to human health and property (Lopes et al. 2007). Because of these interactions between trees and people, it is important to understand urban residents' attitudes toward trees, especially after damaging storms (Duryea 1996), so that means may be found to overcome barriers to tree replacement.

Since residential trees are under private management, residents' opinions about the importance of trees for enjoyment of their property help determine whether trees are replaced after disturbance events. If residents feel trees pose a hazard to people and property, they may choose not to replace storm-downed trees or may even opt to remove trees prophylactically. If tree replacement occurs, it may be with smaller tree species than 
occurred before the storm events. Replacement of trees is also affected by whether a resident can afford the expense, so poor neighborhoods may suffer disproportionately from storm damage loss and face increased environmental injustice from further loss of tree ecosystem services (Talarchek 1990; Heynen 2006; Harlan et al. 2008). The cumulative decisions made by private lot owners over time then determine the composition and distribution patterns of the urban forest in privately owned residential areas. By influencing public perception of tree value, storm disturbances may thus influence the subsequent amount and type of tree canopy gap filling that occurs as the urban forest recovers over time.

\section{Conceptual Framework and Study Goals}

The conceptual model in figure 1-1 shows the relationships between people, trees, and ecosystem services. In residential areas, people make decisions about which tree species to plant, how many trees to plant, and where trees are planted (arrow 1, from people to trees). Trees directly affect people by providing amenities such as beauty, wildlife habitat, and shade (arrow 1, from trees to people). Trees also contribute ecosystem services (arrow 2) such as decreased air pollutants and reduction in energy costs (Ziegler 1973; Rolfe 1974; Heisler 1986; Akbari et al. 1992). Ecosystem services directly benefit people (arrow 3 ) and are themselves indirectly influenced by urban residents' tree management decisions (arrow 1 to trees; arrow 2 to ecosystem services). Chapter 2 reports on a study conducted in the summer of 2008 that used the Urban Forest Effects (UFORE) model developed by the U.S. Forest Service to quantify the community composition, canopy cover, size class distribution, and ecosystem services provided by 
the residential trees in ten of Louisville's council districts. It also explores whether there are any statistically discernible relationships between tree community structure, function, and ecosystem services and a selection of socio-demographic and housing variables that varied among these ten council districts.

The conceptual model in figure 1-2 shows how a storm disturbance directly influences urban residents and the urban forest, and indirectly changes the ecosystem services provided by trees. Storm disturbances directly harm people through injury and property damage (arrow 1) and indirectly cause damage to people and their buildings by toppling trees or breaking branches (arrow 2; arrow 3 to people). Trees are directly affected by storms through non-fatal damage or by being blown over (arrow 2). The decisions that private land-owners subsequently make about the trees in their yards is an indirect effect of the storm on the trees (arrow 1; arrow 3 to trees). Trees that are lost and damaged by the storm lead to a decrease in ecosystem services (arrow 4) and the benefits provided to urban residents (arrow 5). Chapter 3 reports the losses of trees and ecosystem services in the residential areas of ten of Louisville's council districts after the remnants of Hurricane Ike in September 2008 and an ice storm in January 2009 damaged and destroyed many trees across the city. It also provides results of a post-storm survey to investigate urban residents' attitudes toward tree replacement after these two storms. 


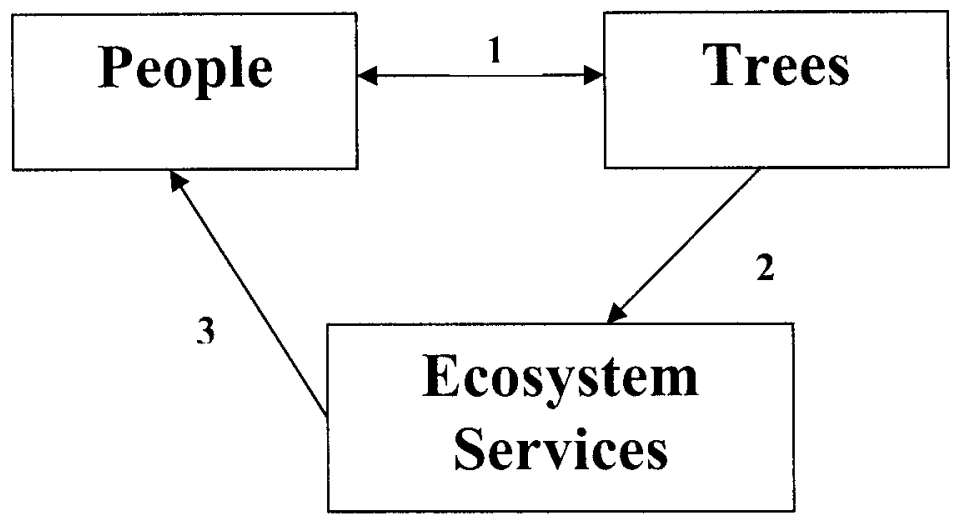

Figure 1-1: Conceptual model of the relationship between people, trees, and ecosystem services in urban residential areas. In nature, tree species populations are affected by soil characteristics, the available species pool, climate, topography, and biotic factors, such as herbivory and mutualistic associations. In urban areas, tree species abundance and distribution are affected by past and present decisions made by residents and municipal decision makers. The structure and function of the residential urban forest determines the ecosystem services that benefit urban residents.

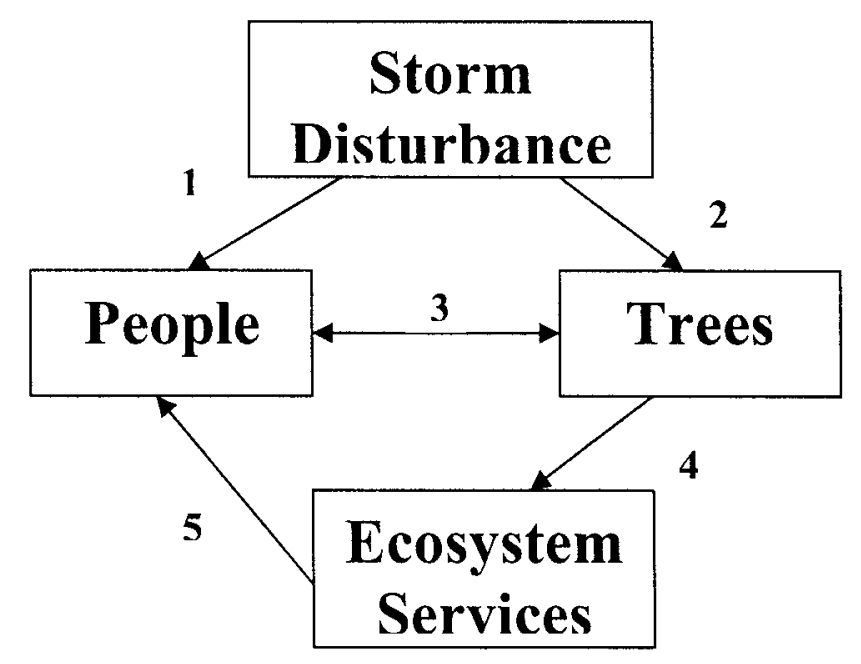

Figure 1-2: Conceptual model showing how a storm disturbance affects both urban residents and trees and indirectly (through trees and people) ecosystem services. 


\section{CHAPTER 2: VARIATION IN TREE SPECIES ABUNDANCE AND DISTRIBUTION, AND THEIR ECOSYSTEM SERVICES IN RESIDENTIAL LAND USE IN RELATION TO SOCIO-DEMOGRAPHIC AND HOUSING VARIABLES}

\section{INTRODUCTION}

Globally, a little over $50 \%$ of humanity lives in urban areas (United Nations 2009) and in the industrialized nations of Europe and North America nearly $80 \%$ of the population already does (Pickett et al. 2001). Increased urbanization has many negative ecological effects from local to global scales. At the global scale, urban areas cover only $2 \%$ of the terrestrial surface of the Earth, but they create $78 \%$ of the greenhouse gases (Grimm et al. 2000). More locally, urban areas are characterized by the urban heat island, where typical daily temperatures in summer average 3 to $5^{\circ} \mathrm{C}$ higher, and can be as much as 8 to $12^{\circ} \mathrm{C}$ warmer at ground level, than nearby rural areas (Hutchison and Taylor 1983; Akbari et al. 1990; Grimmond and Oke 1995; Alberti 2009). This is due to proportion of built surface (vs. green) and the height-to-width ratio of the streets and their adjacent buildings (e.g., urban structure; street canyons) that heat up during the day and release heat at night, heat that remains for longer periods at ground level at night depending on urban structure variables such as the sky-view factor (Hutchison and Taylor 1983; Akbari et al. 1990; Grimmond and Oke 1995; Eliasson 1996; Alberti 2009). Heat stress in cities has become a matter of increasing public health concern (Harlan et al. 2006). 
Warmer city microclimates lead to increased energy use for summer cooling, which leads to increased air pollutant emissions from fossil-fuel burning power plants (Hutchinson and Taylor 1983; Akbari et al. 1990; McPherson 1994). Decreased air quality due to point and non-point sources of pollutants is also a pervasive negative sideeffect of urbanization that can have deleterious effects on human health (Nowak 1994). Among the most important urban air pollutants affecting human health are ozone $\left(\mathrm{O}_{3}\right)$, nitrogen oxides $\left(\mathrm{NO}_{\mathrm{x}}\right)$, sulfur dioxide $\left(\mathrm{SO}_{2}\right)$, and fine particulate matter with a diameter of less than $10 \mu \mathrm{m}\left(\mathrm{PM}_{10}\right)$ (Nowak 1994; Alberti 2009).

Cities also have increased impervious surfaces, such as buildings, roads, and parking lots. These hard surfaces are not only main contributors to the urban heat island effect, but also prevent infiltration of water into the ground, which leads to increased storm runoff, decreased groundwater recharge, local flooding, and flashier stream flows (Sanders 1986; Xiao et al. 1998; Walsh et al. 2005; Nowak and Dwyer 2007). This trend toward greater urbanization increases the importance of studying urban environments to ameliorate their negative environmental impacts, to improve the health of the people living there, and to find ways of preserving native biodiversity in metropolitan areas (Botkin and Beveridge 1997).

Trees are an important natural component of cities that can improve the negative environmental and social effects of urbanization. These urban forest trees include trees along streets, and in yards, institutional campuses, parks, and forest remnants (McPherson et al. 1997). They play an important role in urban areas by providing valuable ecosystem services such as reducing the cost of heating and cooling buildings, decreasing air pollutants and particulate matter, improving water quality, decreasing 
runoff into streams, and improving biodiversity of local wildlife, like birds, that also benefit people (Ziegler 1973; Rolfe 1974; Heisler 1986; Sanders 1986; Akbari et al. 1992; Nowak and Dwyer 2007). By shading buildings in the summer and acting as windbreaks in the winter, trees can reduce the costs - both financial and ecological - of heating and cooling (Akbari et al. 1986; Heisler 1990; Akbari 2002). Trees help remove air pollutants through mechanisms such as dry deposition and particle entrapment (Lovett et al. 2000; Fowler 2002). A 1994 study conducted in Chicago estimated that the city's trees provided air cleaning services worth $\$ 9.2$ million and saved $\$ 50$ to $\$ 90$ per dwelling in yearly heating and cooling costs (McPherson et al. 1997). Urban trees also decrease runoff by intercepting rainfall and by taking up water that infiltrates the soil and releasing it as water vapor into the atmosphere via the process of transpiration (Sanders 1986; Xiao et al. 1998; Bolund and Hunhammar 1999). Both of these processes slow the return of water to streams (Sanders 1986; Nowak and Dwyer 2007). Other social benefits provided by urban forest trees are locations for recreational opportunities, aesthetic pleasure, real estate enhancement, and possibly even crime reduction (Morales, 1980; Smardon 1988; Tyrväinen and Miettinen 2000; Kuo and Sullivan 2001; Tyrväinen et al. 2003; Jim and Chen 2006).

An important component of the urban forest and the focus of this study are trees found in residential areas. Since on average $41 \%$ of total city area is composed of residential land (Nowak 1996), trees in yards and along residential streets can comprise an essential part of the urban tree canopy. Trees in yards provide daily experiences with nature, since they are closest to people (Smardon 1988). They also play a role in increasing neighborhood satisfaction across a broad socio-demographic range (Vemuri et 
al. 2011). Residential trees provide valuable ecosystem services at the levels of the individual lot, the neighborhood, and the city as a whole. (Morales, 1980; Parker 1983; Tyrväinen and Miettinen 2000; Akbari 2002).

Trees found in home lots are for the most part under private control. So when determining the abundance and distribution of trees in residential areas, it is important not only to estimate statistically or inventory the structure of the tree assemblages, but also to obtain information on how the decisions made by private managers affect this resource and the ecosystem services it provides (DeWalle 1978; Heisler 1989). Understanding the motivations behind the decisions made by individual lot owners concerning trees is essential, because tree planting choices affect the biodiversity of the residential forest, the amount of canopy cover in neighborhoods, and how well this tree resource is maintained (Richards 1993; Heynen et al. 2006: Carreiro and Zipperer 2008). However, this private management of the residential urban forest can also create inequities in tree canopy cover and ecosystem service benefits (Talarchek 1990; Escobedo et al. 2006; Heynen et al. 2006). Poor residents may not be able to afford the cost of planting and maintaining trees and, if they rent their home, there is little incentive to plant trees (Perkins et al. 2004; Heynen et al. 2006). Escobedo et al. (2006) determined that greater tree cover, larger leaf area index (LAI), higher tree density, and better tree health were found in higher socioeconomic neighborhoods of Santiago, Chile. These findings have important implications for whether trees and their ecosystem services are provided equitably across social strata (Escobedo et al. 2006; Heynen et al. 2006).

In this study, I explored whether relationships existed between species composition, canopy cover, size-class distribution, health and mortality, and ecosystem services of 
residential trees and socio-demographic and housing stock variables at the council district level (e.g., median income, education level, age of housing stock, percent owner residents). It was hypothesized that this analysis would determine whether such factors might explain the distribution of privately owned trees and their ecosystem services at a scale relevant to political reporting. In addition, I explored whether socio-demographic data collected at two additional smaller spatial scales (census tract, census block group) varied in their ability to predict residential tree distribution and abundance. There were two overarching goals to this project: 1) to quantify the status of the residential urban forest in Louisville, Kentucky, and 2) to attempt to explain differences in tree community attributes and ecosystem service distribution using variations in socio-demographic and housing stock variables at these three spatial scales.

\section{METHODS}

\section{Study Area}

The city of Louisville, founded in 1778, is located in north-central Kentucky along the Ohio River at latitude $38^{\circ} 15^{\prime} 15^{\prime \prime} \mathrm{N}$ and longitude $85^{\circ} 45^{\prime} 34^{\prime \prime} \mathrm{W}$ (http://geonames.usgs./pls/gnispublic/). The city merged with Jefferson County (Figure 21) in 2003 to form the Louisville-Jefferson County Metro Government, so that now the city has a land area of $981 \mathrm{~km}^{2}$ and an estimated 2009 population of 721,594 (http://factfinder.census.gov). The study area is located within the Eastern Broadleaf Forest (Continental) Ecoregion Province (Bailey and Cushwa 1981; http://www.nationalatlas.gov/mld/ecoregp.html) and in the Interior Plateau of the 
Southeastern USA Plains and Eastern Temperate Forest Region [Classified as Region 8.3.3 in the Omernik Ecoregion System, Levels I-III (http://www.nationalatlas.gov/mld/ecoomrp.html)]. The mean annual temperature in Louisville, based on the 30 -year interval between 1970 and 2000 , is $13.8^{\circ} \mathrm{C}$ and ranges from an average monthly temperature of $0.6{ }^{\circ} \mathrm{C}$ in January to an average monthly temperature of $25.8^{\circ} \mathrm{C}$ in July (NCDC 2006). Mean annual precipitation in Louisville is $113 \mathrm{~cm}$, distributed evenly throughout the year (NCDC 2006).

\section{Experimental Design}

The Louisville-Jefferson County Metropolitan Area is divided into 26 council districts (Figure 2-2) that vary in size, but have similar populations (approximately 25,000 people). The decision was made to conduct this study at the council district scale because socio-demographic data were readily available at this scale and because it would facilitate reporting of results at the political scale. Socio-demographic and housing stock data were obtained from the Kentucky State Data Center and were based on U.S. Census 2000 data. Districts were chosen on the basis of having a broad range of differences in sociodemographic and housing stock attributes. Among these attributes were seven chosen for their presumed predictive value based on prior literature (Talarchek 1990; Freedman et al. 1996; Hope et al. 2003; Perkins et al. 2004; Escobedo et al. 2006; Heynen et al. 2006). These were percentage of population with no high school diploma (education), percentage African-American, median income, percentage single-family homes, percentage owner residents, median single home value, and median year built for single homes (Table 2-1). A Principal Components Analysis was performed with these 
variables from all 26 council districts to determine how the districts varied and which of the seven attributes accounted for most of the differences among the districts. Figure 2-3 shows the distribution of the 26 council districts along the first two principal components, which summarized and simplified the attribute data set from the initial seven variables to three principal components in two orthogonal dimensions that explained a total of $86 \%$ of the variation among council districts. Axis 1 accounted for $66 \%$ of the total variation and was best explained by median income and \% owner residents. Axis 2 accounted for $20 \%$ of the total variation and was best explained by $\%$ single family homes. These data and other factors, such as geographic location and prior knowledge of neighborhoods, were used to select the council districts for the study. Ten of these council districts were selected for model building purposes, reserving others for later model validation if funding became available. The total land area of the ten Council Districts in this study was $263 \mathrm{~km}^{2}$ or $26.8 \%$ of county land area. The area of residential land in the ten Council Districts was $129.8 \mathrm{~km}^{2}(13.2 \%$ of county land area; $49.3 \%$ of land area in the ten Council Districts sampled). The council districts used for this study were: council districts 2 and 24 in south-central Jefferson County; 14 and 25 in the southwest; 3 and 5 in the northwest; 7 and 18 in the east; and 8 and 9 near the center (Figure 2-2). These ten council districts also varied in total area, total area of residential land use, and population density (Table 2-2).

The process for selecting plots in each district made use of Geographic Information Systems (GIS; ArcGIS 9.2, ESRI 2006) software to randomly select 40 locations in each of these ten council districts. These locations were randomly numbered and a Louisville/Jefferson County Information Consortium (LOJIC) land-use overlay was used 
to determine which of these locations occurred in the residential land use category. LOJIC provides a database with spatial maps and digitized data layers $(0.3 \mathrm{~m}$ resolution) for all of Jefferson County. The aerial photographs used to make the maps were taken in 2006 and the data used to make the land-use overlay were published in 1992 (Bruce Carroll, Louisville/Jefferson County Information Consortium, personal communication). Residential land use included both single-family and multi-family residential categories. Within the residential land-use areas, 12 to 15 plots per council district were randomly selected, and letters mailed out to each residential address seeking permission to enter property. In total, 231 letters were mailed, 70 returned stating that permission was granted, and 3 returned denying permission. If no answer was obtained, follow-up phone calls or emails were made in the summer of 2008 to residents for whom we had this information. If we had no phone number or email address for a resident of the plot, then we knocked on the door to ask for permission. Ultimately we were able to use ten residential locations in each of ten council districts for this study. For each residential location the GIS coordinates determined randomly provided a central locus for each plot. This locus was buffered with an 11.3 meter radius circle as described in the Urban Forest Effects (UFORE) model protocol (Nowak et al. 2007a). Each circular plot had an area of $404.7 \mathrm{~m}^{2}$.

Plot level measurements

From May to July 2008, data were collected from each plot on tree species composition and size, and other land cover and vegetation attributes according to the Urban Forest Effects (UFORE) model protocol (Nowak et al. 2007a). This protocol uses 
species identification, diameter-at-breast-height (DBH), total tree height, canopy volume, and $\%$ dieback to determine tree species diversity, size-class distribution, tree leaf area index, tree canopy health, and susceptibility to pest attack. These variables are also entered into the model for calculating ecosystem services, such as amount of carbon stored and sequestered annually, pollutants removed per year, and energy use avoided annually (Nowak and Crane 2000; Nowak et al. 2002). For each plot, percentage of tree cover, shrub cover and plantable space were also estimated. Ground cover variables (i.e., $\%$ cement, $\%$ building, $\%$ maintained grass, $\%$ duff $/$ mulch) were also measured. Trees and shrubs were identified to genus and to species when possible using the National Audubon Society Field Guide to Trees: Eastern Region (Little 2006) and the Manual of Woody Landscape Plants (Dirr 1998). For trees that were 6.1 meters tall or more and that were located within 18 meters of buildings that were three-stories tall or less, direction and distance from the tree to the nearest part of the building(s) was measured. These measurements were then modeled in UFORE to estimate annual energy savings at the council district level.

\section{UFORE Analysis}

The Urban Forest Effects (UFORE) Model is a tool developed by the USDA Forest Service that calculates various tree community characteristics for the urban forest. Based on the plot data, UFORE modeling estimates species composition, size-distribution structure, leaf area, health, and pest susceptibility of trees in the urban forest information useful for managing the forest (MacFarlane and Meyer 2005; Nowak and Crane 2000; Nowak et al. 2007a). The model also calculates ecosystem services, such as 
the amount of carbon stored and sequestered, net savings in energy use including both heating and cooling components, and removal of several gaseous and particulate air pollutants (e.g., NOx gases, $\mathrm{O}_{3}, \mathrm{PM}_{10}$ ) by tree canopies (Nowak and Crane, 2000; Nowak et al. 2002, Nowak et al. 2007a). It also measures disservices of trees (sensu Pataki et al. 2011), such as production of volatile organic carbon compounds and pollen. In addition, the model estimates a monetary value estimate for the non-commodity, replacement value of a tree based on valuation procedures of the Council of Tree and Landscape Appraisers (1992); (Nowak and Crane 2000; Nowak et al. 2002, Nowak et al. 2007a).

\section{Data and Statistical Analysis}

The data collected in the summer of 2008 were sent to the USDA Forest Service office in Syracuse, NY, since they alone can process the data using the UFORE model software. The resulting modeled data were then used to provide estimates on the following tree characteristics for each council district and for all ten districts combined: tree species composition, tree number, basal area, leaf area coverage and leaf area index, and ecosystem services distribution. Relationships between tree community attributes, as well as ecosystem service data, and the socio-demographic and housing variables at the council district level were explored for statistical significance using bivariate analysis consisting of Pearson correlation and linear regression in Microsoft Excel 2002. Principal Components Analysis (PCA) using PC-ORD v 4.25 was conducted to explore covariation among the socio-demographic and housing variables at the council district level (Figure 2-4). Principal Components Analysis is an ordination technique that collapses and simplifies multiple variables into a set of fewer composite variables (McCune and Grace 
2002). The first two or three of these composite variables usually explain most of the covariation among the variables or components (McCune and Grace 2002). The seven socio-demographic and housing variables used in our PCA were: \% African-American, \% no high school diploma, median income, $\%$ owner resident, $\%$ single home, median house value, and median age of house in 2008. The resultant PCA axis coordinates for each council district were used as potential predictors of tree community characteristics using Pearson correlation and linear regression (Microsoft Excel 2002). Pearson correlation and linear regression (Microsoft Excel 2002) were also used to determine if any relationships existed between the coordinates for each council district along the explanatory axes and plantable space, tree, and shrub cover, and impervious surface cover ( $\%$ cement, $\%$ tar, $\%$ building). We also explored whether socio-demographic and housing variables acquired at the census tract and other smaller scales provided greater power to explain variation in tree community characteristics.

\section{Analyses at smaller spatial scales}

Pearson correlation and linear regression (Microsoft Excel 2002) was used to explore relationships between tree community attributes, as well as ecosystem service data, and the socio-demographic and housing variables at the plot, census block group, and census tract levels. The 100 UFORE plots were located in 80 census block groups and 53 census tracts. At the plot level, only house age and value from the Property Valuation Administrator (PVA) of Jefferson County, Kentucky were possible to obtain via their website (http://jeffersonpva.ky.gov/). The socio-demographic and housing 
variable data at the census block group and census tract level were obtained from the U.S. Census Bureau, American Fact Finder website (http://factfinder.census.gov).

In addition, Nonmetric Multidimensional Scaling (NMDS) analysis was conducted with PC-ORD v. 4.25 to determine whether variation in species abundance (based on basal area data) was predictable using plot, census block group, and census tract scale data and their respective socio-demographic and housing stock variables as available for these scales. Species were included in the matrix if they occurred in more than one plot, census block group, or census tract, depending on the scale of the analysis. NMDS was run in autopilot mode on the slow and thorough setting with the default parameters of a Sørensen (Bray-Curtis) distance measure, a random starting configuration, 40 runs with real data, and 50 randomized runs. The runs with real data used the species basal area matrices, while the randomized runs shuffled the data within columns in these matrices (McCune and Grace 2002).

\section{RESULTS}

\section{Characteristics and Ecosystem Services of Residential Tree Communities in}

\section{Louisville}

Tree Species Composition and Diversity

A total of 264 trees $(\mathrm{DBH}>2.54 \mathrm{~cm})$ of 64 species in 37 genera and in 21 families were identified in 71 of the 100 UFORE plots (Appendix Table 1); 29 of the plots did not contain any trees. The majority of the tree species found were native to Kentucky 
(69.4\%) and native to North America (74.7\%). Of the non-native tree species in the plots, $10.4 \%$ were native to Asia, $4.1 \%$ to Eurasia, $2.5 \%$ to Europe, and $8.3 \%$ unknown. Evergreen trees constituted $16.7 \%$ of the total sampled trees and coniferous evergreen trees made up $14.8 \%$ of the total. The most common tree species encountered was Celtis occidentalis L. (Northern Hackberry) and it constituted $11 \%$ of the total number of trees encountered. Fifty percent of the trees encountered in residential land consisted of only ten species (Table 2-3). Overall, the Shannon diversity index calculated based on tree number for residential areas of all ten council districts was 3.7 and community evenness score was 0.89 . The evenness score of 0.89 indicates a high level of evenness in the residential tree community of the ten council districts, since community evenness ranges from 0 (only one species present) to 1 (all species are present in equal amounts). The maximum Shannon diversity index possible for a community is equal to the natural log of the total species richness and increases with higher species richness and higher evenness. The maximum Shannon index for a community of 64 is equal to $4.16[\operatorname{Ln}(64)]$. Therefore, the index we obtained of 3.7 is reflective of a highly even community. Species richness per council district ranged from 6 to 22 with a mean of $13.3 \pm$ SE 1.7 per council district (Table 2-4). Tree family richness per council district ranged from 6 to 14 with a mean of $8.6 \pm \mathrm{SE} 1.0$ per council district. The Shannon diversity index ranged from 1.7 to 2.8 per district with a mean Shannon diversity index per council district of $2.33 \pm \mathrm{SE}$ 1.33 (Figure 2-5).

Physical and Ecosystem Level Attributes of Trees 
The UFORE model estimated that there were a total of 822,576 trees in residential land in the 10 council districts. On a per area residential land basis, estimated tree density ranged from 22.2 to 116.1 trees $^{-1} \mathrm{a}^{-1}$ with a mean of 65.2 trees ha ${ }^{-1} \pm \mathrm{SE} 9.9$ (Figure 2-6). Council district 14 had the lowest tree density and council district 9 the highest.

Mean diameter-at-breast height $(\mathrm{DBH})$ for trees in the residential areas of the 10 council districts was $31.3 \mathrm{~cm}$ with a median value of $23 \mathrm{~cm}$. Council district 14 had the largest mean $\mathrm{DBH}$ in the tree population with a mean $\mathrm{DBH}$ of $53.6 \mathrm{~cm}$ and median of $51.8 \mathrm{~cm}$. Trees with the smallest mean $(19.5 \mathrm{~cm})$ and median $(15 \mathrm{~cm}) \mathrm{DBH}$ were found in council district 9 (Figures 2-7 and Appendix Figure 1). The size-class distribution of the tree community across all ten council districts was skewed toward smaller trees, with $59 \%$ of the trees in residential areas in the lowest quartile DBH range $(2.5$ to $30.5 \mathrm{~cm})$, $25 \%$ in the second quartile $(30.6$ to $61.0 \mathrm{~cm}), 13 \%$ in the third quartile $(61.1$ to $91.4 \mathrm{~cm})$ and the remaining $3 \%$ in the highest quartile $(91.5$ to $129.5 \mathrm{~cm}$ ) (Figure 2-8). All of the trees in the largest quartile were species native to the state (Table 2-5). The largest species found in each of the represented council districts varied, except in council districts 3 and 14 where the largest trees were both Quercus palustris Muench (Pin Oak) (Table 2-5). In the smallest DBH quartile (2.5-30.5cm DBH), only $15 \%$ of the inventoried trees were the same species as those in the largest quartile, and $87.5 \%$ of these smallest quartile trees were all the same species, $C$. occidentalis (Table 2-6). There were no individuals of Quercus velutina Lam. (Black Oak) found in the smallest quartile and only one each of Acer saccharinum L. (Silver or Water Maple), Fraxinus americana L. (White Ash), and Q. palustris (Table 2-6). Council districts 2, 5, 7, 9, and 18 had no 
inventoried trees in the largest DBH quartile. Of the council districts that did have trees in the largest quartile $(91.5-129.5 \mathrm{~cm} \mathrm{DBH})$, council district 24 had the most per residential land at $0.0081 \mathrm{ha}^{-1}$ and council district 25 had the fewest at $0.0030 \mathrm{ha}^{-1}$. The species richness of the smallest quartile diameter class was 53 and the most abundant species was C. occidentalis, with 21 individuals or $13.2 \%$ of the total. In the largest quartile, the species richness was 5 and the most abundant species was $A$. saccharinum. Tree basal area $\mathrm{ha}^{-1}$ residential land in each council district varied from a low of $14.2 \mathrm{~cm}^{2} \mathrm{ha}^{-1}$ in council district 14 to a high of $50.3 \mathrm{~cm}^{2} \mathrm{ha}^{-1}$ in council 8 (Figure 2-9). The mean basal area across all ten districts was $28.9 \mathrm{~cm}^{2} \mathrm{ha}^{-1} \pm \mathrm{SE} 3.7$.

The median tree height across all council districts was $10.6 \mathrm{~m}$. The largest median tree height of $25.9 \mathrm{~m}$ was found in council district 14 and the smallest in council district 9 at $7.3 \mathrm{~m}$ (Table 2-7). UFORE-estimated leaf area $\mathrm{ha}^{-1}$ residential land in each council district ranged from $8,933 \mathrm{~m}^{2} \mathrm{ha}^{-1}$ (council district 14) to $29,272 \mathrm{~m}^{2} \mathrm{ha}^{-1}$ (council district 2) (Figure 2-10). The Leaf Area Index (LAI, or area of leaves per area of land and therefore a unit-less ratio) was also calculated for each council district. LAI in ecology is used as an index of primary production in many ecosystems and can also reflect the amount of potential shading and surfaces for transpirational water loss and air cooling as well as air pollutant capture in residential areas. LAI was calculated for each council district based on the mean leaf area values reported above and the area of residential land in each council district, and for the entire ten council districts. The total LAI range was 0.89- 2.93 with a mean of $1.71 \pm 0.22 \mathrm{SE}$ (Figure 2-11). Council district 14 had the lowest LAI of 0.89 and council district 2 the highest 2.93 . 
UFORE calculated that $59.2 \%$ of the trees across all ten council districts were in excellent condition, $33.6 \%$ in good condition, $6.6 \%$ in fair condition, and $0.5 \%$ were dead (Table 2-8). Figure 2-12 shows tree conditions for all ten council districts. The replacement value of the trees in each council district ranged from $\$ 169,683 \mathrm{ha}^{-1}$ in council district 5 to $\$ 562,196 \mathrm{ha}^{-1}$ in council district 2 .

For each plot, percentage tree cover, shrub cover, and plantable space were estimated. Percent plantable space ranged from 13 in council district 9 to 51.5 in council district 14 with a mean of $26.5 \pm 3.8 \mathrm{SE}$ (Figure 2-13). Tree cover percentage was lowest in council district 14 (15.8) and highest in council district 7 (45.1). The mean percent tree cover across the ten council districts was $30.3 \pm 3.2 \mathrm{SE}$ (Figure 2-13). Ground cover variables (i.e., $\%$ cement, $\%$ building, $\%$ maintained grass, $\%$ duff $/$ mulch) were also measured. For the ground cover variables, percentage cement, tar, and building were combined to create a percent impervious surface cover variable. Percent impervious surface cover was highest in council district $5(62.9 \%)$ and lowest in council district 25 $(26.6 \%)$ with a mean of $41.3 \% \pm 3.6$ SE (Table $2-9)$. Council district 25 had the highest percent grass coverage at $65.3 \%$ and council district 5 the lowest at $15.8 \%$ (Table $2-9$ ). The mean across all ten council districts for percent grass cover was $38.4 \% \pm 4.1 \mathrm{SE}$.

The exotic shrub, Lonicera maackii (Rupr.) Maxim. (Amur Honeysuckle), is of great interest in the Louisville area due to its invasion of urban parks and woodlands. In the initial UFORE survey, we included L. maackii in the inventory if it had a DBH of $2.5 \mathrm{~cm}$ or greater. This shrub was encountered in six of the ten council districts and its estimated density ranged from 0 to 51.9 shrubs ha ${ }^{-1}$ residential land, with a mean of 9.1 shrubs ha ${ }^{-1}$ \pm SE 5.1 across the ten council districts (Figure 2-14). L. maackii was found in $10 \%$ of 
the plots in districts $2,3,18$, and 25 , and $20 \%$ of the plots in districts 8 and 9. Of the council districts where L. maackii was found, council district 3 had the lowest density at 2.5 shrubs ha ${ }^{-1}$ residential land and district 8 had the highest at 51.9 shrubs ha $^{-1}$ residential land.

\section{Ecosystem Services}

\section{Carbon Storage and Sequestration}

Carbon storage and sequestration values are estimated for combined above- and below-ground tree carbon. Estimated tree carbon storage for residential land across the ten council districts ranged from 16,712 to $48,649 \mathrm{~kg} \mathrm{ha}^{-1}$ with a mean of $31,292 \mathrm{~kg} \mathrm{ha}^{-1} \pm$

$\mathrm{SE} 3,521$ and carbon sequestration ranged from 623 to $1,485 \mathrm{~kg} \mathrm{ha}^{-1}$ residential land $\mathrm{yr}^{-1}$ with a mean of $1,102 \mathrm{~kg} \mathrm{ha}^{-1} \mathrm{yr}^{-1} \pm 101 \mathrm{SE}$. Council district 5 had the lowest tree carbon storage and sequestration values and council district 2 had the highest (Figures 2-15 and 2-16). The tree species that stored the most carbon in the council districts were $A$. saccharinum with $14.9 \%$ of the total, Acer saccharum Marsh. (Sugar Maple) $12.2 \%$, and Q. palustris $11.1 \%$. A. saccharum, A. saccharinum, and C. occidentalis sequestered the most carbon at $11.7 \%, 10.8 \%$, and $10.1 \%$ of the total, respectively. All of these tree species are native to Kentucky.

\section{UFORE Air Pollutant Removal}

The UFORE model calculated that a total of 465 metric tons (mt) of air pollutants are removed annually by trees from the residential areas of the ten council districts. The estimated monetary value of this ecosystem service was $\$ 3,402,825$ and is based on the 
median positive externality conversion values for avoidance of health problems (monetary reduction in health costs per ton of pollutant removed) due to amount of reduction in each of the pollutants by trees (Murray et al. 1994; Nowak et al. 2002). Residential trees across all ten districts removed $229 \mathrm{mt}$ of ozone $\left(\mathrm{O}_{3}\right), 136 \mathrm{mt}$ of $\mathrm{PM}_{10}$, $55.4 \mathrm{mt}$ of sulfur dioxide gas $\left(\mathrm{SO}_{2}\right), 43.9 \mathrm{mt}$ of nitrogen dioxide gas $\left(\mathrm{NO}_{2}\right)$, and $2.4 \mathrm{mt}$ of carbon monoxide gas (CO). Since total leaf area is used to calculate pollutant removal, amounts removed per council district are directly related to the area of residential land and the amount of leaf area per area of residential land. Council district 7 had the highest estimated total pollutant removal at $506 \mathrm{mt}$ and council district 5 had the lowest at $67 \mathrm{mt}$ (Table 2-10). On a per hectare of residential land basis, the range of total pollutants removed across council districts was 94.9 to $311 \mathrm{~kg} \mathrm{ha}^{-1}$ (mean $182 \mathrm{~kg} \mathrm{ha}^{-1} \pm 23.3 \mathrm{SE}$ ), with council district 14 removing the least and council district 2 the most (Figure 2-17).

\section{UFORE Energy Savings}

Net energy use avoided due to tree shading and/or windbreak effects in the residential areas of the ten council districts was estimated to be $30,983 \mathrm{MWh}$. The council district with the highest net annual energy savings (savings from heating in winter and cooling in summer) was council district 7 with 7,879 MWh of energy use avoided. Council district 14 had the lowest savings with 1,140 MWh. The 2008 Louisville Gas and Electric (LG\&E) rate of $\$ 0.064 \mathrm{kWh}^{-1}$ was used to determine money saved due to decreased energy use and a net total of $\$ 1,982,912$ was saved in residential areas of the ten council districts due to tree cover (Figure 2-18). Council district 7 realized the greatest savings at $\$ 504,256$ and council district 14 the lowest at $\$ 72,960$. On a per area basis, the range of 
energy savings was 0.67 to $4.51 \mathrm{MWh} \mathrm{ha}^{-1}$ across the residential land areas of the ten council districts. The mean energy savings on a per area basis was $2.39 \mathrm{MWh} \mathrm{ha}^{-1} \pm 0.36$ SE (Figure 2-19). Council district 14 had the lowest savings and council district 7 had the highest.

The UFORE model also calculated carbon emissions avoided from coal-fired power plants in metric tons of carbon due to reduced energy production load on power plants. The services provided by residential trees in the ten council districts led to a total decrease of 8,926 mt of carbon emissions from Louisville's coal-fired power plants. The trees in council district 7 created the greatest savings of 3,268 $\mathrm{mt}$ of carbon, while trees in council district 8 provided the lowest at $62 \mathrm{mt}$ of carbon. Metric tons of carbon emissions avoided from power plants on a per area basis ranged from 0.06 (council district 8 ) to 1.85 (council district 7) $\mathrm{mt} \mathrm{ha}^{-1}$ residential land area with a mean of $0.62 \mathrm{mt} \mathrm{ha}^{-1} \pm 0.18$ SE (Figure 2-20).

\section{$\underline{\text { UFORE Pollen Misery Index }}$}

While trees provide many benefits to society, trees also create disservices that must be accounted for in a cost-benefit analysis. Allergenic pollen production is one such disservice, but varies by tree species. Pollen allergy potential, as expressed by a pollen misery index, was calculated by UFORE for the trees in each council district, with a value of 10 being the worst for allergy sufferers (Bob Hoehn, USDA Forest Service Technician, personal communication). UFORE uses the Ogren Pollen Allergic Scale rating for each tree species to determine how much leaf area falls into each misery index category (Hoehn, pers. comm.). The mean pollen misery index across all residential areas 
sampled was 6.91. The mean indices for the council districts ranged from 5.69 (council district 7) to 7.8 (council district 25).

\section{Relationships Between Tree Species Abundance and Distribution and Socio- demographic and Housing Variables}

A Principal Components Analysis (PCA) was conducted to explore co-variation among the socio-demographic and housing variables at the council district level. The seven socio-demographic and housing variables used were: $\%$ African-American, $\%$ no high school diploma, median income, $\%$ owner resident, $\%$ single home, median house value, and median age of house in 2008. Results of this PCA revealed that the first three principal component axes explained $96.2 \%$ of the variation among the council districts (PCA1: 56.6\%; PCA2: 29.2\%; PCA3: 10.4\%). Axis 1 (56.6\% of the variation was explained by this axis) consisted of the following variables (with their respective eigenvector values) and could be summarized as the education-income axis: $\%$ no high school diploma (-0.4837), median house value (0.4805), and median income (0.4754); axis $2(29.2 \%$ of the variation was explained by this axis) was explained by $\%$ owner resident $(-0.6538)$ and $\%$ single home $(-0.5158)$; and axis $3(10.4 \%$ of the variation was explained by this axis) was explained by median age of house in $2008(-0.8768)$. This establishes that, indeed, the council districts did vary strongly in their sociodemographics and in the type and value of their housing stock. These factors have been shown in other cities to explain variation in urban tree canopy coverage. For example, higher income neighborhoods in Santiago, Chile were found to have greater tree cover (Escobedo et al. 2006), median income and urban tree cover were found to be positively 
related in Indianapolis, IN (Heynen 2006), and canopy cover was found to decrease with increasing rates of rentership in Milwaukee, WI (Heynen et al. 2006).

To determine if this was the case in Louisville, this study used linear regressions to determine whether the PCA axis coordinates for council districts obtained above and single variables averaged at four spatial scales (council district, census tract, census block group, and plot) correlated with variation in tree data. Surprisingly, these analyses found that the socio-demographic and housing variables had the greatest explanatory value at the largest scale (the council district), and became progressively less tightly related at finer scales of resolution. The highest significant $(\mathrm{p}<0.05) \mathrm{R}$-value for an explanatory variable obtained for each scale was: council district (Table 2-11): - 0.71 (PCA axis 2 and Shannon Index tree diversity; census tract (Table $2-12):-0.38(\%$ single homes and mean leaf area); census block group (Table 2-13): 0.33 (median house value and mean number of trees); and plot (Table 2-14): 0.24 (house value and number of trees). At the council district level, there was a trend for PCA axis $2(\%$ single homes and $\%$ owner residents) to have the strongest, significant $(p<0.05)$ relationships with some of the tree community variables (Table 2-15). Pearson correlation and linear regression were used to explore relationships between the socio-demographic and housing variables and percentage plantable space, tree cover, and shrub cover. PCA axis 2 was significantly correlated with percent plantable space $(R=0.88 ; p<0.01)$ and percent shrub cover $(R=-0.63 ; p<0.05)$ (Table 2-16).

The NMDS analysis that was run to determine whether there was variation in tree species (based on basal area data) between the council district socio-demographic and housing stock variables did not achieve satisfactory results at any of the scales explored 
(plot, census block group, census tract). Too many zeros in the matrices was the reason for the lack of resolution at the plot level (Bruce McCune, personal communication, email). Since all of the matrices contained between $91-96 \%$ zeros for a particular species, this is the most likely explanation for the unsatisfactory results at the census block group and census tract levels as well. A new matrix at the plot level was made by collapsing the tree species to the genus level and only including genera that occurred in more than one plot, but this trial also did not resolve. NMDS analysis did not appear to be suitable for determining patterns at the residential land use level in our plots. Too many of our UFORE plots either had no trees (29 of 100 plots) or only 1 tree, which led to matrices dominated by zeros.

\section{DISCUSSION}

Many studies have been done using UFORE at the city-wide level, for example in Brooklyn (Nowak et al. 2002), Philadelphia (Nowak et al 2007b), San Francisco (Nowak et al 2007c), and New York (Nowak et al. 2007d), which included a sub-set of plots in multi-family and 1-2 family residential areas. In our study, we chose to restrict our plot selection to only residential land use. Unlike trees found in parks or along public rightsof-way, the residential component of the urban forest is under private management. Therefore, sociological and economic factors, past and present, are expected to influence lot-level and neighborhood level tree canopy cover and species composition. Because of this, it would be important for urban forest managers to know if the structure and function of the residential forest can be predicted by socio-demographic and housing stock 
variables, and to know if there are inequitable distributions of ecosystem services provided by trees to different neighborhoods.

In summer of 2008 , Louisville had an estimated 822,576 trees in the residential areas of the ten council districts, which equated to a mean of 65.2 trees ha ${ }^{-1}$ and $30 \%$ tree cover for residential areas. By comparison to other UFORE studies, Brooklyn, NY had 220,000 trees (58.1 trees $^{-1}$ ) and 17\% tree cover in its residential areas (Nowak et al. 2002). These lower values are probably due to the fact that Brooklyn is so much more densely populated and, therefore, has much less plantable space than Louisville, KY. Other cities on the east coast with UFORE data included Philadelphia, PA with 550,000 trees (110.1 trees $\mathrm{ha}^{-1}$ ) in residential areas (Nowak et al. 2007b) and New York City with 1.5 million trees $\left(54.3\right.$ trees $\mathrm{ha}^{-1}$ ) in residential areas (Nowak et al. 2007d). On the west coast, San Francisco, CA was estimated to have 210,000 trees $\left(51.9\right.$ trees $\left.^{-1} \mathrm{a}^{-1}\right)$ in residential areas (Nowak et al. 2007c). In all three of these cities, percent tree cover values were only available at the city-wide scale, so were not included herein for comparison. It is difficult to compare the composition of the residential urban forest between cities without knowing the size-class (i.e., DBH) distribution of the trees in residential areas. This information was available for Brooklyn, NY, where the smallest $\mathrm{DBH}$ quartile in residential land areas constituted $57.3 \%$ of the total compared to Louisville at $59.2 \%$ (Nowak et al. 2002), so percentage of trees in the smallest quartile was similar for both these cities. For the other three cities, DBH size-class data were only available at the citywide level.

Further comparisons can be made with cities that were not part of a UFORE study. Hefei, China, west of Shanghai, was found to have a residential tree density of 153 trees 
$\mathrm{ha}^{-1}$ (Wu et al. 2008). A breakdown by neighborhood age or other characteristics was not reported by Wu et al. (2008) for Hefei's residential areas, but was in the following study. Freedman et al. (1996) stratified tree data by neighborhood age and found that residential tree cover in older neighborhoods ( $>70$ years old) of Halifax, Nova Scotia had tree densities of 145.1 trees $\mathrm{ha}^{-1}$, middle-aged neighborhoods (40-50 years old) had tree densities of 158.0 trees ha $^{-1}$, and younger neighborhoods ( $<8$ years old) had tree densities of 240.9 trees $\mathrm{ha}^{-1}$. Louisville's older neighborhoods ( $>70$ years old) had higher tree densities with a mean of 86.5 trees $\mathrm{ha}^{-1}$, than the middle-aged neighborhoods (40-50 years old) with a mean of 65.1 trees $\mathrm{ha}^{-1}$, the opposite of the trend found in Nova Scotia (Freedman et al. 1996). Freedman et al. (1996) also reported that the trees in the older neighborhoods in Halifax were larger than those in the younger neighborhoods, which helped account for the differences in density. In Louisville's oldest districts, we found that an average of $69.7 \%$ of the trees were in the smallest DBH class quartile (2.5$30.5 \mathrm{~cm})$ and only $1.8 \%$ in the largest quartile $(91.5-129.5 \mathrm{~cm})$. While in the middle-aged neighborhoods, we found that an average of $57.4 \%$ of the trees were in the smallest DBH class quartile and $5.6 \%$ in the largest. Louisville's older neighborhoods have a higher tree density, most likely due to a greater number of trees in the smallest DBH quartile, than its middle-aged neighborhoods, the opposite of what Freedman et al. (1996) found in their study. This may be because Louisville's older neighborhoods have lost their older, larger trees due to attrition from disease and death in the past. We didn't have young neighborhoods to compare with this study, since no council districts had a median home age less than 43 years in 2008 . 
Insect pests are a threat to the health of the urban residential forest. Susceptibility to insect pests was estimated by UFORE and it was found that $51.1 \%$ of the trees in the residential areas of the ten council districts were susceptible to the Asian longhorned beetle, which preferentially attacks maples (Haack et al. 1997); $16.6 \%$ were susceptible to the gypsy moth caterpillar, which attacks primarily oaks (Jones et al. 1998); and 4.6\% were susceptible to the emerald ash borer, which attacks ashes (MacFarlane and Meyer 2005). Pest susceptibility in the residential areas of the ten council districts ranged from: 27.5 to $81.3 \%$ for the Asian longhorned beetle; 3.6 to $52.5 \%$ for the gypsy moth caterpillar; and 0 to $27.3 \%$ for the emerald ash borer (Figure 2-21). If the Asian longhorned beetle migrated to Louisville, KY it would have devastating effects on the trees in residential areas and the ecosystem services they provide with $51 \%$ of the residential canopy vulnerable across the ten council districts. Council districts 24,18 , and 3 would be the hardest hit by the Asian longhorned beetle with $81.3 \%, 71.1 \%$, and $66.5 \%$ of their canopies vulnerable, respectively. Council district 8 faces a two-fold threat with $45.3 \%$ of its canopy vulnerable to the Asian longhorned beetle and $27.3 \%$ to the emerald ash borer. A gypsy moth caterpillar infestation would cause the most harm in council districts 25 (52.5\% of canopy vulnerable) and 14 (49.2\% of canopy vulnerable).

Louisville's residential trees (ten council districts) stored $32.0 \mathrm{mt}$ of carbon $\mathrm{ha}^{-1}$ and sequestered $1.04 \mathrm{mt}$ of carbon $\mathrm{ha}^{-1} \mathrm{yr}^{-1}$. This was approximately twice the carbon stored and sequestered by trees on a per area basis in the other four comparison cities. Brooklyn's residential trees stored 17.6 metric tons of carbon $\mathrm{ha}^{-1}$ and sequestered 0.7 metric tons of carbon $\mathrm{ha}^{-1} \mathrm{yr}^{-1}$ (Nowak et al. 2002). For the other three cities, carbon 
storage and sequestration figures were only available city-wide, so direct residential landuse level comparisons were not possible

The UFORE model estimates three components for heat energy usage avoided windbreak, shade, and climate - and two components for cooling energy usage avoided shade and climate (Nowak et al. 2007a). Windbreak calculates megawatt hour (MWh) usage avoided for heating due to trees blocking wind (Nowak et al. 2007a). Shade calculates MWh usage avoided for cooling due to tree shade (Nowak et al. 2007a). Shade values for heat energy usage avoided are usually negative, indicating that tree shading increases the energy used to heat a home (Heisler 1986; McPherson and Simpson 1999). Climate calculates the impact on residential space heating and cooling provided by faraway trees due to reduction in wind speed and the cooling effect provided by the tree cover (Akbari et al. 1986). I combined all of these components to get the net energy savings provided by trees in the residential areas of the ten council districts and then compared this figure to city-wide figures for two of the four comparison cities for which the information was available. The residential trees in Louisville provided a net energy savings of $30,983 \mathrm{MWh}$, while the trees near residential buildings in Philadelphia provided a net energy savings of $28,600 \mathrm{MWh}$, and those in New York city, 81,000 MWh (Nowak et al. 2007b; Nowak et al. 2007d). On a per area basis, Louisville's residential trees are providing a net energy savings of $239 \mathrm{MWh} \mathrm{km}^{2}$, while Philadelphia's urban

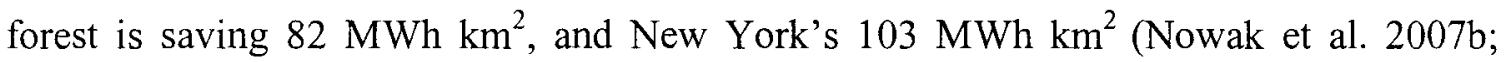
Nowak et al. 2007d). Louisville's per area energy savings may be higher than Philadelphia's and New York's, because we only sampled residential land use and did not include industrial sites or the core urban business district, which often have fewer trees 
than residential areas (Nowak et al. 1996). For example, New York City's commercial/industrial areas had 12.3 trees $\mathrm{ha}^{-1}$, whereas Louisville's residential areas in the ten council districts had 65.2 trees $\mathrm{ha}^{-1}$. Also, residential homes are not as tall as buildings in business districts and, therefore, receive a greater benefit from tree shading in the summer. So, the values calculated for Louisville's residential areas indicate greater energy savings per tree for this reason.

Trees also reduce the amount of carbon emissions from coal-fired power plants in metric tons of carbon due to reduced energy production load on the power plant (Nowak 1993; Nowak et al. 2007a). Net carbon emissions avoided by the residential trees in the ten Louisville districts amounted to $8,926 \mathrm{mt}\left(69 \mathrm{mt} \mathrm{km}^{2}\right)$. The city-wide net carbon emissions avoided for Philadelphia were $698 \mathrm{mt}$ of carbon $\left(2 \mathrm{mt} \mathrm{km}^{2}\right)$ and for New York City, 8,254 metric tons of carbon $\left(10.5 \mathrm{mt} \mathrm{km}^{2}\right.$ ) (Nowak et al. 2007b; Nowak et al. 2007d). As stated in the above paragraph, by sampling only residential land use, our study shows higher values for tree canopy than city-wide values for reasons such as smaller building size as compared to a downtown business district and greater tree cover due to less impervious surface.

UFORE also estimates the pollutant removal services provided by tree canopies. Louisville's residential trees removed 465 metric tons of pollutants annually. The values for Brooklyn, Philadelphia, San Francisco, and New York City were all city-wide estimates. So, they are not directly comparable. On a per area basis, Louisville's residential trees remove more pollutants than all of the other cities: $3.6 \mathrm{mt} \mathrm{km}^{2}$ compared to $1.4 \mathrm{mt} \mathrm{km}^{2}$ annually for Brooklyn, $2.0 \mathrm{mt} \mathrm{km}^{2}$ for San Francisco annually, $2.5 \mathrm{mt} \mathrm{km}^{2}$ annually for New York, and $2.1 \mathrm{mt} \mathrm{km}^{2}$ annually for Philadelphia (Nowak et al. 2002; 
Nowak et al. 2007b; Nowak et al. 2007c; Nowak et al. 2007d). One possible explanation for this is that we have greater leaf area $\mathrm{km}^{-2}$ in our residential areas than the other cities do, since they did their studies on a city-wide basis.

In this study, the UFORE model was successful in providing data on the status of the residential urban forest in Louisville, KY. We also explored the extent to which sociodemographic and housing variable differences at three scales (council district, census tract, and census block group) might explain variation in tree community attributes. At the council district level, we did find negative trends between diversity, species richness, and mean number of trees, and PCA axis 2 variables ( $\%$ single homes; \% owner residents) (Figures 2-22, 2-23, and 2-24) but relationships at smaller scales were weaker. We concluded that to improve correlations with socio-demographic and housing variables at all scales, we would need more information at the entire house lot level. The 0.04 ha UFORE plot was perhaps too small to capture enough information about tree populations managed by lot owners at a site to adequately explore potential relationships between socio-demographic and housing variables and tree community and ecosystem service data.

However, other studies have found relationships between socio-demographic and housing variables and plant diversity. Hope et al. (2003) examined potential relationships between perennial plant diversity in the Central Arizona-Phoenix region where suburban sprawl has been rapid in the last two decades, and three socio-demographic and housing variables: median family income, median age of housing stock, and human population density. They found that non-woody plant diversity in urban areas was positively related to higher incomes $(\mathrm{p}<0.01)$ and newer housing stock $(\mathrm{p}<0.01)$. We might have expected 
to also see positive relationships between median income, median age of housing stock, and population density with species richness in our plots, but this did not turn out to be the case. All correlations between these variables and species richness were nonsignificant. This may be due to the fact that unlike Hope et al. (2003), we examined woody (tree) plant diversity, which is often more a reflection of past home owners' preferences (Whitney and Adams 1980). Older neighborhoods may also have seen shifts in affluence: what may have been a middle-class neighborhood 50 to 100 years ago may now be a poor neighborhood (Whitney and Adams 1980). So, past tree choices and species richness may not coincide with the council districts current median income. Nonetheless, In our study we did find a statistically significant negative correlation at the council district level (Figure 2-23) between PCA Axis 2 variables (\% single homes; \% owner residents) and species richness $(\mathrm{R}=-0.64 ; \mathrm{p}<0.05)$. The correlation at the council district level between species richness and axis 1 variables (\% no high school diploma; median income; median house value) was positive, but marginally significant $(\mathrm{R}=0.59$; $\mathrm{p}=0.07)($ Table 2-15).

Heynen (2006) investigated how changes in income were related to changes between 1962 and 1993 in urban tree cover at the census tract level in Indianapolis, Indiana. He found that the residential urban canopy cover in that time period significantly $(\alpha=0.05)$ decreased by $23.1 \%$ and that neighborhoods that had lower income had less tree cover. As expected at the census tract level in our study, there was a significant $(\mathrm{p}<0.05)$ positive correlation between median income and mean number of trees, but the Pearson R-value was low at 0.27 , suggesting that other factors also affect tree density in Louisville's residential areas (Table 2-12). At the council district level, we found a 
strong, but statistically marginal, $(\mathrm{p}=0.06)$ positive correlation (Pearson $\mathrm{R}=0.62$ ) between PCA Axis 1 ( $\%$ no high school diploma; median income; median house value) and mean number of trees, which deserves further examination (Table 2-15). The negative correlation between mean number of trees and the PCA Axis 2 variables (\% single homes; $\%$ owner residents $)$ at the council district level was significant $(R=-0.65$; $\mathrm{p}<0.05$ ) (Figure 2-24). As stated earlier, in this study there was a tighter fit between tree variables and socio-demographic and housing data at the council district level than at the smaller census tract level.

A significant but weak $(\alpha=0.01$, Spearman $r=-0.320)$ negative relationship between renters and residential canopy cover and a significant, weak $(\alpha=0.01$ Spearman $r=$ 0.178) positive relationship between median income and residential canopy cover was found in Milwaukee, WI (Perkins et al. 2004). Tree cover and tree density were also found to be higher in neighborhoods with greater income in Santiago, Chile (Escobedo et al. 2006). In our study, the relationship between median income and percent residential tree cover were positively related, but not statistically significant $(p=0.39)$. The relationship between $\%$ owner resident and tree cover in Louisville, KY had a negative trend, the opposite of what Perkins et al. (2004) found, but it was also insignificant ( $\mathrm{p}=$ $0.23)$.

\section{CONCLUSION}

This study provides information on the species composition, abundance, health, and ecosystem services provided by Louisville's residential forest and can provide a foundation for more detailed studies in the future. Given that the area of many cities is 
mostly residential, residential trees are an important component of the urban forest and provide valuable ecosystem services at the house, neighborhood, and whole city scales for urban residents, such as energy savings, carbon storage and sequestration, and pollutant removal. The trees in the residential areas of the ten council districts in our study provided comparable ecosystem services to other cities in which UFORE studies have been done. Since the residential component of the urban forest is almost exclusively under private management, it is important to understand the attitudes of residents toward trees (see chapter 3) and to determine how we can educate the general public about the importance of trees and the ecosystem services they provide.

To further understand the relationship between residential trees and the ecosystem services they provide, it would be valuable to ascertain what, if any, relationships exist between socio-demographic and housing variables and tree community and ecosystem service data. Since the quantitative goals for relating socio-demographics to urban residential tree cover were inconclusive in this study, we cannot make any statements concerning how environmental justice in the distribution of ecosystem services provided by trees may be linked with poorer communities in this city. However, our data may still be helpful in informing priorities for urban forest management to alleviate tree cover and ecosystem service inequities. One possible approach to help mitigate this type of environmental injustice would be for the city to conduct an inventory of right-of-way trees in residential areas with low tree cover, low income, and plantable space to determine if there are feasible locations along these rights-of-way for increasing residential tree cover. City managers might also subsidize tree planting services to residents who have space and interest in planting trees. Ideally, the trees would be 
delivered to homes, since poor residents might be dependent on public transportation, which would make transporting a tree difficult (Perkins et al. 2004). A tree planting program in poor, underserved neighborhoods might also need to make provision for watering newly planted trees and maintaining them as they mature.

As mentioned previously, this study did not demonstrate any strong relationships between tree community characteristics or ecosystem service variables and sociodemographic and housing variables at finer scales, such as at the census tract or census block group level, but we did find a few stronger significant correlations at the council district level. The strengths of the UFORE model are that it relates tree data to ecosystem service estimates and extrapolates data from the plot level to the entire residential land area of the ten council districts used in this study. What did not work as well was determining relationships between these data and socio-demographic and housing variables. UFORE plots are randomly placed and can land on rooftops and in streets, as well as in yards. In order to better capture what is going on at the yard level and find relationships between residential tree characteristics and census block group and census tract data, entire individual lot level (as opposed to the UFORE plot level) data need to be acquired. By capturing more information at the lot owner level and increasing sample size (number of lots), we increase the probability of obtaining stronger correlations with socio-demographic and housing stock variables at the census tract or census block group levels. 
Table 2-1: Socio-demographic and housing variable values in the 10 council districts used for the UFORE study

\begin{tabular}{|l|c|c|c|c|c|c|c|c|c|c|}
\hline & $\mathbf{2}$ & $\mathbf{3}$ & $\mathbf{5}$ & $\mathbf{7}$ & $\mathbf{8}$ & $\mathbf{9}$ & $\mathbf{1 4}$ & $\mathbf{1 8}$ & $\mathbf{2 4}$ & $\mathbf{2 5}$ \\
\hline $\begin{array}{l}\text { \% African- } \\
\text { American }\end{array}$ & 52 & 57 & 62 & 3 & 6 & 7 & 3 & 5 & 6 & 3 \\
\hline $\begin{array}{l}\text { \% No High } \\
\text { School } \\
\text { Diploma }\end{array}$ & 15 & 19 & 22 & 5 & 6 & 8 & 16 & 5 & 15 & 13 \\
\hline $\begin{array}{l}\text { Median } \\
\text { Income } \\
\text { (\$1000's) }\end{array}$ & 29.3 & 29.9 & 24.5 & 52.1 & 44.0 & 37.9 & 39.7 & 58.6 & 40.3 & 43.5 \\
\hline $\begin{array}{l}\text { \% Single } \\
\text { Homes }\end{array}$ & 60 & 81 & 87 & 66 & 56 & 58 & 95 & 61 & 79 & 76 \\
\hline $\begin{array}{l}\text { \% Owner } \\
\text { Residents }\end{array}$ & 48 & 65 & 54 & 66 & 58 & 53 & 79 & 66 & 69 & 70 \\
\hline $\begin{array}{l}\text { Single } \\
\text { Home } \\
\text { Median } \\
\text { Year Built }\end{array}$ & 1952 & 1944 & 1888 & 1949 & 1881 & 1933 & 1950 & 1965 & 1957 & 1958 \\
\hline $\begin{array}{l}\text { Median } \\
\text { Single } \\
\text { Home } \\
\text { Value } \\
\text { \$1000's }\end{array}$ & 75.9 & 73.6 & 54.1 & 149.1 & 146.2 & 132.6 & 83.1 & 167.5 & 89.7 & 98.1 \\
\hline
\end{tabular}


Table 2-2: Total land area, total area of residential land use, population, and population density in residential land use in 10 council districts in Louisville, KY.

\begin{tabular}{|c|c|c|c|c|}
\hline $\begin{array}{c}\text { Council } \\
\text { District }\end{array}$ & $\begin{array}{c}\text { Total Area } \\
\left.\mathbf{( k m}^{\mathbf{2}}\right)\end{array}$ & $\begin{array}{c}\text { Total Area of } \\
\text { Residential } \\
\text { Land } \mathbf{( k m}^{\mathbf{2}}\end{array}$ & $\begin{array}{c}\text { Population } \\
(\mathbf{2 0 0 0} \text { Census) }\end{array}$ & $\begin{array}{c}\text { Population Density } \\
\text { in Residential Land } \\
\text { per } \mathbf{k m}^{\mathbf{2}}\end{array}$ \\
\hline $\mathbf{2}$ & 22.8 & 10.9 & 26,114 & 2,405 \\
\hline $\mathbf{3}$ & 17.8 & 9.8 & 26,835 & 2,750 \\
\hline $\mathbf{5}$ & 19.4 & 6.5 & 26,333 & 4,077 \\
\hline $\mathbf{7}$ & 26.6 & 17.5 & 25,758 & 1,475 \\
\hline $\mathbf{8}$ & 13.3 & 9.6 & 27,983 & 2,901 \\
\hline $\mathbf{9}$ & 26.6 & 11.3 & 27,233 & 2,405 \\
\hline $\mathbf{1 4}$ & 58.0 & 17.1 & 25,689 & 1,499 \\
\hline $\mathbf{1 8}$ & 28.2 & 14.5 & 24,519 & 1,691 \\
\hline $\mathbf{2 4}$ & 38.9 & 13.9 & 26,649 & 1,923 \\
\hline $\mathbf{2 5}$ & 33.3 & 18.7 & 26,632 & 1,423 \\
\hline
\end{tabular}


Table 2-3: Top 10 tree species from 100 UFORE plots in Louisville, KY.

\begin{tabular}{|l|c|c|c|}
\hline \multicolumn{1}{|c|}{ Species } & Family & $\begin{array}{c}\text { Individual } \\
\text { Frequency }\end{array}$ & $\begin{array}{c}\text { Cumulative } \\
\text { Frequency } \\
\text { Percent }\end{array}$ \\
\hline Celtis occidentalis & Ulmaceae & 29 & 11.0 \\
\hline Acer saccharum & Aceraceae & 16 & 17.0 \\
\hline Acer saccharinum & Aceraceae & 15 & 22.7 \\
\hline Cercis canadensis & Fabaceae & 12 & 27.3 \\
\hline Cornus florida & Cornaceae & 11 & 31.4 \\
\hline Morus rubra & Moraceae & 11 & 35.6 \\
\hline Malus species ${ }^{\text {a, e }}$ & Rosaceae & 9 & 39.0 \\
\hline Acer negundo & Aceraceae & 9 & 42.4 \\
\hline Fraxinus pennsylvanica & Oleaceae & 9 & 45.8 \\
\hline Morus alba & Moraceae & 9 & 49.2 \\
\hline & & & \\
\hline Fraxinus americana** & Oleaceae & $(3)$ & 50.4 \\
\hline & & & \\
\hline Sum & & $\mathbf{1 3 3}$ & \\
\hline Total of 64 Sampled & & $\mathbf{2 6 4}$ & $\mathbf{1 0 0 . 0}$ \\
\hline Species & & & \\
\hline
\end{tabular}

${ }^{\mathrm{a}}$ Malus sp. = Crab Apples

${ }^{\mathrm{e}}$ exotic species

**Note: $F$. americana is not the $11^{\text {th }}$ most common tree; it is included due to Emerald Ash Borer susceptibility

Table 2-4: Species Richness and species richness per hectare residential land use in 10 council districts

\begin{tabular}{|r|c|c|}
\hline $\begin{array}{l}\text { Council } \\
\text { District }\end{array}$ & $\begin{array}{c}\text { Number } \\
\text { of } \\
\text { Species }\end{array}$ & $\begin{array}{c}\text { Tree Species ha } \\
\text { Residential Land } \\
\text { Reside }\end{array}$ \\
\hline $\mathbf{2}$ & 12 & 0.0111 \\
\hline $\mathbf{3}$ & 12 & 0.0123 \\
\hline $\mathbf{5}$ & 11 & 0.0170 \\
\hline $\mathbf{7}$ & 14 & 0.0080 \\
\hline $\mathbf{8}$ & 19 & 0.0197 \\
\hline $\mathbf{9}$ & 20 & 0.0177 \\
\hline $\mathbf{1 4}$ & 6 & 0.0035 \\
\hline $\mathbf{1 8}$ & 22 & 0.0152 \\
\hline $\mathbf{2 4}$ & 6 & 0.0043 \\
\hline $\mathbf{2 5}$ & 11 & 0.0059 \\
\hline
\end{tabular}


Table 2-5: Tree species in the largest quartile size class $(91.5-129.5 \mathrm{~cm})$, council district where tree found, and native status.

\begin{tabular}{|l|r|r|r|}
\hline \multicolumn{1}{|c|}{ Species } & $\begin{array}{c}\text { DBH } \\
\text { (cm) }\end{array}$ & \multicolumn{1}{c|}{$\begin{array}{c}\text { Council } \\
\text { District }\end{array}$} & Native? \\
\hline Quercus palustris & 126 & 3 & Yes \\
\hline Celtis occidentalis & 107.4 & 8 & Yes \\
\hline Fraxinus americana & 109.7 & 8 & Yes \\
\hline Quercus palustris & 94.5 & 14 & Yes \\
\hline Acer saccharinum & 108 & 24 & Yes \\
\hline Acer saccharinum & 94.6 & 24 & Yes \\
\hline Quercus velutina & 92.7 & 25 & Yes \\
\hline
\end{tabular}

Table: 2-6: Tree species in the smallest quartile (2.5$30.5 \mathrm{~cm}$ ) that are also found in the largest quartile $(91.5-129.5 \mathrm{~cm})$

\begin{tabular}{|l|r|r|}
\hline Species & \multicolumn{1}{|c|}{$\begin{array}{c}\text { DBH range } \\
\text { (cm) }\end{array}$} & $\begin{array}{c}\text { Number } \\
\text { Found }\end{array}$ \\
\hline Acer saccharinum & 2.8 & 1 \\
\hline Celtis occidentalis & $2.5-26.9$ & 1 \\
\hline Fraxinus americana & 28.2 & 1 \\
\hline Quercus palustris & 30.5 & 0 \\
\hline Quercus velutina & N/A & \\
\hline
\end{tabular}

Table 2-7: Median tree height and tallest tree in residential areas of 10 council districts

\begin{tabular}{|c|c|c|}
\hline $\begin{array}{c}\text { Council } \\
\text { District }\end{array}$ & Median Tree Height $(\mathbf{m})$ & Tallest Tree (m) \\
\hline $\mathbf{2}$ & 22.7 & 36.6 \\
\hline $\mathbf{3}$ & 8.6 & 32 \\
\hline $\mathbf{5}$ & 12.2 & 22.9 \\
\hline $\mathbf{7}$ & 15.8 & 25 \\
\hline $\mathbf{8}$ & 8.5 & 33.5 \\
\hline $\mathbf{9}$ & 7.3 & 29.6 \\
\hline $\mathbf{1 4}$ & 25.9 & 34.1 \\
\hline $\mathbf{1 8}$ & 8.5 & 19.8 \\
\hline $\mathbf{2 4}$ & 14.1 & 24.2 \\
\hline $\mathbf{2 5}$ & 9.1 & 33.2 \\
\hline
\end{tabular}


Table 2-8: UFORE estimated percent and number of trees in each condition class for residential land areas of 10 council districts.

\begin{tabular}{|l|r|r|}
\hline $\begin{array}{c}\text { Condition } \\
\text { Class }\end{array}$ & $\begin{array}{c}\text { Trees in } \\
\text { Condition } \\
\text { Class (\%) }\end{array}$ & $\begin{array}{c}\text { Number of Trees in } \\
\text { Condition Class }\end{array}$ \\
\hline Excellent & 59.2 & 486,965 \\
\hline Good & 33.6 & 276,386 \\
\hline Fair & 6.6 & 54,290 \\
\hline Poor & 0 & 0 \\
\hline Dead & 0.5 & 4,113 \\
\hline
\end{tabular}


Table 2-9: Percent plot cover variables by council district with means and standard errors.

\begin{tabular}{|c|r|r|r|r|r|r|r|r|}
\hline $\begin{array}{c}\text { Council } \\
\text { District }\end{array}$ & $\begin{array}{c}\text { Impervious } \\
\text { Surface } \\
\text { Cover }\end{array}$ & $\begin{array}{c}\text { \% } \\
\text { Grass }\end{array}$ & $\begin{array}{c}\text { \% } \\
\text { Wild } \\
\text { Grass }\end{array}$ & $\begin{array}{c}\text { \% } \\
\text { Herbaceous/Ivy }\end{array}$ & $\begin{array}{c}\text { \% } \\
\text { Duff/Mulch }\end{array}$ & $\begin{array}{c}\text { \% } \\
\text { Rock }\end{array}$ & $\begin{array}{c}\text { \% } \\
\text { Bare } \\
\text { Soil }\end{array}$ & $\begin{array}{c}\text { \% } \\
\text { Water }\end{array}$ \\
\hline $\mathbf{2}$ & 41 & 38.6 & 6.4 & 5.2 & 1.5 & 1.5 & 5.8 & 0 \\
\hline $\mathbf{3}$ & 52.9 & 39 & 0 & 1.2 & 1.8 & 1.6 & 2.3 & 1.3 \\
\hline $\mathbf{5}$ & 62.9 & 15.8 & 2.7 & 8.0 & 2.2 & 6.1 & 2.3 & 0 \\
\hline $\mathbf{7}$ & 43 & 44.7 & 0 & 2.8 & 1.9 & 2.2 & 5.4 & 0 \\
\hline $\mathbf{8}$ & 46.3 & 27.8 & 1.6 & 12.7 & 3.2 & 1.9 & 6.6 & 0.1 \\
\hline $\mathbf{9}$ & 40.9 & 36.2 & 0 & 10.2 & 4.4 & 1.4 & 5.4 & 1.5 \\
\hline $\mathbf{1 4}$ & 29.3 & 33.8 & 26.1 & 7.5 & 0 & 0.2 & 2.0 & 1.1 \\
\hline $\mathbf{1 8}$ & 41.3 & 34.3 & 0.5 & 11.4 & 5.4 & 1.9 & 3.8 & 1.5 \\
\hline $\mathbf{2 4}$ & 29.1 & 48 & 5.2 & 9.1 & 1.6 & 2.6 & 1.4 & 3.0 \\
\hline $\mathbf{2 5}$ & 26.6 & 65.3 & 0 & 2.0 & 1.2 & 2.4 & 1.4 & 1.2 \\
\hline Mean & 41.3 & 38.4 & 4.3 & 7.0 & 2.3 & 2.2 & 3.6 & 1.0 \\
\hline SE & 3.6 & 4.1 & 2.5 & 1.3 & 0.5 & 0.5 & 0.6 & 0.3 \\
\hline
\end{tabular}


Table 2-10: Total amount of pollutants removed (metric tons) in the residential areas of 10 council districts. Range: $67-506 \mathrm{mt}$; mean 236 \pm SE 38.

\begin{tabular}{|c|r|}
\hline $\begin{array}{c}\text { Council } \\
\text { District }\end{array}$ & $\begin{array}{c}\text { Total Pollutants } \\
\text { Removed (mt) }\end{array}$ \\
\hline $\mathbf{2}$ & 338 \\
\hline $\mathbf{3}$ & 138 \\
\hline $\mathbf{5}$ & 67 \\
\hline $\mathbf{7}$ & 506 \\
\hline $\mathbf{8}$ & 208 \\
\hline $\mathbf{9}$ & 231 \\
\hline $\mathbf{1 4}$ & 163 \\
\hline $\mathbf{1 8}$ & 216 \\
\hline $\mathbf{2 4}$ & 250 \\
\hline $\mathbf{2 5}$ & 246 \\
\hline
\end{tabular}


Table 2-11: Pearson correlation (R) and significance for sociodemographic and housing variables and tree physical attributes at the council district level.

\begin{tabular}{|c|c|c|c|}
\hline \multicolumn{4}{|c|}{ Council District } \\
\hline $\mathbf{x}$ & $\mathbf{y}$ & $\mathbf{R}$ & $\mathbf{p}$ \\
\hline Median House Age & Basal Area (mean) & 0.01 & n.s. \\
\hline Axis 1 & Basal Area (mean) & 0.31 & n.s. \\
\hline Axis 2 & Basal Area (mean) & -0.32 & n.s. \\
\hline Axis 3 & Basal Area (mean) & 0.13 & n.s. \\
\hline Median House Age & $\mathrm{DBH}$ (mean) & 0.07 & n.s. \\
\hline Axis 1 & DBH (mean) & 0.08 & n.s. \\
\hline Axis 2 & DBH (mean) & 0.01 & n.s. \\
\hline Axis 3 & DBH (mean) & 0.05 & n.s. \\
\hline Median House Age & DBH (median) & -0.32 & n.s. \\
\hline Axis 1 & DBH (median) & -0.11 & n.s. \\
\hline Axis 2 & DBH (median) & 0.37 & n.s. \\
\hline Axis 3 & DBH (median) & 0.18 & n.s. \\
\hline Median House Age & Leaf Area (mean) & 0.09 & n.s. \\
\hline Axis 1 & Leaf Area (mean) & 0.32 & n.s. \\
\hline Axis 2 & Leaf Area (mean) & -0.55 & n.s. \\
\hline Axis 3 & Leaf Area (mean) & 0.42 & n.s. \\
\hline Median House Age & Tree Height (mean) & 0.03 & n.s. \\
\hline Axis 1 & Tree Height (mean) & 0.03 & n.s. \\
\hline Axis 2 & Tree Height (mean) & -0.22 & n.s. \\
\hline Axis 3 & Tree Height (mean) & 0.03 & n.s. \\
\hline Median House Age & Tree Height (median) & -0.26 & n.s. \\
\hline Axis 1 & Tree Height (median) & -0.25 & n.s. \\
\hline Axis 2 & Tree Height (median) & 0.35 & n.s. \\
\hline Axis 3 & Tree Height (median) & 0.16 & n.s. \\
\hline Median House Age & Carbon Storage (mean) & 0.05 & n.s. \\
\hline Axis 1 & Carbon Storage (mean) & 0.14 & n.s. \\
\hline Axis 2 & Carbon Storage (mean) & -0.18 & n.s. \\
\hline Axis 3 & Carbon Storage (mean) & 0.16 & n.s. \\
\hline Axis 1 & Tree Value (mean) & 0.06 & n.s. \\
\hline Axis 2 & Tree Value (mean) & 0.11 & n.s. \\
\hline Axis 3 & Tree Value (mean) & 0.17 & n.s. \\
\hline Axis 1 & Number of Trees (mean) & 0.62 & n.s. \\
\hline Axis 2 & Number of Trees (mean) & -0.65 & $*$ \\
\hline Axis 3 & Number of Trees (mean) & 0.01 & n.s. \\
\hline Axis 1 & Species Richness & 0.59 & n.s. \\
\hline Axis 2 & Species Richness & -0.64 & $*$ \\
\hline Axis 3 & Species Richness & 0.01 & n.s. \\
\hline Axis 1 & Non-Native Sp. Richness & 0.42 & n.s. \\
\hline Axis 2 & Non-Native Sp. Richness & -0.35 & n.s. \\
\hline
\end{tabular}




\begin{tabular}{|l|l|r|c|} 
Axis 3 & Non-Native Sp. Richness & 0.13 & n.s. \\
\hline Axis 1 & Diversity & 0.52 & n.s. \\
\hline Axis 2 & Diversity & -0.71 & $*$ \\
\hline Axis 3 & Diversity & 0.05 & n.s. \\
\hline Axis 1 & Energy Savings (MWh) & 0.49 & n.s. \\
\hline Axis 2 & Energy Savings (MWh) & -0.34 & n.s. \\
\hline Axis 3 & Energy Savings (MWh) & 0.22 & n.s. \\
\hline Axis 1 & Energy Savings (tC) & 0.59 & n.s. \\
\hline Axis 2 & Energy Savings (tC) & 0.04 & n.s. \\
\hline Axis 3 & Energy Savings (tC) & 0.24 & n.s. \\
\hline
\end{tabular}

$* \mathrm{p}<0.05$

n.s. = non-significant 
Table 2-12: Pearson correlation (R) and significance for sociodemographic and housing variables and tree physical attributes at the census tract level.

\begin{tabular}{|c|c|c|c|}
\hline \multicolumn{4}{|c|}{ Census Tract } \\
\hline $\mathbf{x}$ & $\mathbf{y}$ & $\mathbf{R}$ & $\mathbf{p}$ \\
\hline Median House Age & Basal Area (mean) & 0.14 & n.s. \\
\hline$\%$ Single Home & Basal Area (mean) & -0.26 & n.s. \\
\hline$\%$ Owner Resident & Basal Area (mean) & -0.18 & n.s. \\
\hline Median House Age & DBH (mean) & -0.15 & n.s. \\
\hline$\%$ Single Home & DBH (mean) & -0.25 & n.s. \\
\hline$\%$ Owner Resident & DBH (mean) & -0.19 & n.s. \\
\hline Median House Age & Leaf Area (mean) & 0.16 & n.s. \\
\hline$\%$ Single Home & Leaf Area (mean) & -0.38 & $* *$ \\
\hline$\%$ Owner Resident & Leaf Area (mean) & -0.34 & $*$ \\
\hline Median House Age & Tree Height (mean) & 0.11 & n.s. \\
\hline$\%$ Single Home & Tree Height (mean) & -0.34 & $*$ \\
\hline$\%$ Owner Resident & Tree Height (mean) & -0.29 & $*$ \\
\hline Median House Age & Carbon Storage (mean) & 0.14 & n.s. \\
\hline$\%$ Single Home & Carbon Storage (mean) & -0.25 & n.s. \\
\hline$\%$ Owner Resident & Carbon Storage (mean) & -0.19 & n.s. \\
\hline Median House Age & Tree Value (mean) & 0.13 & n.s. \\
\hline Median House Value & Tree Value (mean) & 0.03 & n.s. \\
\hline Median Income & Tree Value (mean) & 0.01 & n.s. \\
\hline$\%$ Single Home & Tree Value (mean) & -0.27 & n.s. \\
\hline$\%$ Owner Resident & Tree Value (mean) & -0.23 & n.s. \\
\hline Median House Age & Number of Trees (mean) & 0.08 & n.s. \\
\hline Median House Value & Number of Trees (mean) & 0.32 & $*$ \\
\hline Median Income & Number of Trees (mean) & 0.27 & $*$ \\
\hline$\%$ Single Home & Number of Trees (mean) & -0.33 & $*$ \\
\hline$\%$ Owner Resident & Number of Trees (mean) & -0.17 & n.s. \\
\hline
\end{tabular}


Table 2-13: Pearson correlation (R) and significance for sociodemographic and housing variables and tree physical attributes at the census block group level.

\begin{tabular}{|c|c|c|c|}
\hline \multicolumn{4}{|c|}{ Block Group } \\
\hline $\mathbf{x}$ & $\mathbf{y}$ & $\mathbf{R}$ & $\mathbf{p}$ \\
\hline Median House Age & Basal Area (mean) & 0.03 & n.s. \\
\hline$\%$ Single Home & Basal Area (mean) & 0.16 & n.s. \\
\hline$\%$ Owner Resident & Basal Area (mean) & 0.12 & n.s. \\
\hline Median House Age & DBH (mean) & 0.02 & n.s. \\
\hline$\%$ Single Home & DBH (mean) & -0.18 & n.s. \\
\hline$\%$ Owner Resident & $\mathrm{DBH}$ (mean) & -0.15 & n.s. \\
\hline Median House Age & Leaf Area (mean) & 0.08 & n.s. \\
\hline$\%$ Single Home & Leaf Area (mean) & -0.26 & $*$ \\
\hline$\%$ Owner Resident & Leaf Area (mean) & -0.23 & * \\
\hline Median House Age & Tree Height (mean) & 0.005 & n.s. \\
\hline$\%$ Single Home & Tree Height (mean) & -0.24 & $*$ \\
\hline$\%$ Owner Resident & Tree Height (mean) & -0.21 & n.s. \\
\hline Median House Age & Carbon Storage (mean) & 0.06 & n.s. \\
\hline$\%$ Single Home & Carbon Storage (mean) & 0.18 & n.s. \\
\hline$\%$ Owner Resident & Carbon Storage (mean) & 0.13 & n.s. \\
\hline Median House Age & Tree Value (mean) & 0.06 & n.s. \\
\hline Median House Value & Tree Value (mean) & 0.04 & n.s. \\
\hline Median Income & Tree Value (mean) & 0.01 & n.s. \\
\hline$\%$ Single Home & Tree Value (mean) & -0.24 & $*$ \\
\hline$\%$ Owner Resident & Tree Value (mean) & -0.18 & n.s. \\
\hline Median House Age & Number of Trees (mean) & 0.04 & n.s. \\
\hline Median House Value & Number of Trees (mean) & 0.33 & $* *$ \\
\hline Median Income & Number of Trees (mean) & 0.21 & n.s. \\
\hline$\%$ Single Home & Number of Trees (mean) & -0.16 & n.s. \\
\hline$\%$ Owner Resident & Number of Trees (mean) & -0.23 & n.s. \\
\hline
\end{tabular}


Table 2-14: Pearson correlation (R) and significance for sociodemographic and housing variables and tree physical attributes at the plot level.

\begin{tabular}{|c|c|c|c|}
\hline \multicolumn{4}{|c|}{ Plot } \\
\hline$x$ & $\mathbf{y}$ & $\mathbf{R}$ & p \\
\hline PVA House Age & Basal Area & 0.16 & n.s. \\
\hline PVA House Age & Basal Area: Largest Tree & 0.13 & n.s. \\
\hline PVA House Age & $\mathrm{DBH}$ & 0.15 & n.s. \\
\hline PVA House Age & DBH (no zeros) & 0.12 & n.s. \\
\hline PVA House Age & Leaf Area & 0.15 & n.s. \\
\hline PVA House Age & Tree Height & 0.15 & n.s. \\
\hline PVA House Age & Carbon Storage & 0.14 & n.s. \\
\hline PVA House Age & Tree Value & 0.13 & n.s. \\
\hline PVA House Value & Tree Value & 0.01 & n.s. \\
\hline Median Income & Tree Value & 0.05 & n.s. \\
\hline PVA House Age & Number of Trees & 0.10 & n.s. \\
\hline PVA House Value & Number of Trees & 0.24 & $*$ \\
\hline Median Income & Number of Trees & 0.17 & n.s. \\
\hline PVA House Age & Species Richness & 0.05 & n.s. \\
\hline PVA House Value & Species Richness & 0.24 & $*$ \\
\hline Median Income & Species Richness & 0.14 & n.s. \\
\hline PVA House Age & Non-Native Sp. Richness & 0.01 & n.s. \\
\hline PVA House Value & Non-Native Sp. Richness & 0.13 & n.s. \\
\hline Median Income & Non-Native Sp. Richness & 0.21 & * \\
\hline
\end{tabular}

$* \mathrm{p}<0.05$

n.s. $=$ non-significant 
Table 2-15: Marginally significant relationships between axis 1 (median income, median house age, and \% no high school diploma) and axis $2(\%$ single homes and $\%$ owner residents) and tree community variables in the residential areas at the council district level

\begin{tabular}{|c|l|r|r|}
\hline $\mathbf{x}$ & \multicolumn{1}{|c|}{$\mathbf{y}$} & $\mathbf{R}$ & $\mathbf{p}$ \\
\hline Axis 1 & Mean Number of Trees & 0.62 & 0.06 \\
\hline Axis 1 & Carbon Emissions Avoided & 0.59 & 0.07 \\
\hline Axis 1 & Species Richness & 0.59 & 0.07 \\
\hline Axis 2 & Mean Leaf Area & -0.55 & 0.10 \\
\hline
\end{tabular}

Table 2-16: Pearson correlation (R) and significance for sociodemographic and housing variables and plot cover variables at the council district level.

\begin{tabular}{|l|l|r|c|}
\hline \multicolumn{4}{|c|}{ Council District } \\
\hline \multicolumn{1}{|c|}{$\mathbf{y}$} & \multicolumn{1}{|c|}{$\mathbf{~}$} & $\mathbf{p}$ \\
\hline Axis 1 & \% Plantable Space & -0.05 & n.s. \\
\hline Axis 1 & \% Tree Cover & 0.52 & n.s. \\
\hline Axis 1 & \% Shrub Cover & 0.60 & n.s. \\
\hline Axis 1 & \% Impervious Cover & -0.43 & n.s. \\
\hline Axis 2 & \% Plantable Space & 0.88 & $* *$ \\
\hline Axis 2 & \% Tree Cover & -0.56 & n.s. \\
\hline Axis 2 & \% Shrub Cover & -0.63 & $*$ \\
\hline Axis 2 & \% Impervious Cover & -0.59 & n.s. \\
\hline Axis 3 & \% Plantable Space & 0.06 & n.s. \\
\hline Axis 3 & \% Tree Cover & 0.05 & n.s. \\
\hline Axis 3 & \% Shrub Cover & 0.26 & n.s. \\
\hline Axis 3 & \% Impervious Cover & -0.21 & n.s. \\
\hline
\end{tabular}

$* * \mathrm{p}<0.01$

$* \mathrm{p}<0.05$

n.s. $=$ non-significant 


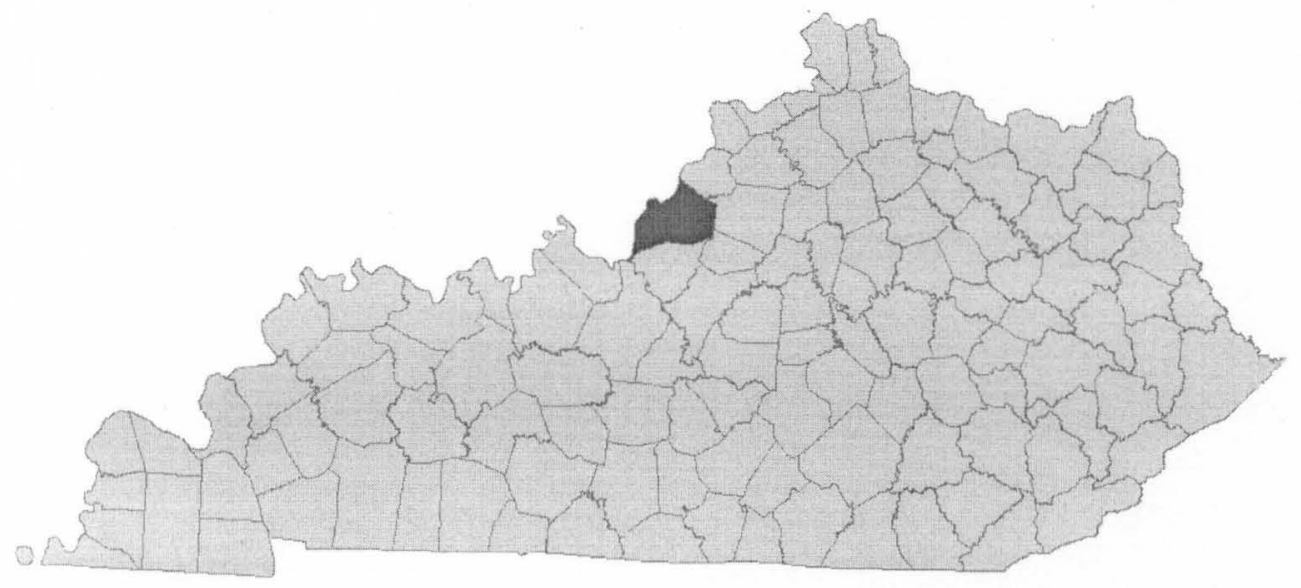

Figure 2-1: Map of Kentucky with Jefferson County highlighted. Source: LOJIC 


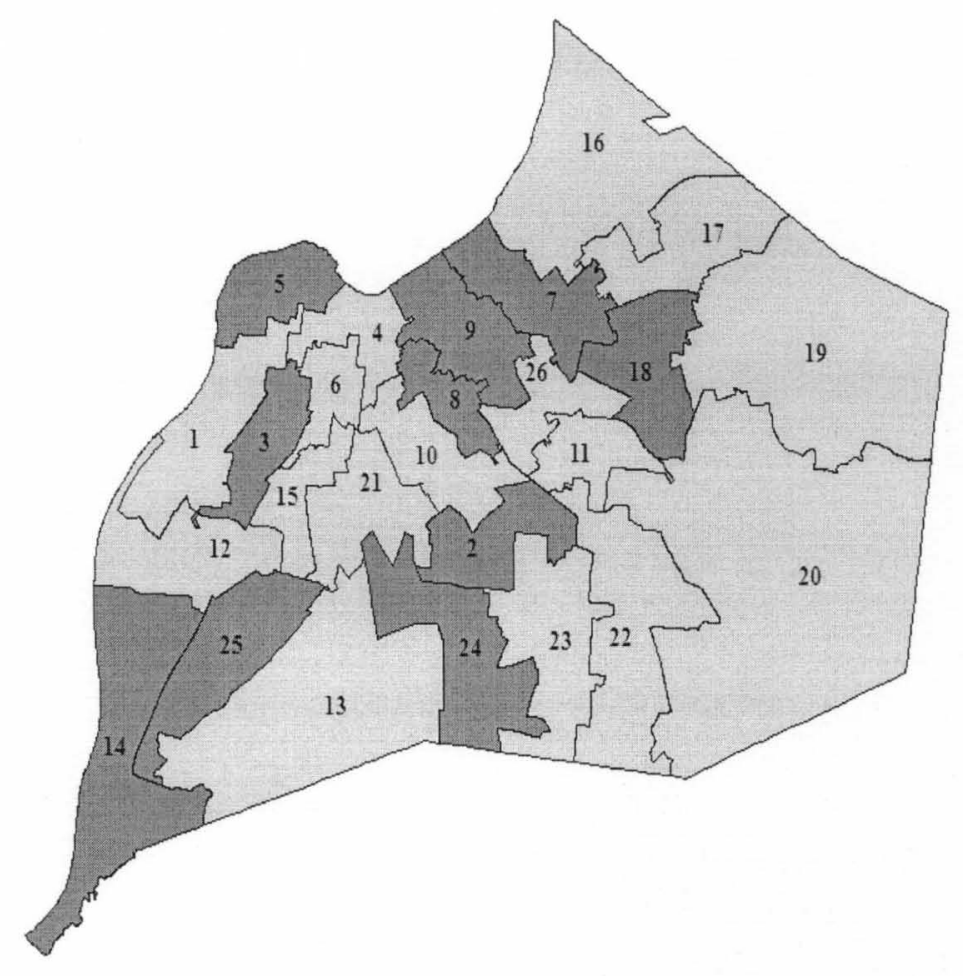

Figure 2-2: Council district map of Louisville-Jefferson County Metro, Kentucky. Council districts used in the study (highlighted): 2, 3, 5, 7, 8, 9, 14, 18, 24, and 25. Source: LOJIC 


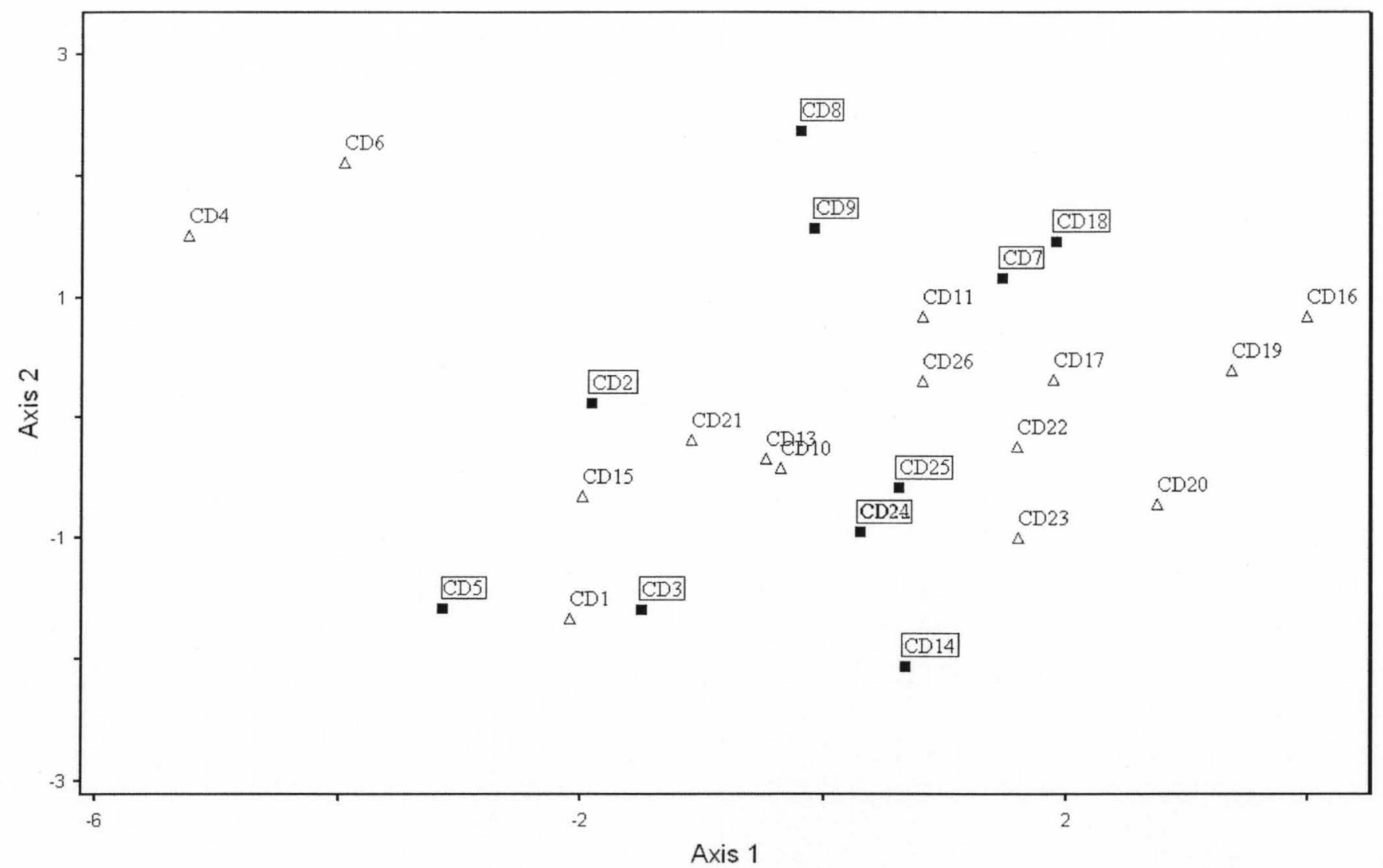

Figure 2-3: Principal Components Analysis (PCA) showing distribution of 10 council districts (square symbols; outlined) used in the UFORE study. Axis 1 variables: Median Income $(0.4442)$ and \% Owner Residents $(0.4183)-$ explained $66 \%$ of the variance. Axis 2 variable: \% Single Homes $(-0.7008)$ - explained $20 \%$ of the variance. (Note: council district 12 was in the exact spot as council district 24 , so it is missing from this graph) 
(a)

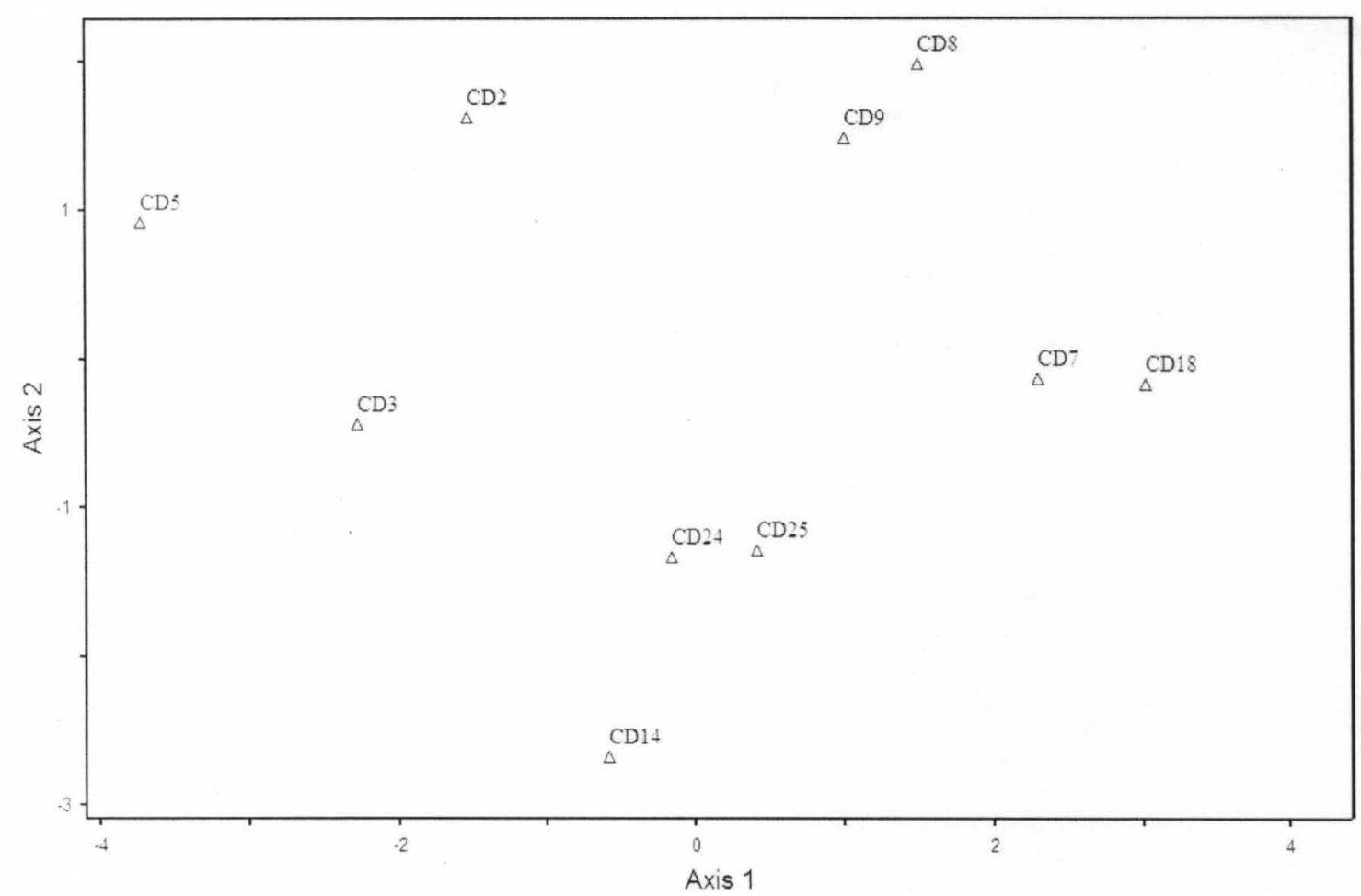

(b)

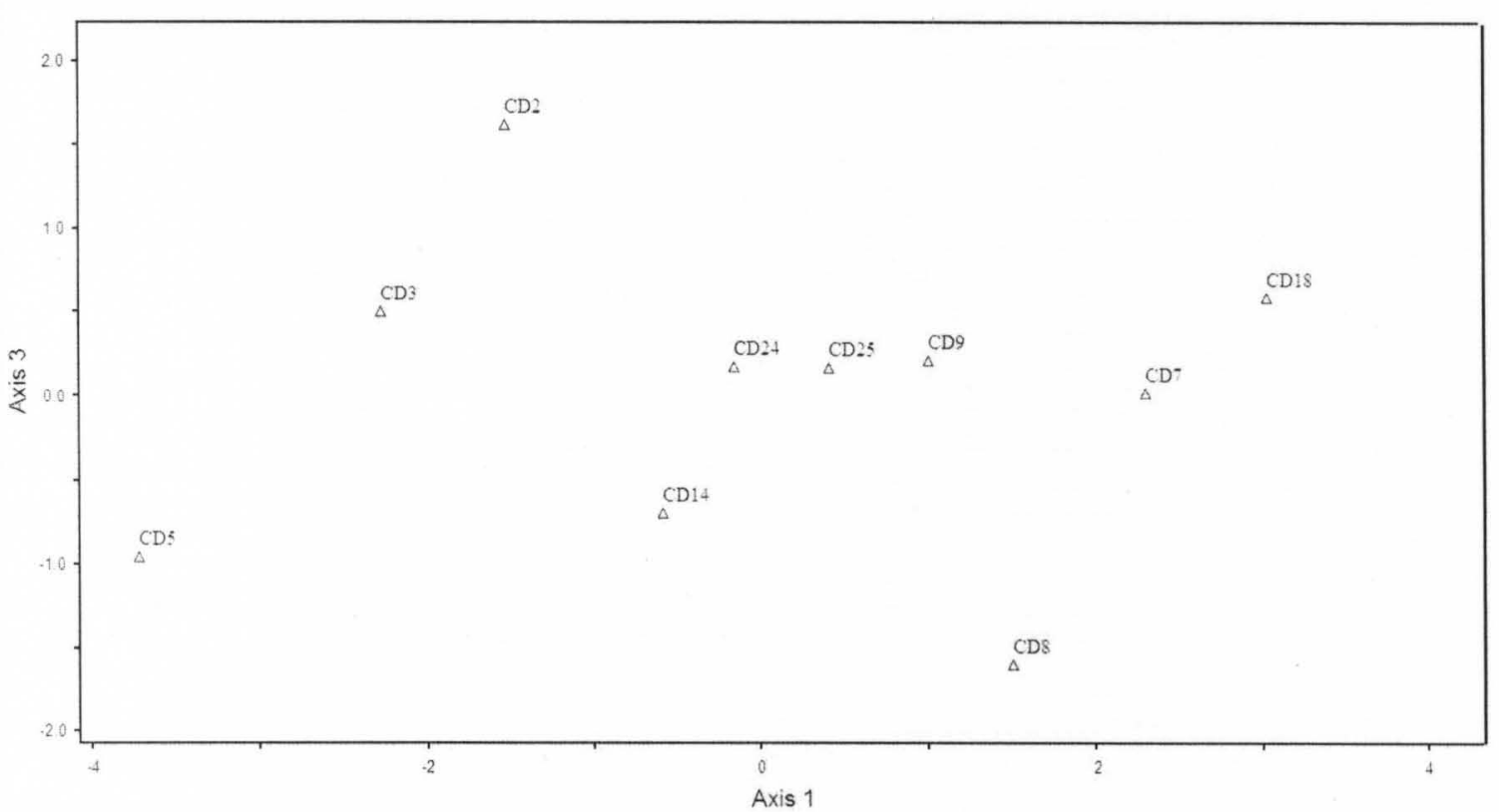

Figure 2-4: Principal Components Analysis (PCA) showing distribution of 10 council districts along the range of socio-demographic and housing variables: (a) PCA axis 1 vs. PCA axis 2; (b) PCA axis 1 vs. PCA axis 3. PCA axis $1=\%$ no high school diploma, median income, and median house value - explained $56.6 \%$ of the variance; PCA axis $2=$ $\%$ single homes and $\%$ owner residents - explained $29.2 \%$ of the variance; PCA axis $3=$ median age of home in 2008 - explained $10.4 \%$ of the variance. 
(a)

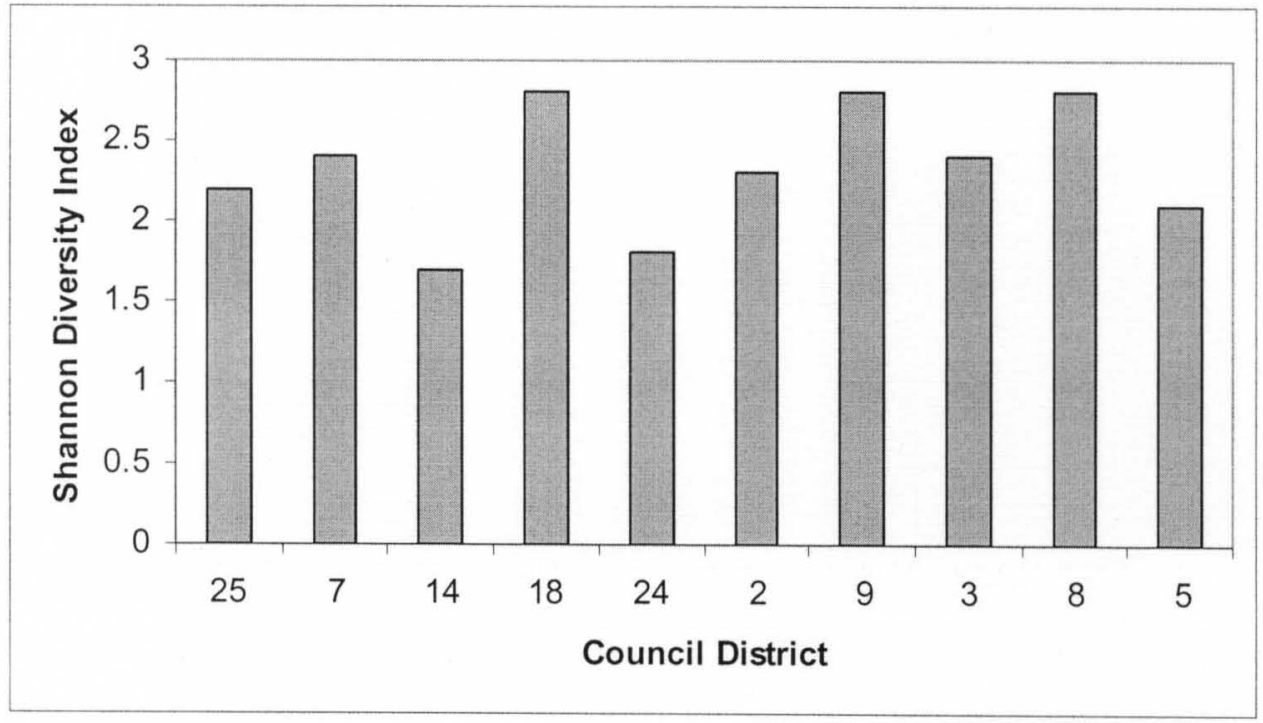

(b)

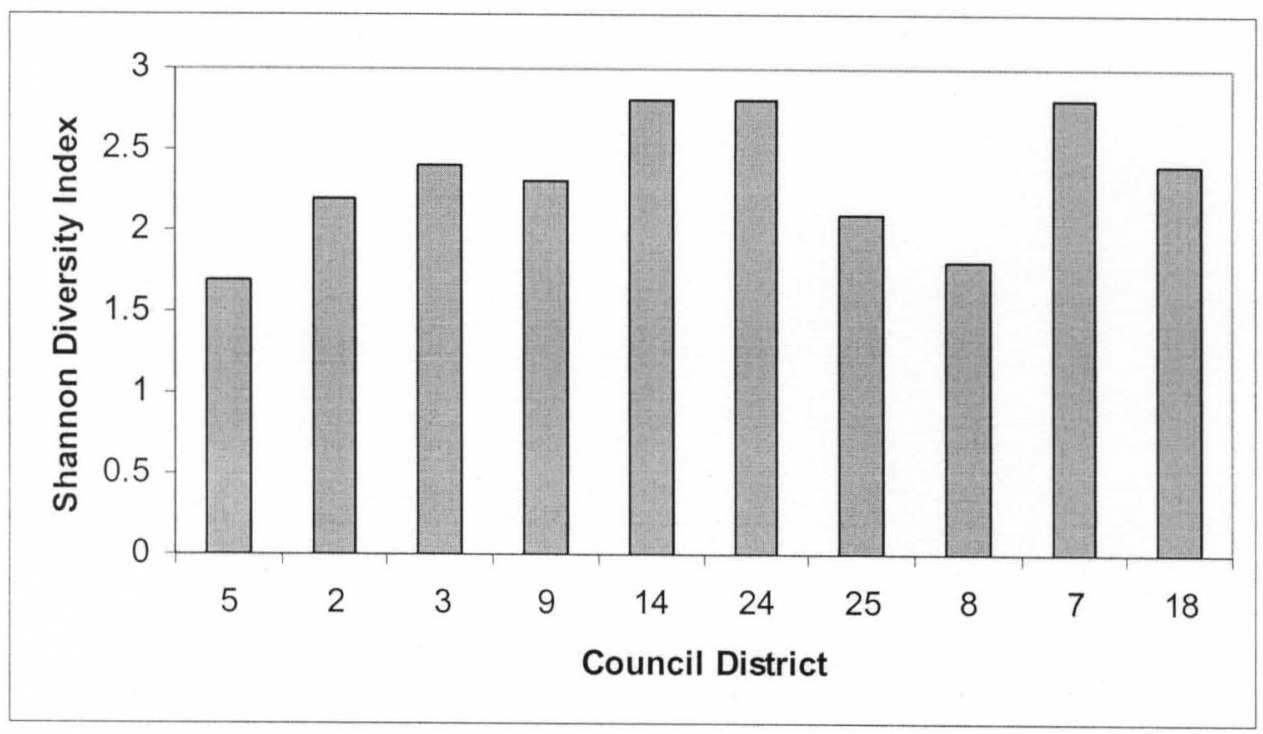

Figure 2-5: Shannon Diversity Index for trees in residential areas of 10 council districts.(a) Council districts arranged in ascending order (left to right) by population density on a per residential land area basis (people ha ${ }^{-1}$ residential land). Population density: range: 14.2 to 40.8 people ha ${ }^{-1}$; mean: 22.6 ; $\mathrm{SE} \pm 2.7$. (b) Council Districts are arranged in ascending order by the median income for the council district. Median income: range: $\$ 24,500-\$ 58,600$; mean: $\$ 39,980$; $\mathrm{SE} \pm \$ 3,300$. Shannon Diversity Index: range 1.7-2.8; mean 2.33; $\mathrm{SE} \pm 1.33$. 
(a)

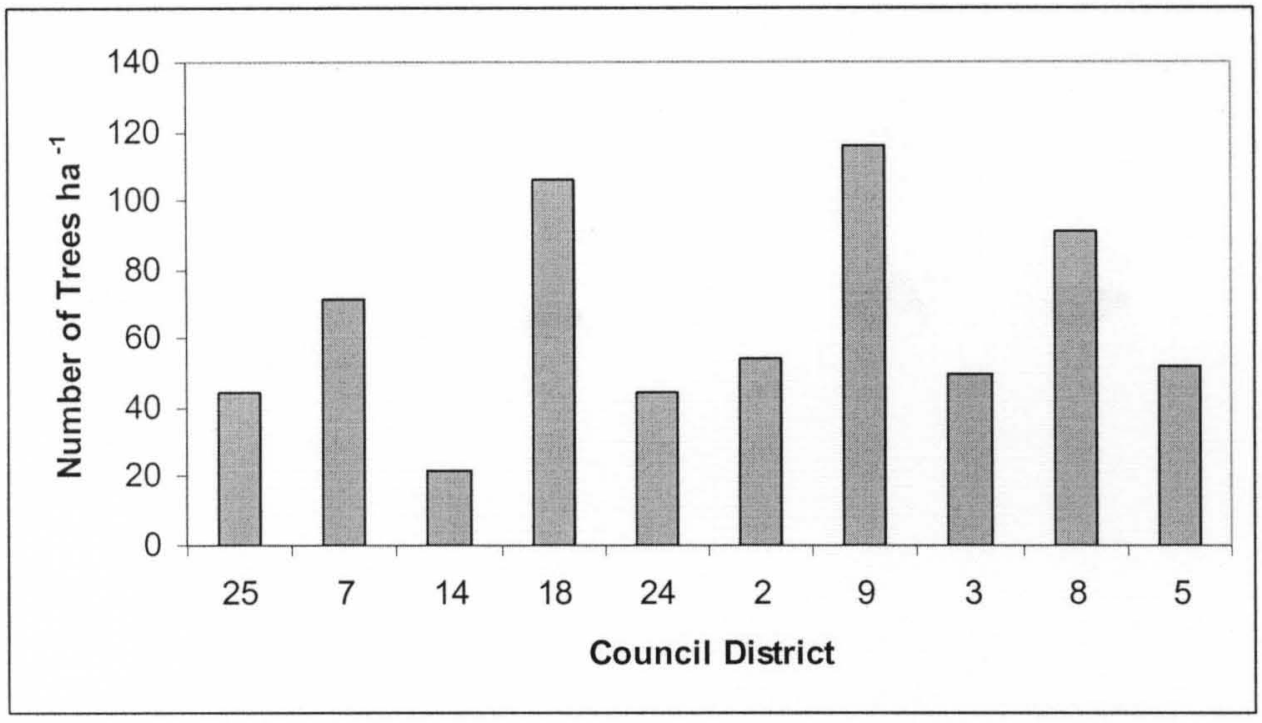

(b)

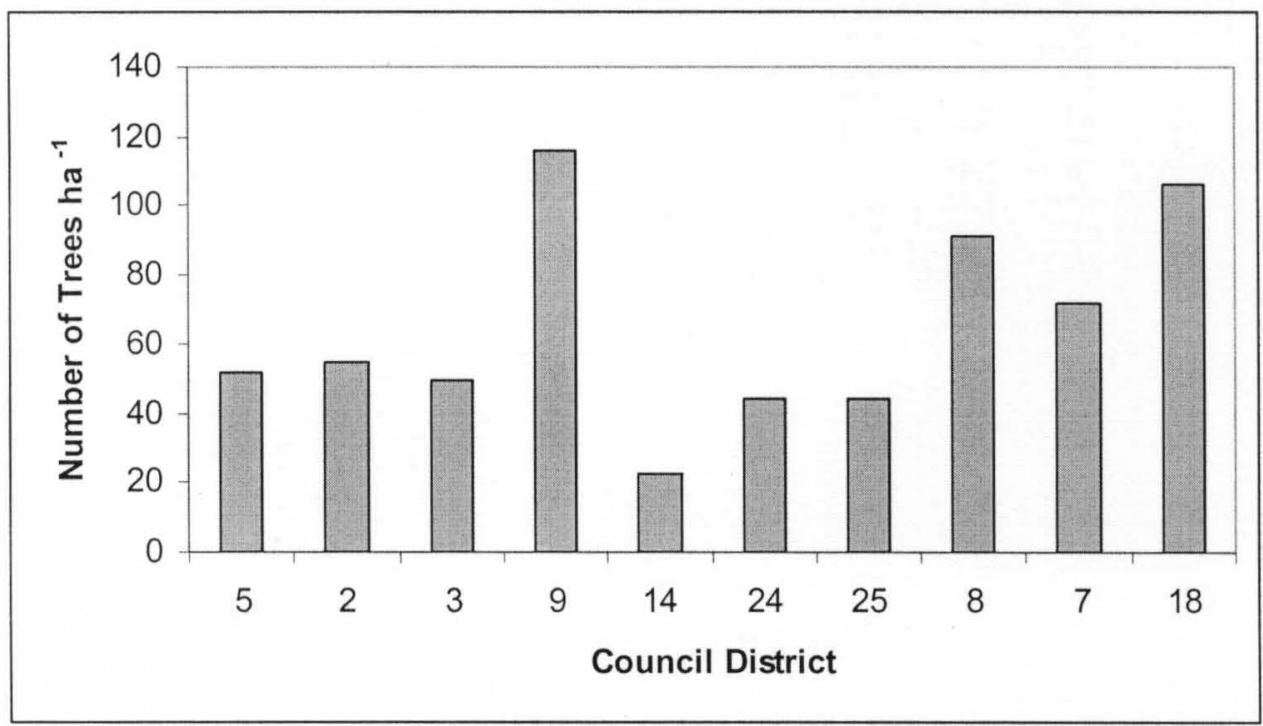

Figure 2-6: UFORE-estimated number of trees $\mathrm{ha}^{-1}$ of residential land in 10 council districts. Estimated number of trees: range: 22.2 to 116.1 trees $\mathrm{ha}^{-1}$; mean: 65.2 trees ha ${ }^{-1} ; \mathrm{SE} \pm 9.6$ trees ha $^{-1}$. (a) Council districts are arranged in ascending order (left to right) by population density on a per residential land area basis (people ha ${ }^{-1}$ residential land) (range: 14.2 to 40.8 people ha ${ }^{-1}$; mean: 22.6; SE \pm 2.7). (b) Council Districts are arranged in ascending order (left to right) by the median income for the council district. Median income: range: $\$ 24,500-\$ 58,600$; mean: $\$ 39,980 ; \mathrm{SE} \pm \$ 3,300$. 


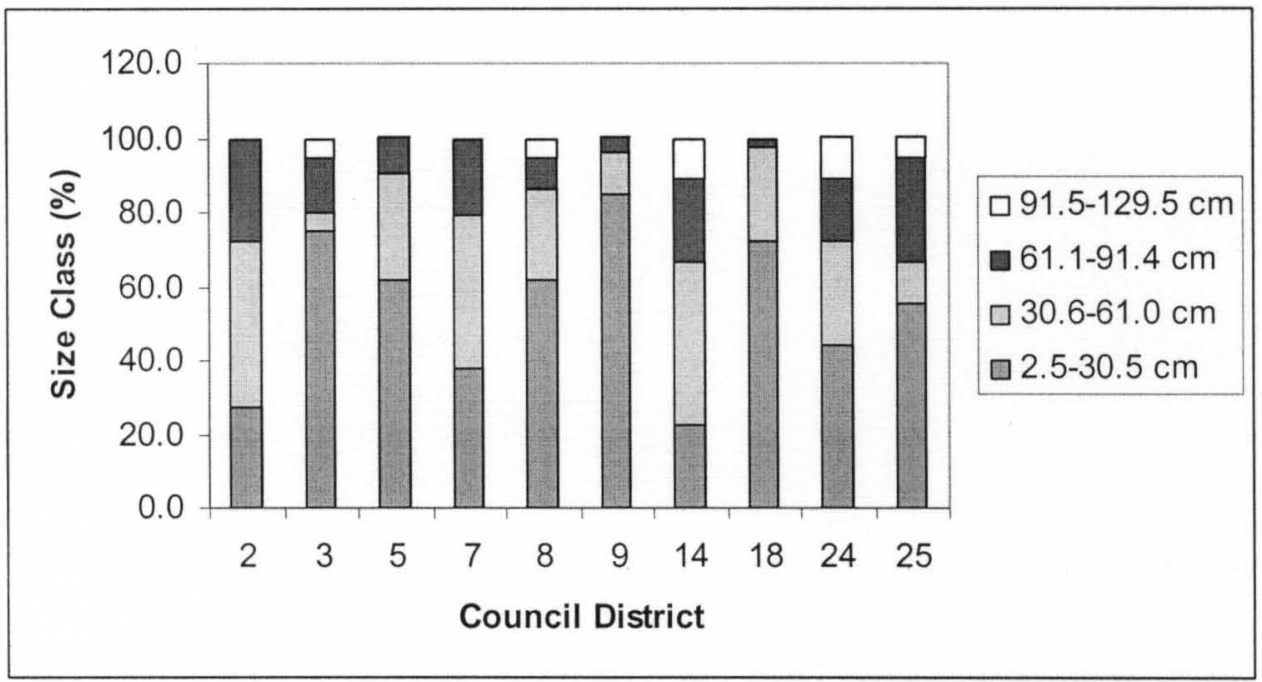

Figure 2-7: DBH $(\mathrm{cm})$ size class by quartiles for trees in residential areas of 10 council districts. 
(a)

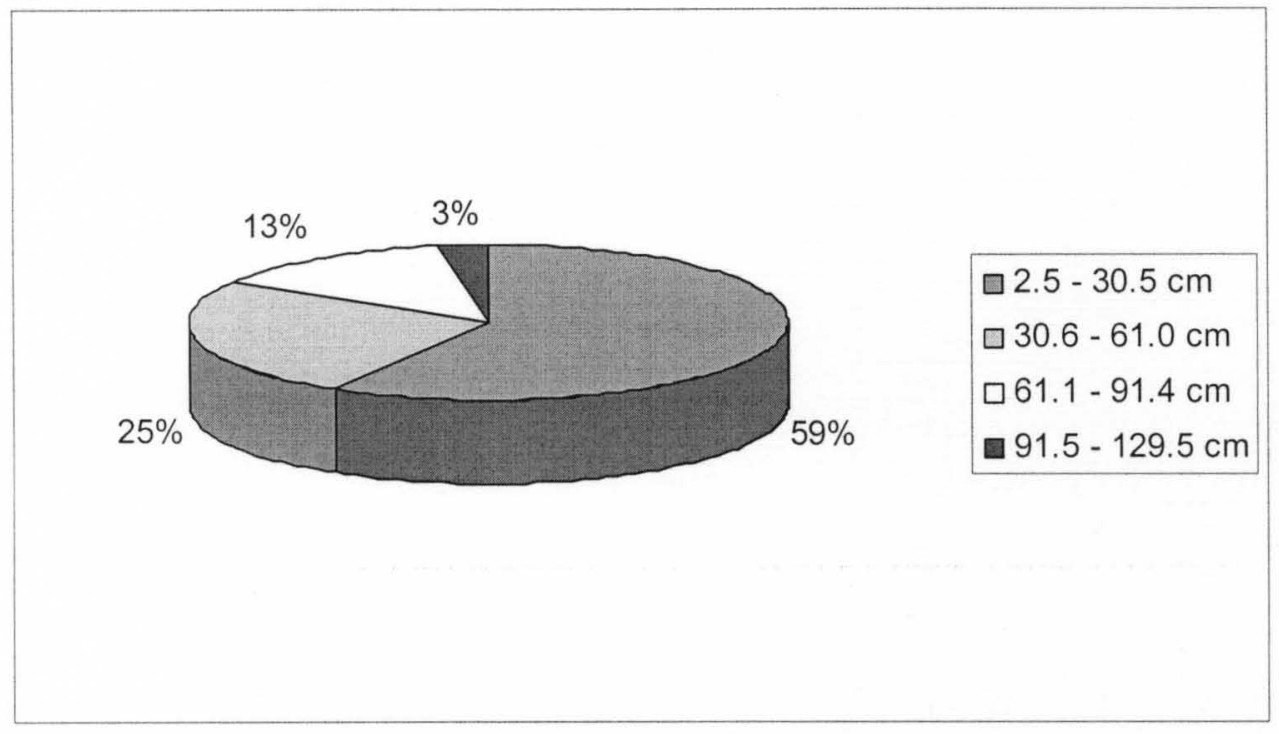

(b)

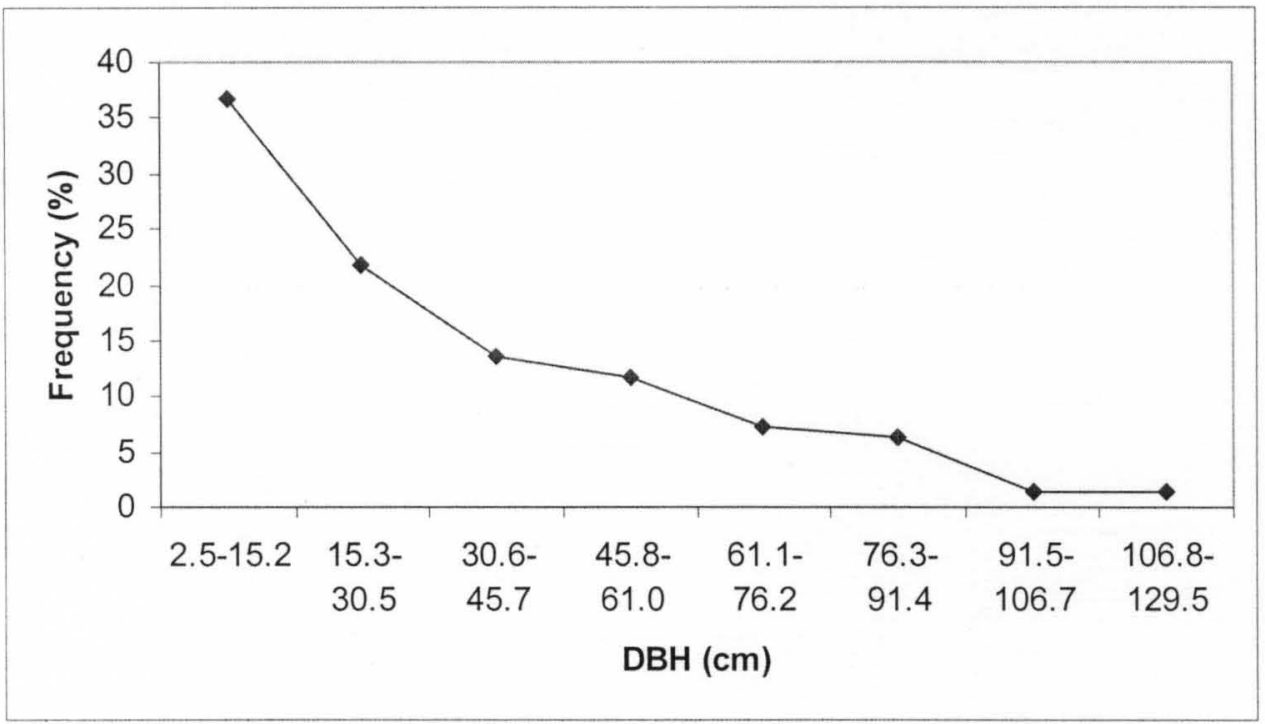

Figure 2-8: (a) DBH (cm) size class range and (b) $\mathrm{DBH}(\mathrm{cm})$ percent frequency in total residential land areas of 10 council districts. Percent frequency refers to what percentage a given size class constitutes of the total tree population. 
(a)

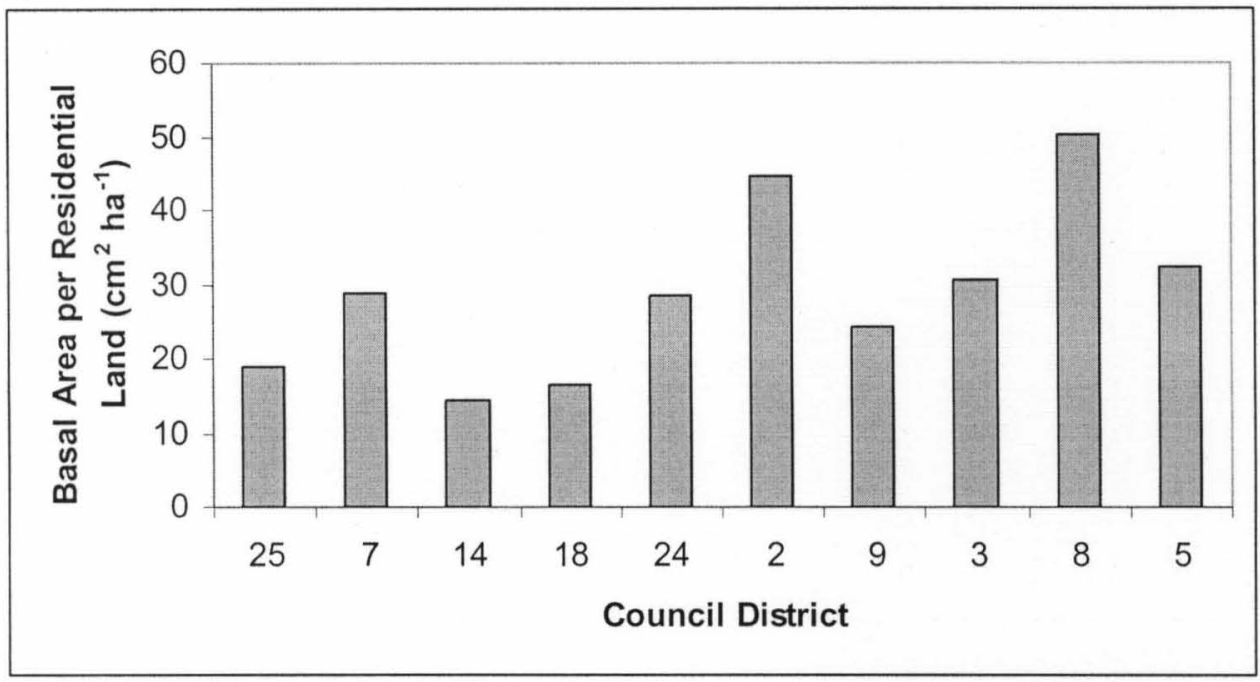

(b)

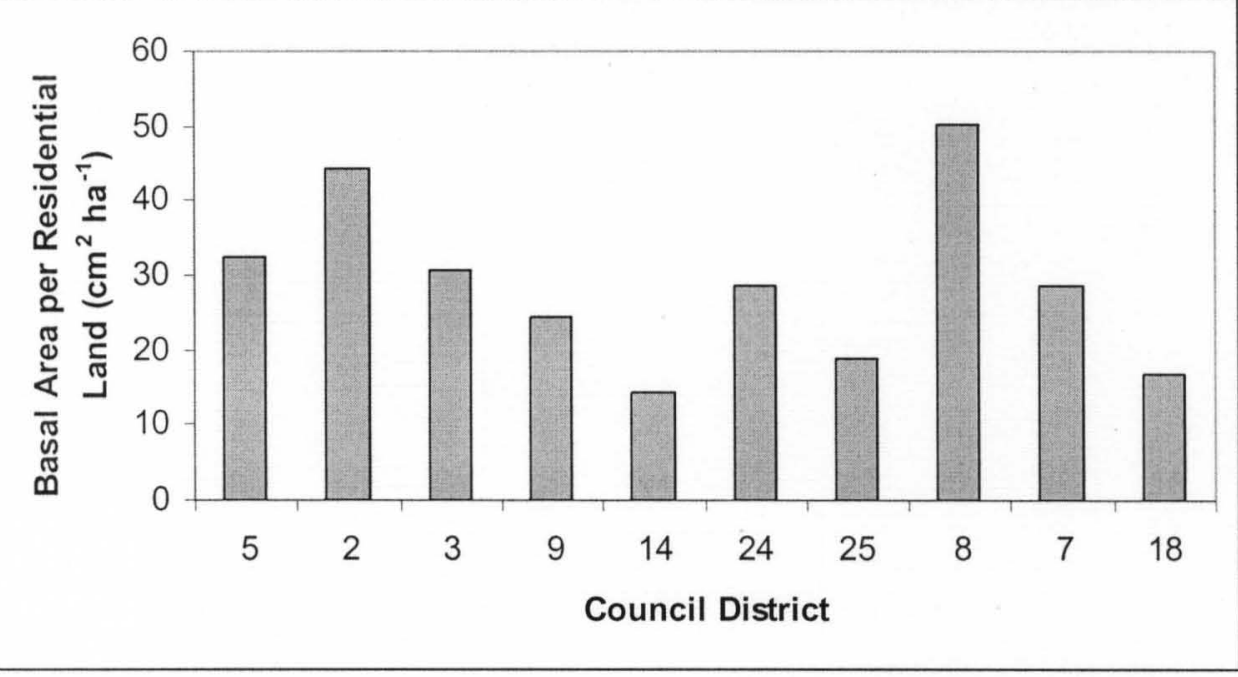

Figure 2-9: Total tree basal area per residential land area (ha) of each of 10 council districts. Tree basal area: range: $14.2-50.3 \mathrm{~cm}^{2} \mathrm{ha}^{-1}$; mean: $28.9 \mathrm{~cm}^{2} \mathrm{ha}^{-1} ; \mathrm{SE} \pm 3.7$ $\mathrm{cm}^{2} \mathrm{ha}^{-1}$. (a) Council districts arranged in ascending order by residential land area population density (people ha ${ }^{-1}$ ). Population density: range: 14.2 to 40.8 people ha ${ }^{-1}$; mean: 22.6 ; $\mathrm{SE} \pm 2.7$. (b) Council districts arranged in ascending order by council district median income: range: $\$ 24,500-\$ 58,600$; mean: $\$ 39,980 ; \mathrm{SE} \pm \$ 3,300$. 
(a)

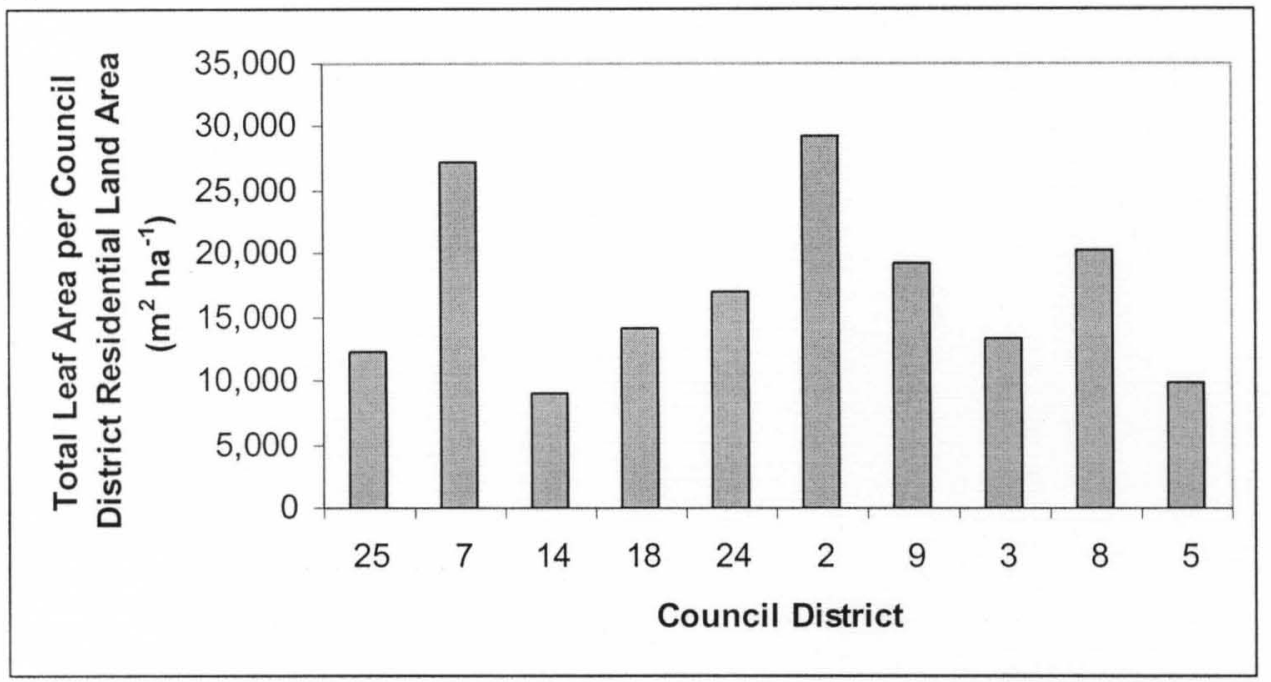

(b)

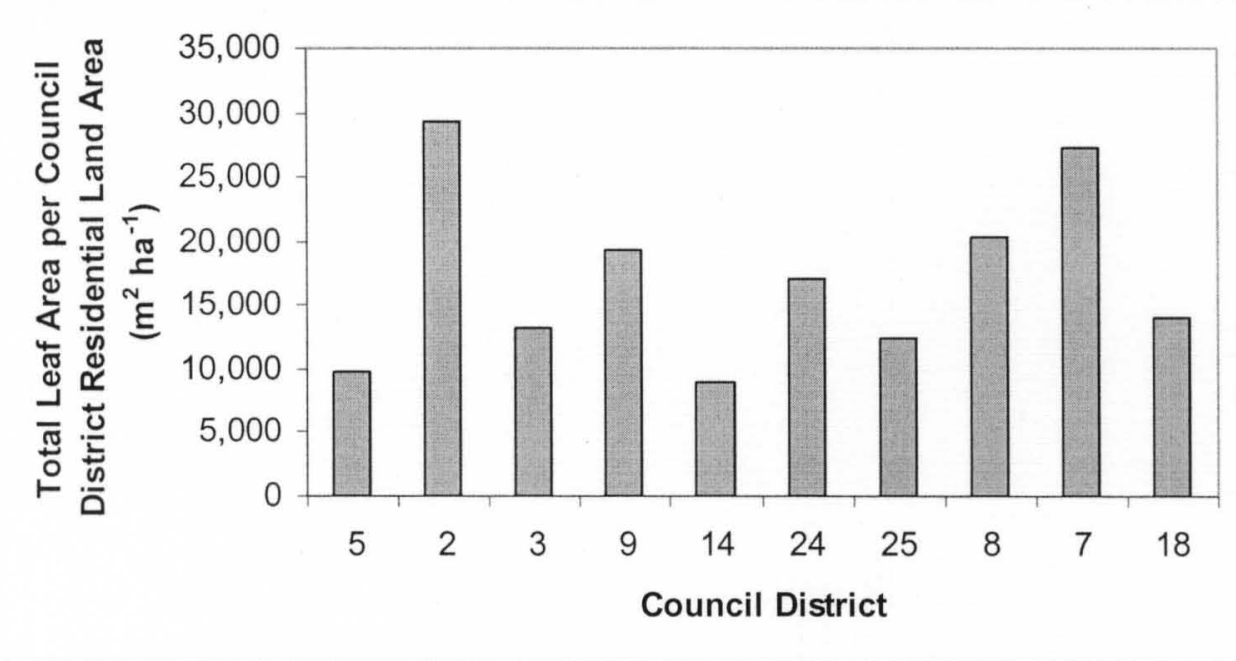

Figure 2-10: UFORE-estimated total leaf area per council district residential land area $\left(\mathrm{m}^{2} \mathrm{ha}^{-1}\right)$. Leaf area: range: 8,933-29,272 $\mathrm{m}^{2} \mathrm{ha}^{-1}$; mean: $17,148 \mathrm{~m}^{2} \mathrm{ha}^{-1}$; $\mathrm{SE} \pm 2,194 \mathrm{~m}^{2} \mathrm{ha}^{-1}$. (a) Council districts arranged in ascending order by residential land area population density (people $\mathrm{ha}^{-1}$ ). Population density: range: 14.2 to 40.8 people $\mathrm{ha}^{-1}$; mean: $22.6 ; \mathrm{SE} \pm 2.7$. (b) Council districts arranged in ascending order by council district median income: range: $\$ 24,500-\$ 58,600$; mean: $\$ 39,980$; $\mathrm{SE} \pm \$ 3,300$. 
(a)

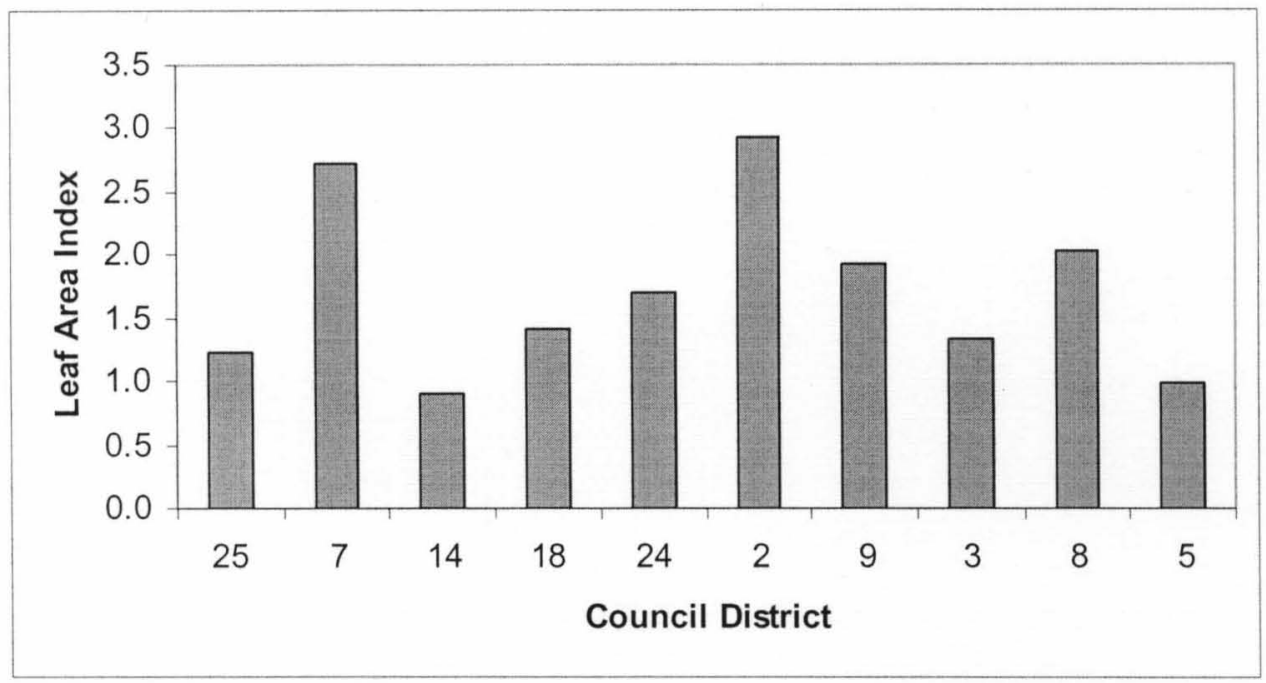

(b)

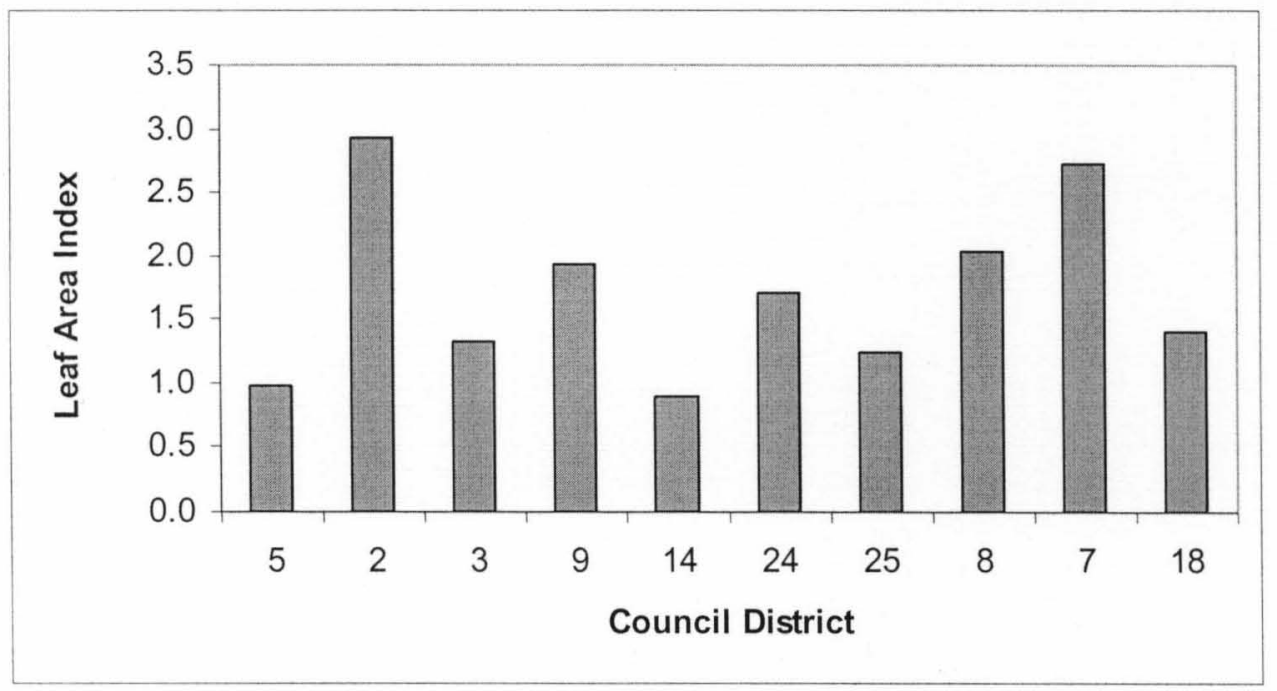

Figure 2-11: Total Leaf Area Index (LAI) of residential land area in 10 council districts. LAI: range: 0.89-2.93; mean: 1.71 ; $\mathrm{SE} \pm 0.22$.

(a) Council districts arranged in ascending order by residential land area population density (people $\mathrm{ha}^{-1}$ ). Population density: range: 14.2 to 40.8 people ha $^{-1}$; mean: 22.6; $\mathrm{SE} \pm 2.7$. (b) Council districts arranged in ascending order by council district median income: range: $\$ 24,500-\$ 58,600$; mean: $\$ 39,980$; $\mathrm{SE} \pm \$ 3,300$. 
(a)

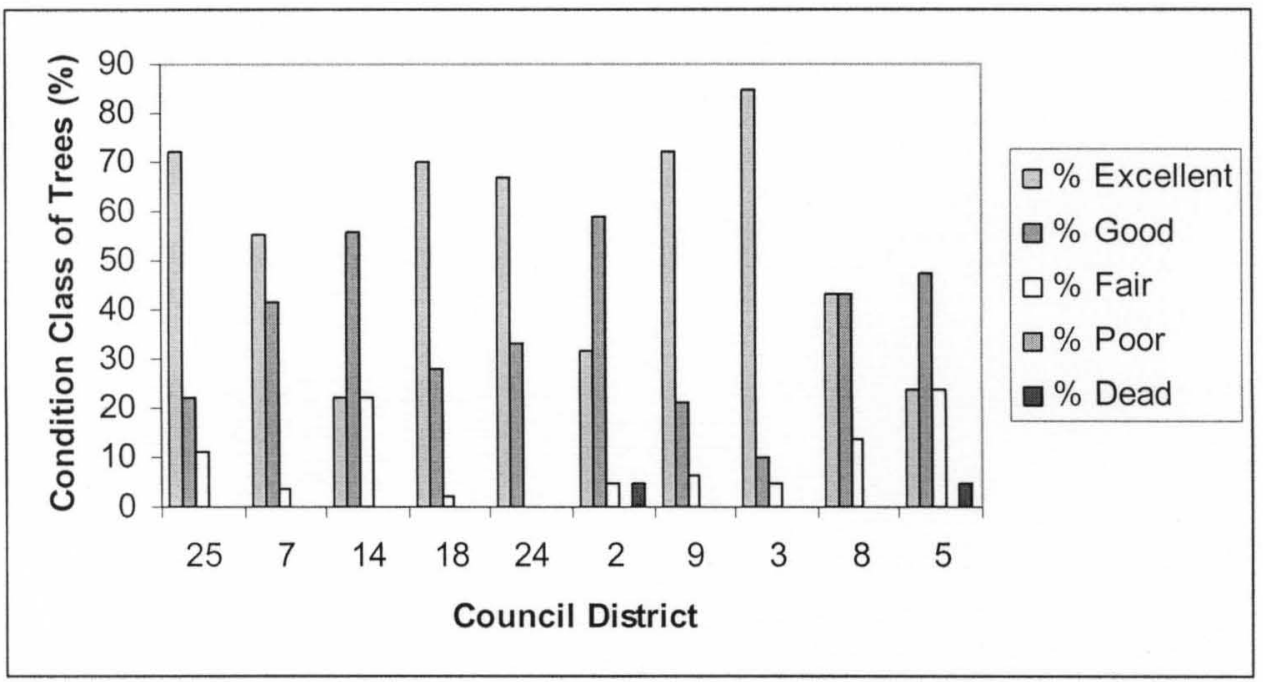

(b)

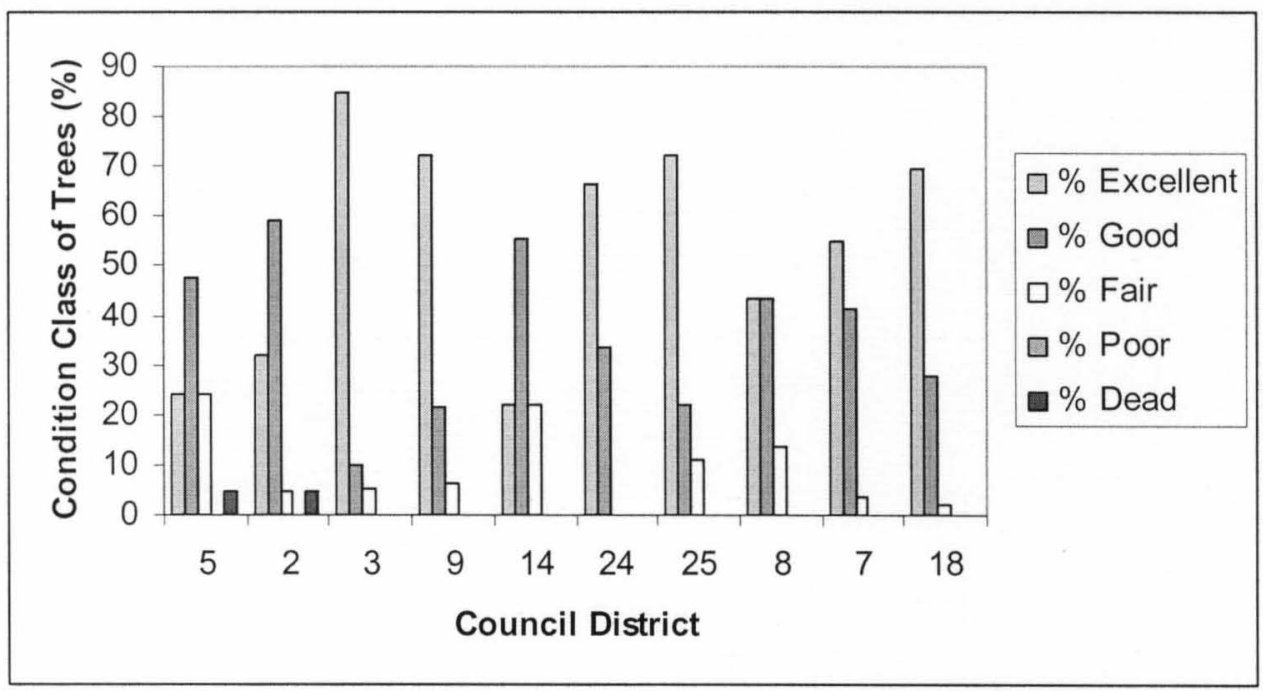

Figure 2-12: Condition class of trees (\%) in residential land areas of 10 council districts. (a) Council districts arranged in ascending order by residential land area population density (people ha ${ }^{-1}$ ). Population density: range: 14.2 to 40.8 people ha ${ }^{-1}$; mean: 22.6; SE \pm 2.7. (b) Council districts arranged in ascending order by council district median income: range: $\$ 24,500-\$ 58,600$; mean: $\$ 39,980$; $\mathrm{SE} \pm \$ 3,300$. Note: There were no trees in any of the council districts in the "poor" condition class. 


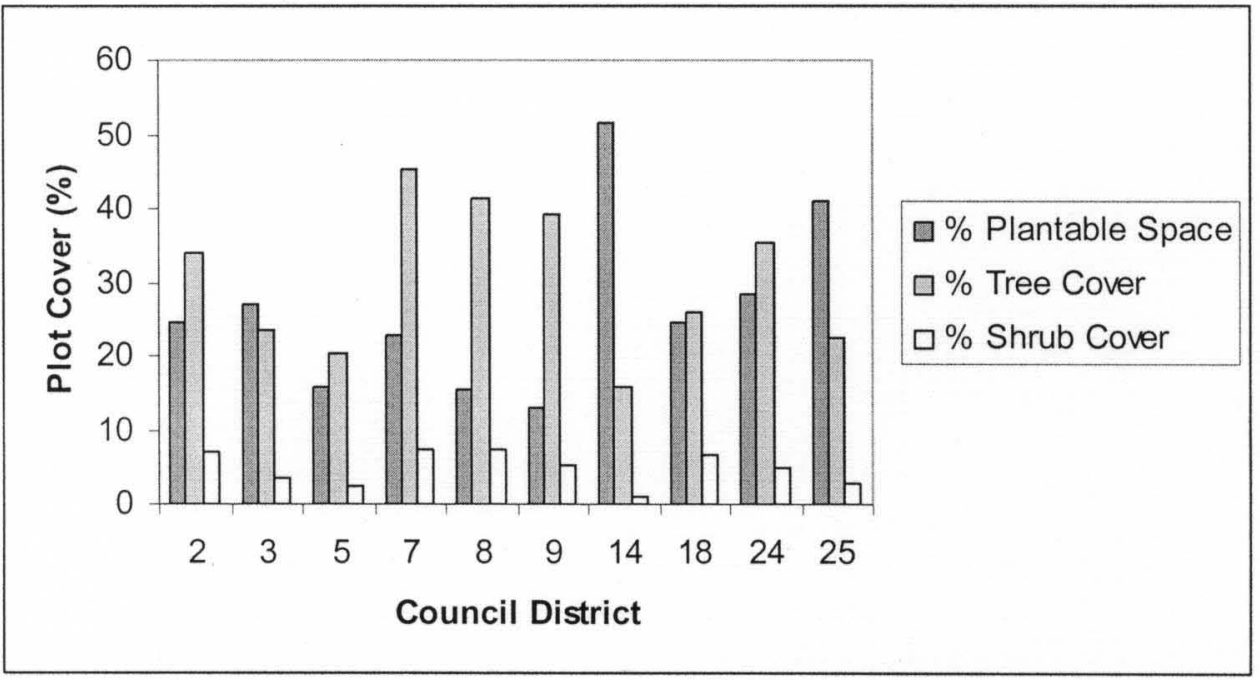

Figure 2-13: Plot coverage percentages by council district. 
(a)

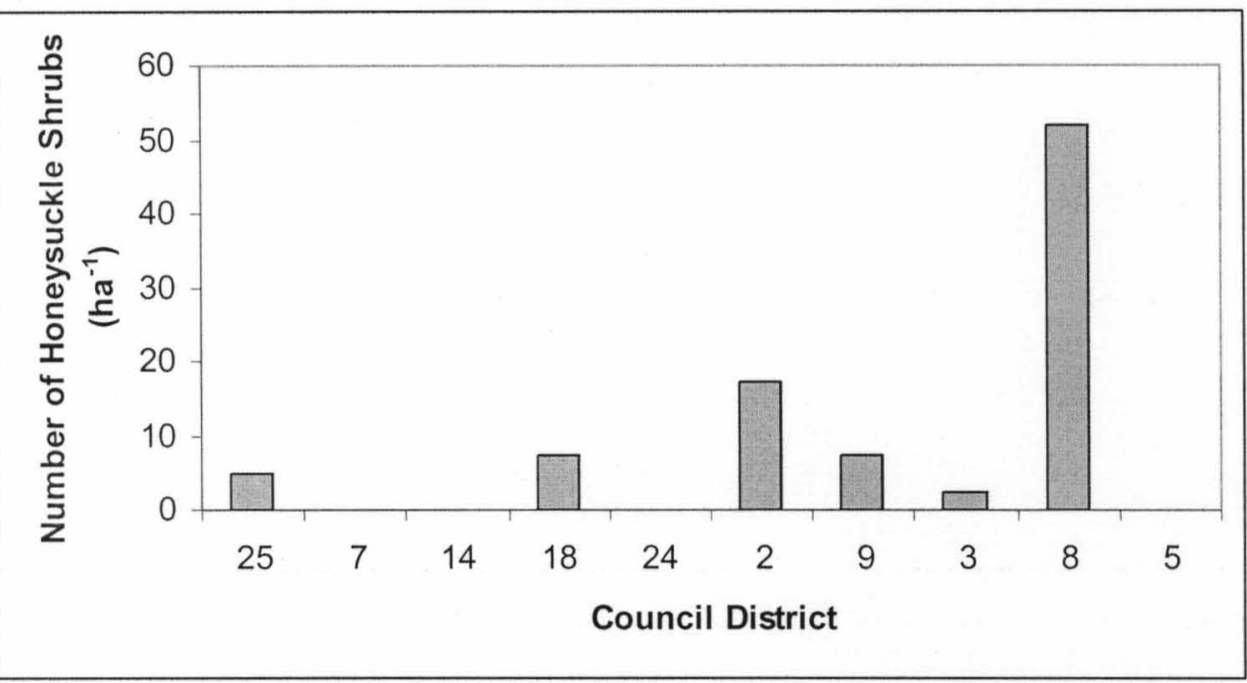

(b)

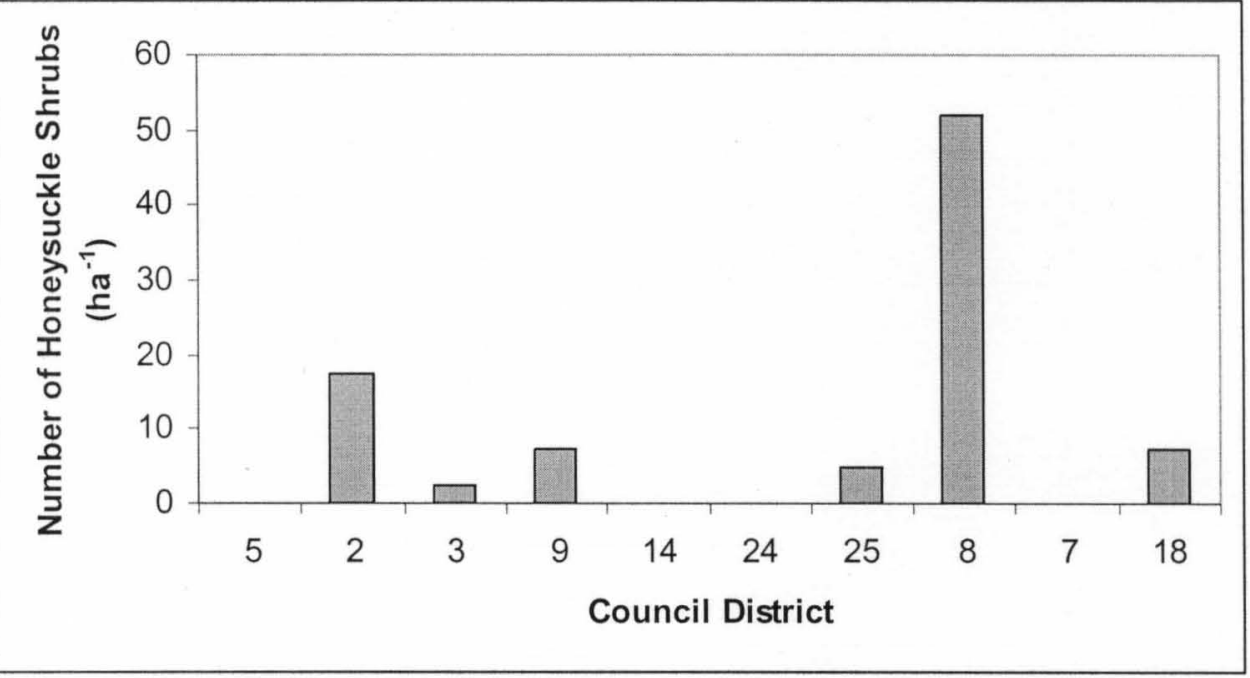

Figure 2-14: Number of honeysuckle (Lonicera maackii) shrubs per hectare of residential land use in each council district. Number of honeysuckle shrubs: range: $0-51.9 \mathrm{ha}^{-1}$; mean $9.1 \mathrm{ha}^{-1} ; \mathrm{SE} \pm 5.1 \mathrm{ha}^{-1}$. (a) Council districts arranged in ascending order by residential land area population density (people ha ${ }^{-1}$ ). Population density: range: 14.2 to 40.8 people ha $^{-1}$; mean: 22.6 ; $\mathrm{SE} \pm 2.7$. (b) Council districts arranged in ascending order by council district median income: range: $\$ 24,500-\$ 58,600$; mean: $\$ 39,980 ; \mathrm{SE} \pm \$ 3,300$. 
(a)

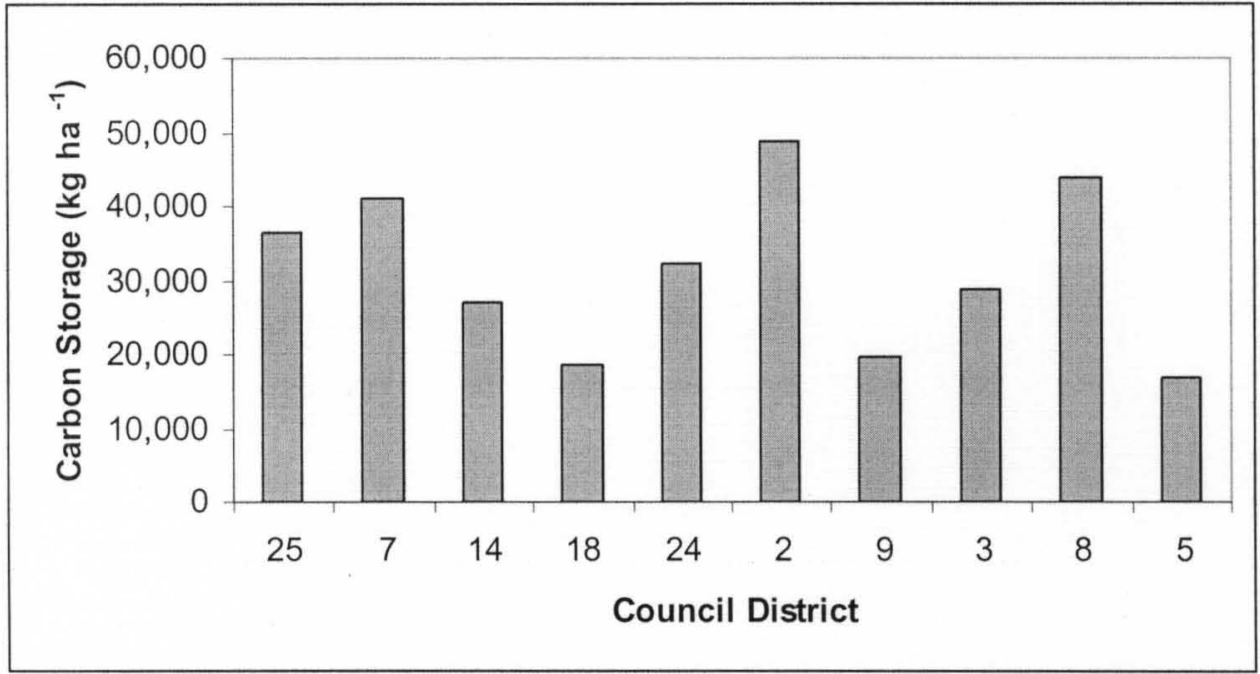

(b)

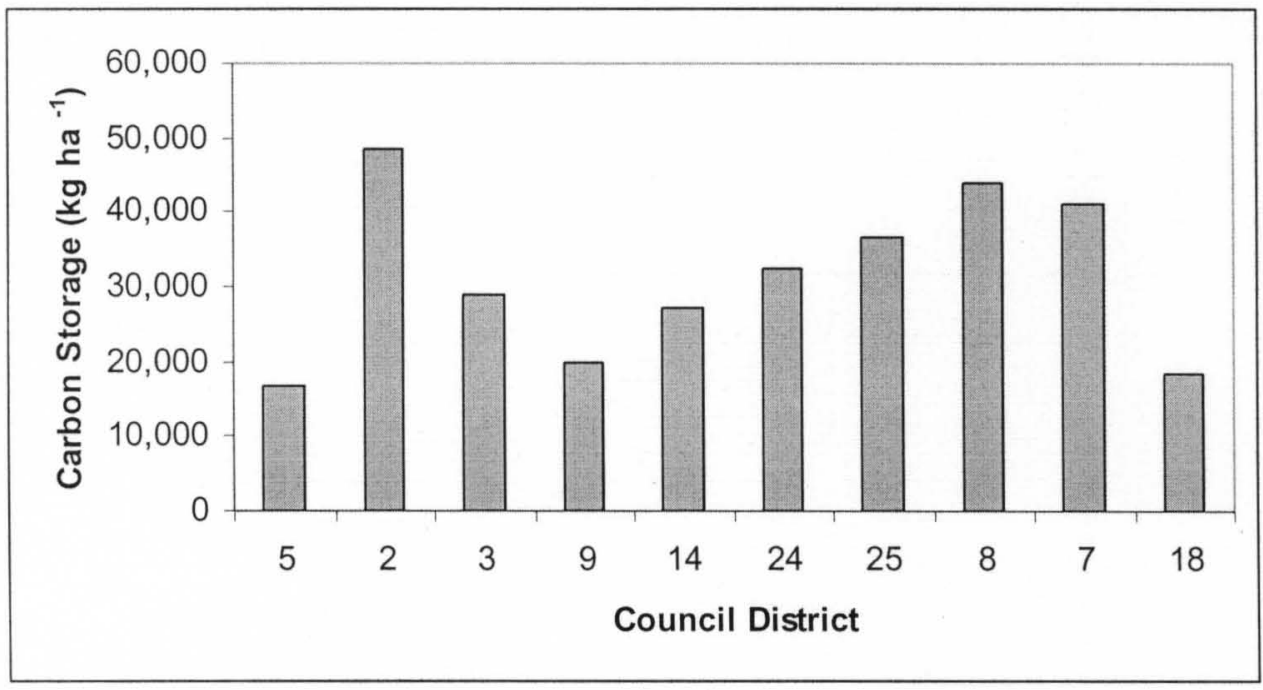

Figure 2-15: Carbon stored by trees per ha of residential land area in 10 council districts. Carbon storage: range: $16,712-48,648 \mathrm{~kg} \mathrm{ha}^{-1}$; mean $31,392 \mathrm{~kg} \mathrm{ha}^{-1}$; $\mathrm{SE} \pm 3,521$. (a) Council districts arranged in ascending order by residential land area population density (people $\mathrm{ha}^{-1}$ ). Population density: range: 14.2 to 40.8 people ha ${ }^{-1}$; mean: 22.6; $\mathrm{SE} \pm 2.7$. (b) Council districts arranged in ascending order by council district median income: range: $\$ 24,500-\$ 58,600$; mean: $\$ 39,980 ; \mathrm{SE} \pm \$ 3,300$. 
(a)

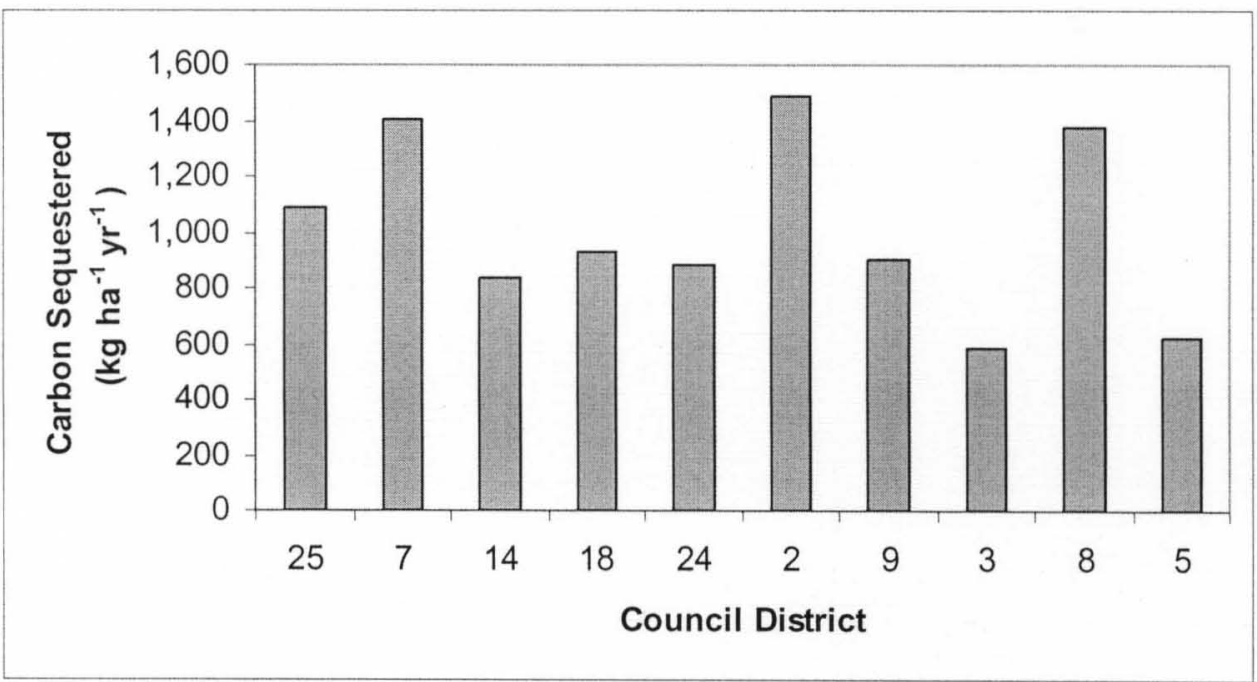

(b)

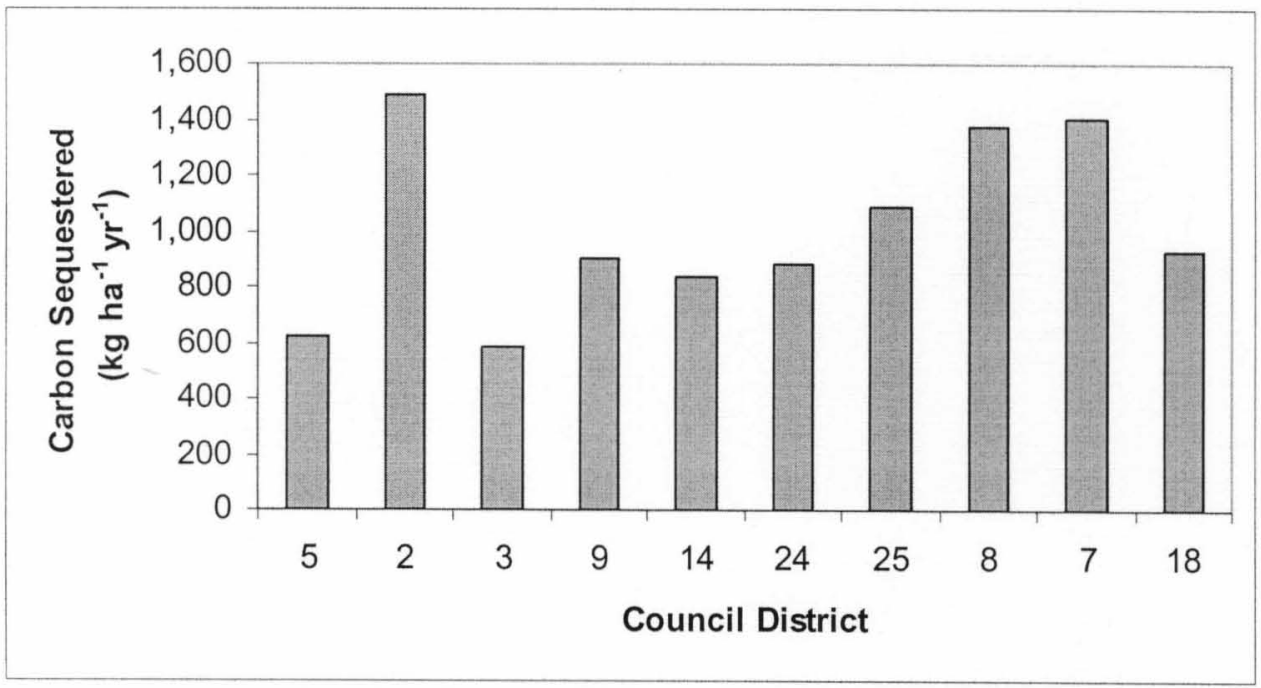

Figure 2-16: Carbon sequestered by trees in the residential land areas of 10 council districts. Carbon sequestration: range: $623-1,485 \mathrm{~kg} \mathrm{ha}^{-1} \mathrm{yr}^{-1}$; mean: 1,102 $\mathrm{kg} \mathrm{ha}^{-1} \mathrm{yr}^{-1} ; \mathrm{SE} \pm 101 \mathrm{~kg} \mathrm{ha}^{-1} \mathrm{yr}^{-1}$. (a) Council districts arranged in ascending order by residential land area population density $\left(\right.$ people $\left.\mathrm{ha}^{-1}\right)$. Population density: range: 14.2 to 40.8 people ha ${ }^{-1}$; mean: 22.6 ; $\mathrm{SE} \pm 2.7$. (b) Council districts arranged in ascending order by council district median income: range: \$24,500-\$58,600; mean: \$39,980; SE $\pm \$ 3,300$. 
(a)

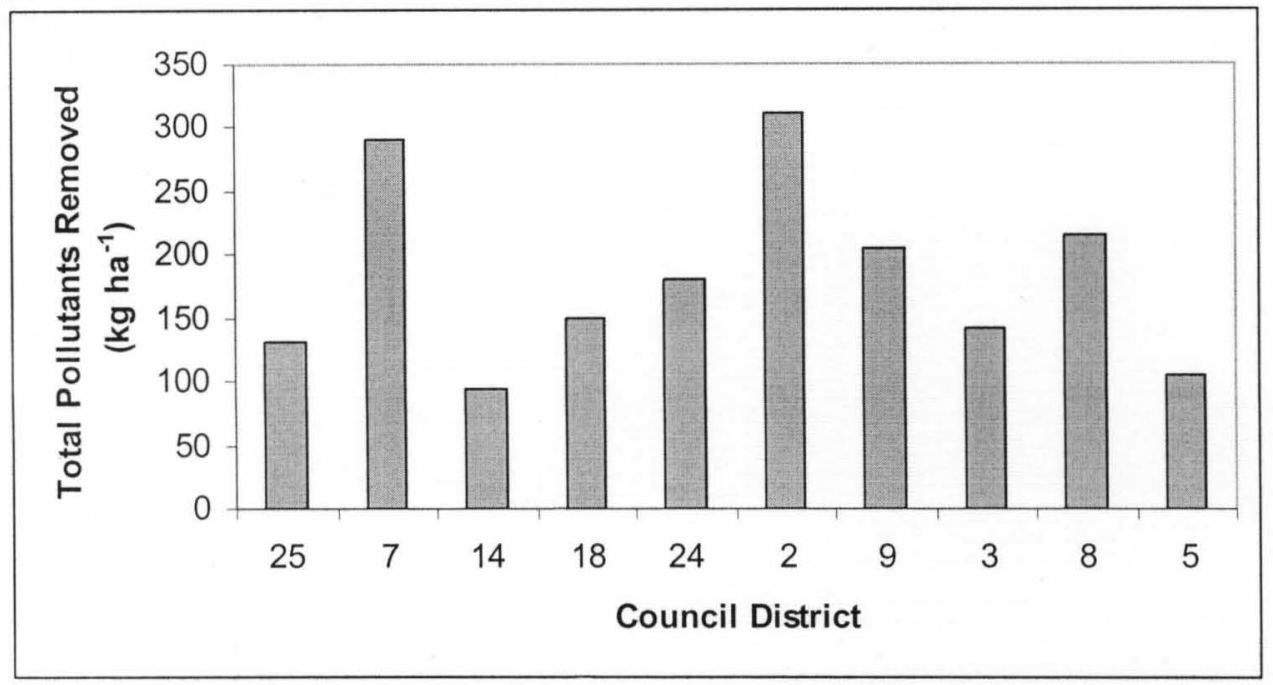

(b)

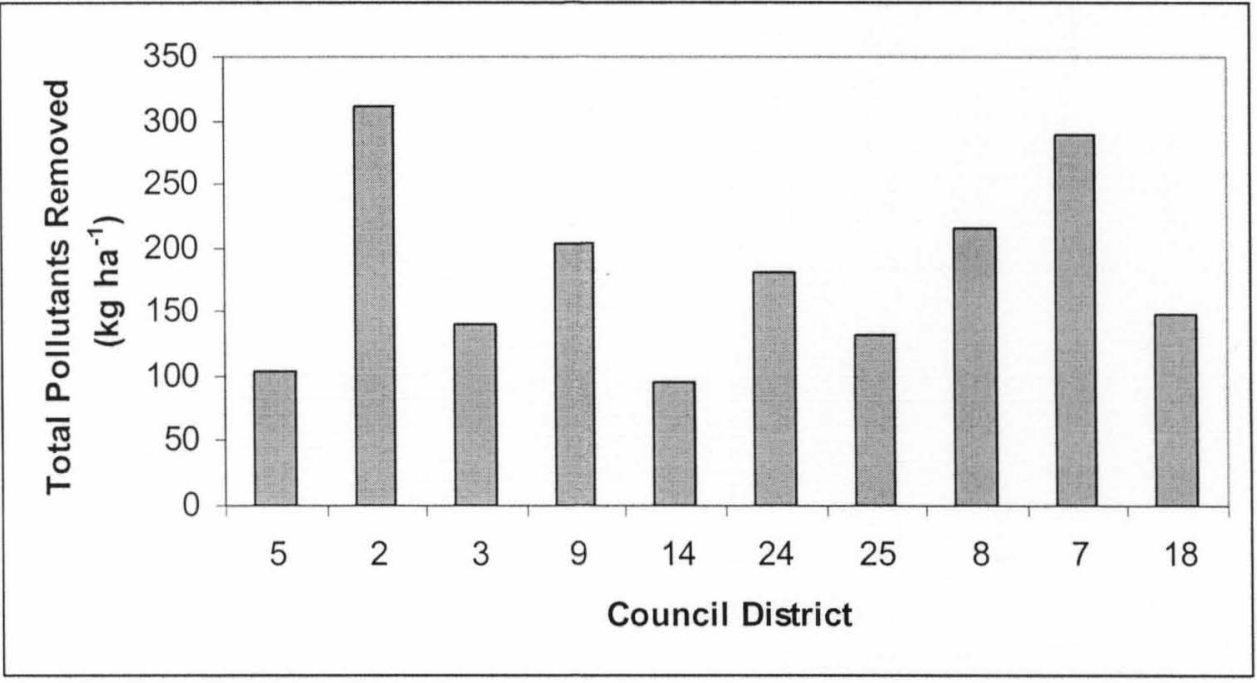

Figure 2-17: Total pollutants removed annually by trees in residential land areas of 10 council districts. Pollutants removed: range: $94.9-311 \mathrm{~kg} \mathrm{ha}^{-1}$; mean: $182.2 \mathrm{~kg} \mathrm{ha}^{-1} ; \mathrm{SE} \pm 23.3 \mathrm{~kg} \mathrm{ha}^{-1}$. (a) Council districts arranged in ascending order by residential land area population density (people ha ${ }^{-1}$ ). Population density: range: 14.2 to 40.8 people ha $^{-1}$; mean: 22.6 ; $\mathrm{SE} \pm 2.7$. (b) Council districts arranged in ascending order by council district median income: range: $\$ 24,500-\$ 58,600$; mean: $\$ 39,980 ; \mathrm{SE} \pm \$ 3,300$. 


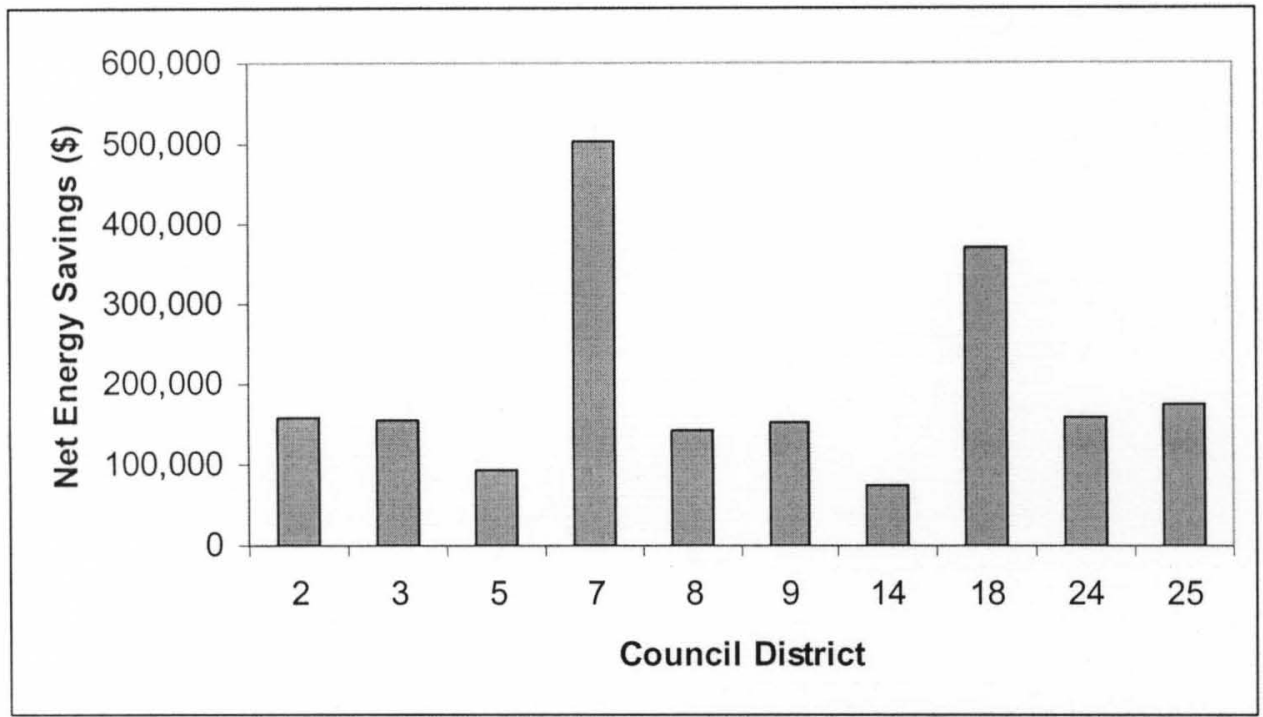

Figure 2-18: Net energy savings in dollars for residential areas of 10 council districts. The 2008 Louisville Gas and Electric (LG\&E) rate of $\$ 0.064 \mathrm{kWh}^{-1}$ was used to determine money saved due to decreased energy use. 
(a)

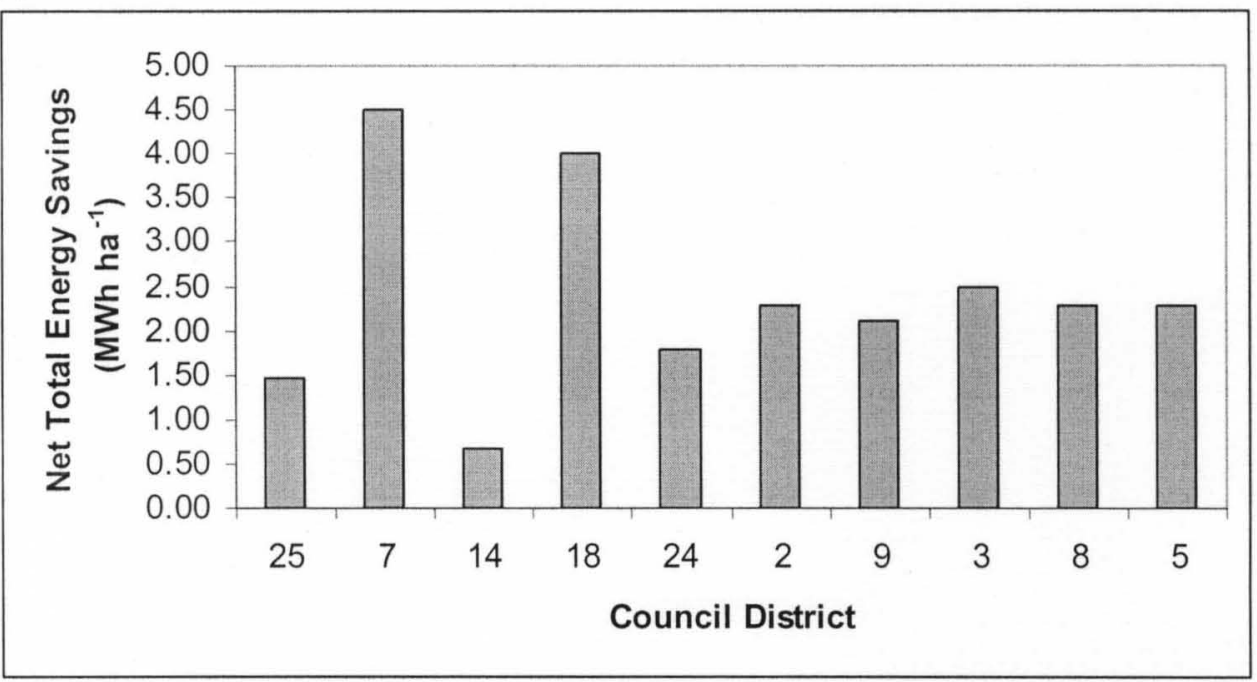

(b)

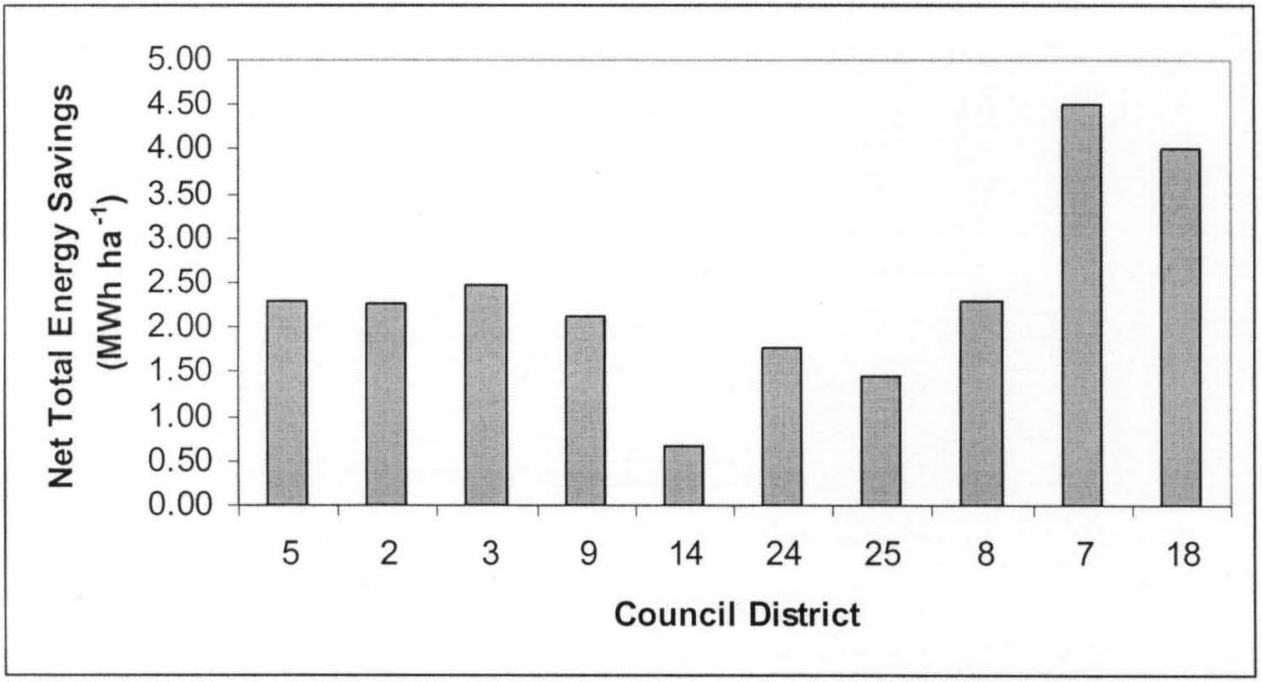

Figure 2-19: Net total energy savings due to tree shading, windbreak, and climate effects in residential land areas of 10 council districts. Net total energy savings: range: 0.67-4.51 $\mathrm{MWh} \mathrm{ha}^{-1}$; mean: 2.39 $\mathrm{MWh} \mathrm{ha}^{-1}$; SE $\pm 0.36 \mathrm{MWh} \mathrm{ha}^{-1}$.

(a) Council districts arranged in ascending order by residential land area population density (people ha ${ }^{-1}$ ). Population density: range: 14.2 to 40.8 people $\mathrm{ha}^{-1}$; mean: 22.6; $\mathrm{SE} \pm 2.7$. (b) Council districts arranged in ascending order by council district median income: range: $\$ 24,500-\$ 58,600$; mean: $\$ 39,980$; $\mathrm{SE} \pm \$ 3,300$. 
(a)

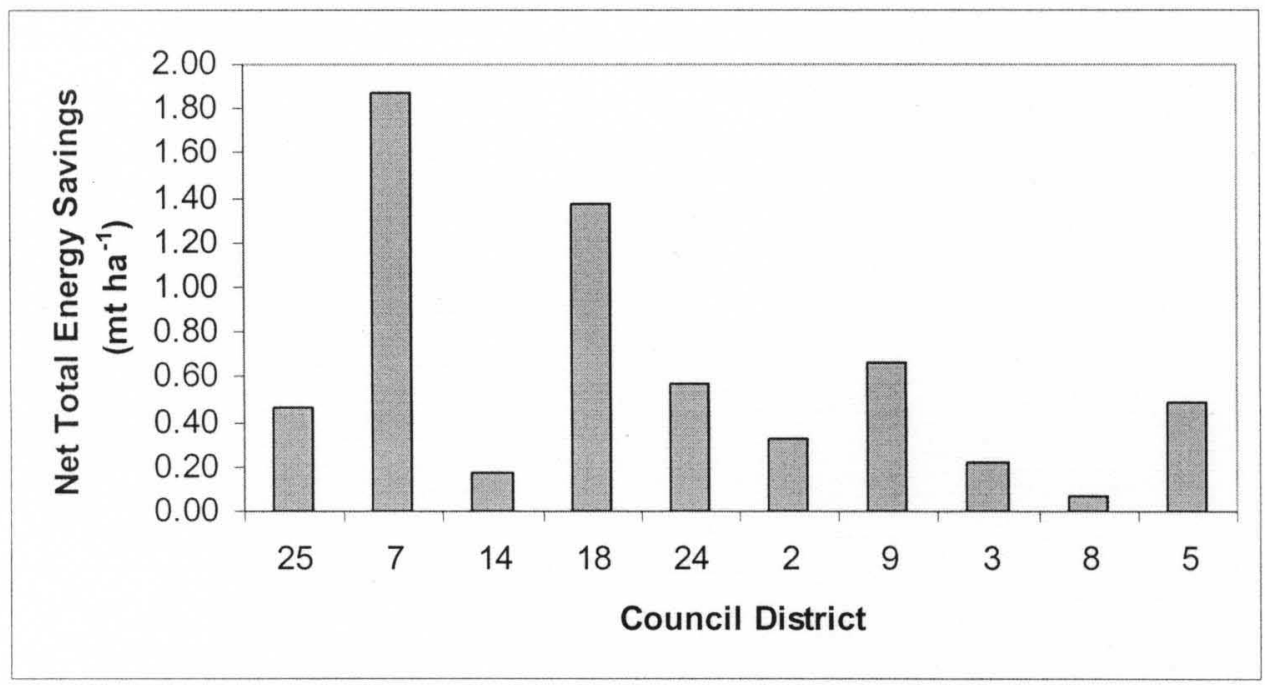

(b)

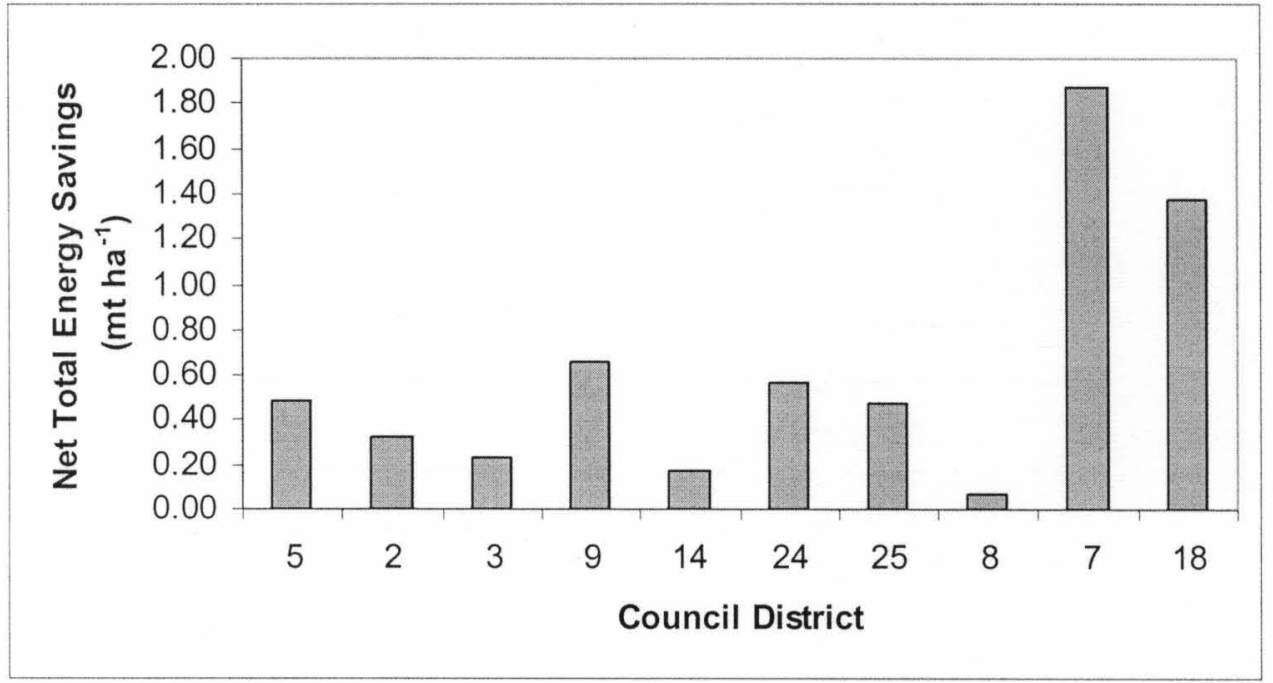

Figure 2-20: Net total tons of power plant carbon emissions avoided due to tree effects in residential land area of 10 council districts. Net total metric tons of carbon avoided: range: $0.06-1.85 \mathrm{mt} \mathrm{ha}^{-1}$; mean: $0.62 \mathrm{t} \mathrm{ha}^{-1} ; \mathrm{SE} \pm 0.18 \mathrm{mt} \mathrm{ha}^{-1}$. (a) Council districts arranged in ascending order by residential land area population density (people ha ${ }^{-1}$ ). Population density: range: 14.2 to 40.8 people $\mathrm{ha}^{-1}$; mean: 22.6; $\mathrm{SE} \pm 2.7$. (b) Council districts arranged in ascending order by council district median income: range: $\$ 24,500-\$ 58,600$; mean: $\$ 39,980$; $\mathrm{SE} \pm$ $\$ 3,300$. 


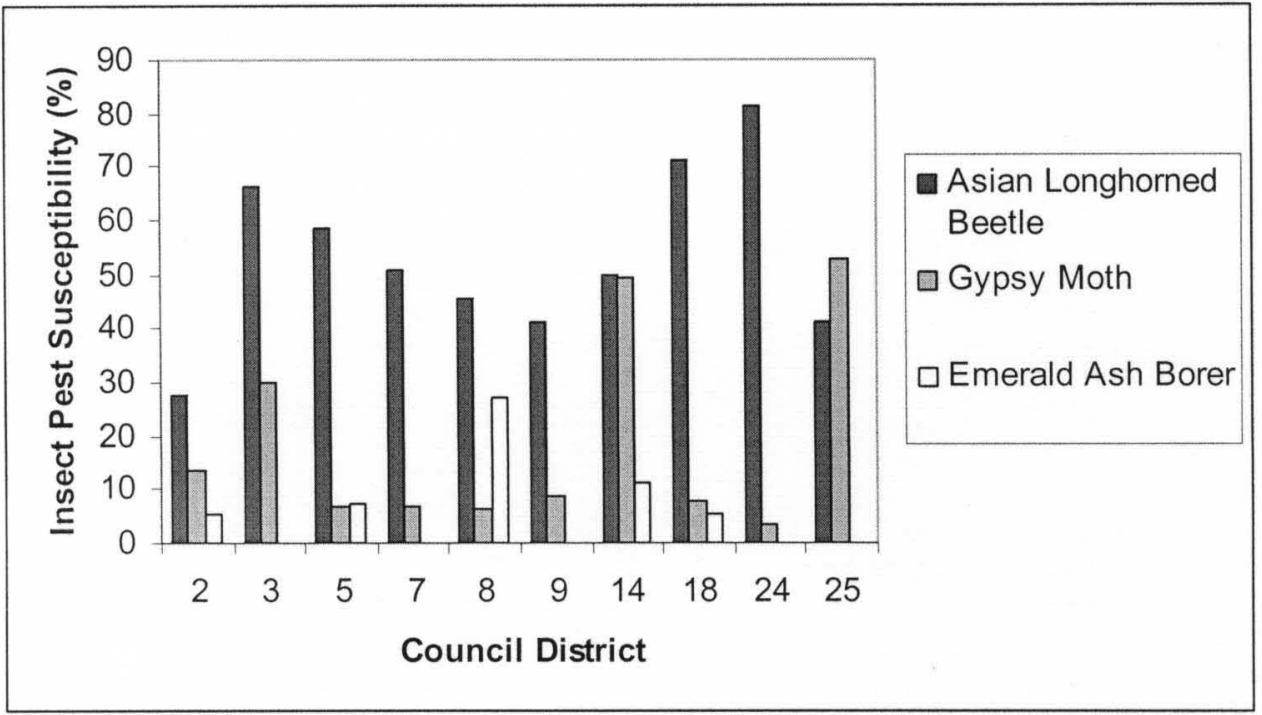

Figure 2-21: Percentage of trees susceptible to various insect pests in residential areas of 10 council districts

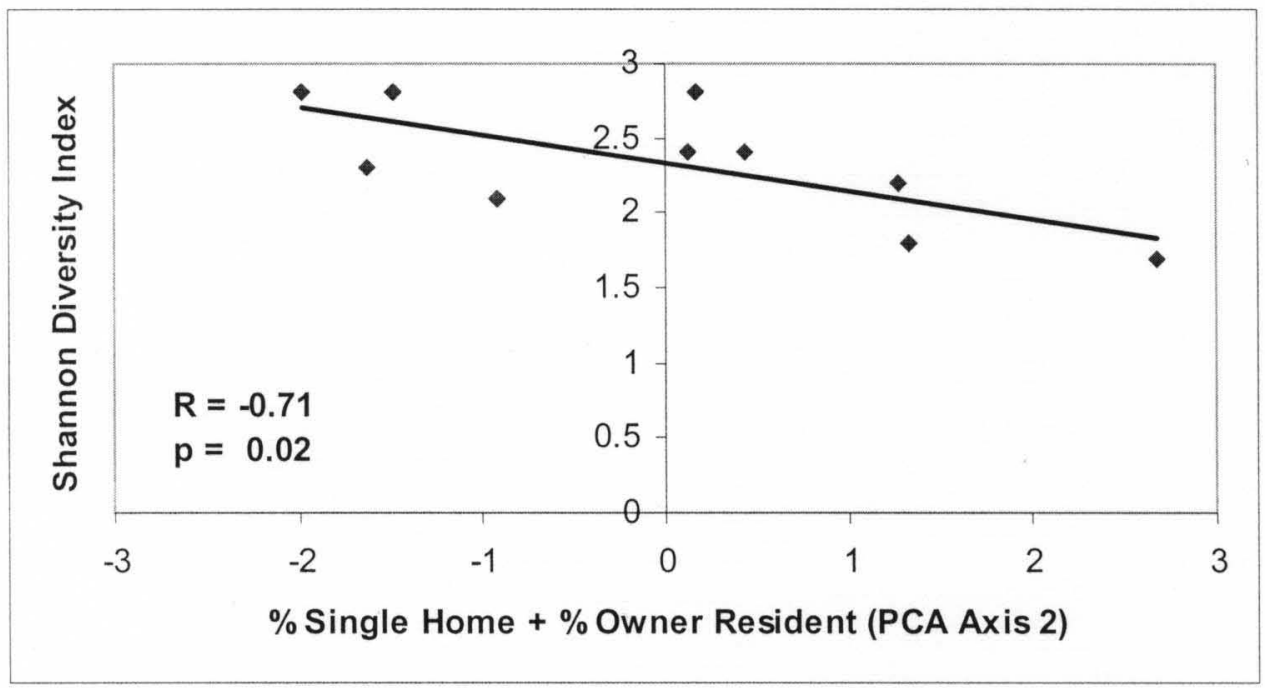

Figure 2-22: Pearson correlation $(\mathrm{R}=-0.71 ; \mathrm{p}<0.05)$ between axis 2 and Shannon Diversity Index for residential areas of 10 council districts 


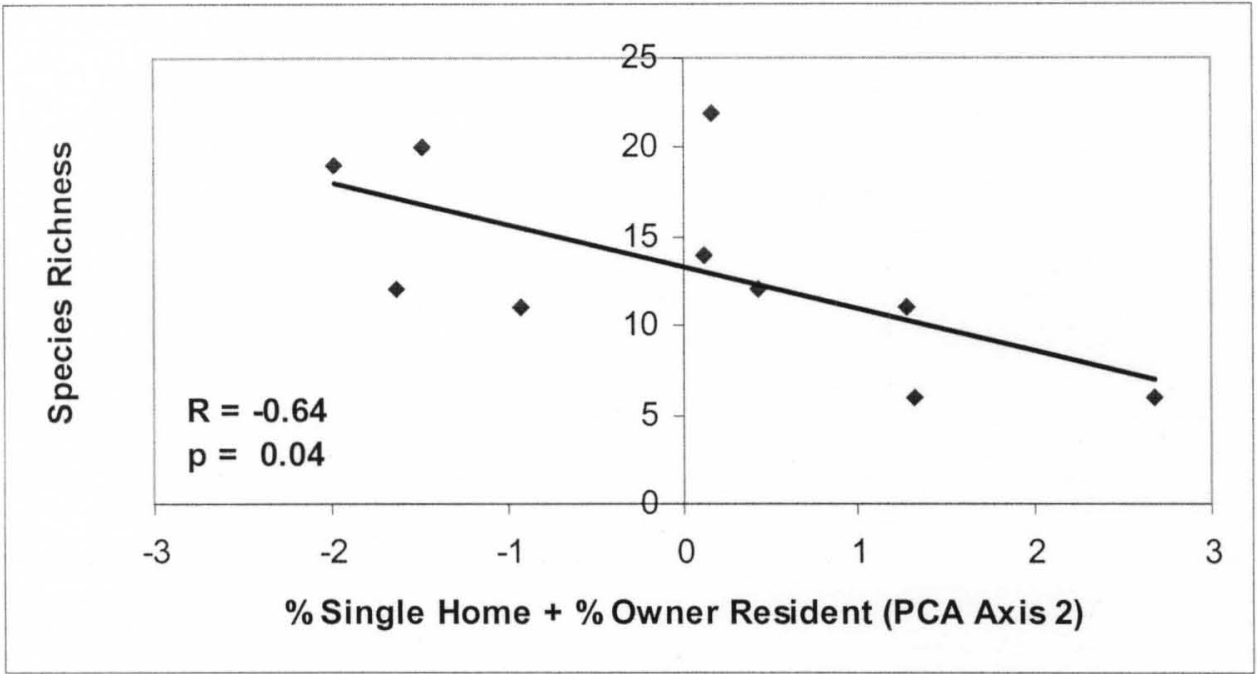

Figure 2-23: Pearson correlation $(\mathrm{R}=-0.64 ; \mathrm{p}<0.05)$ between axis 2 and species richness for residential areas of 10 council districts

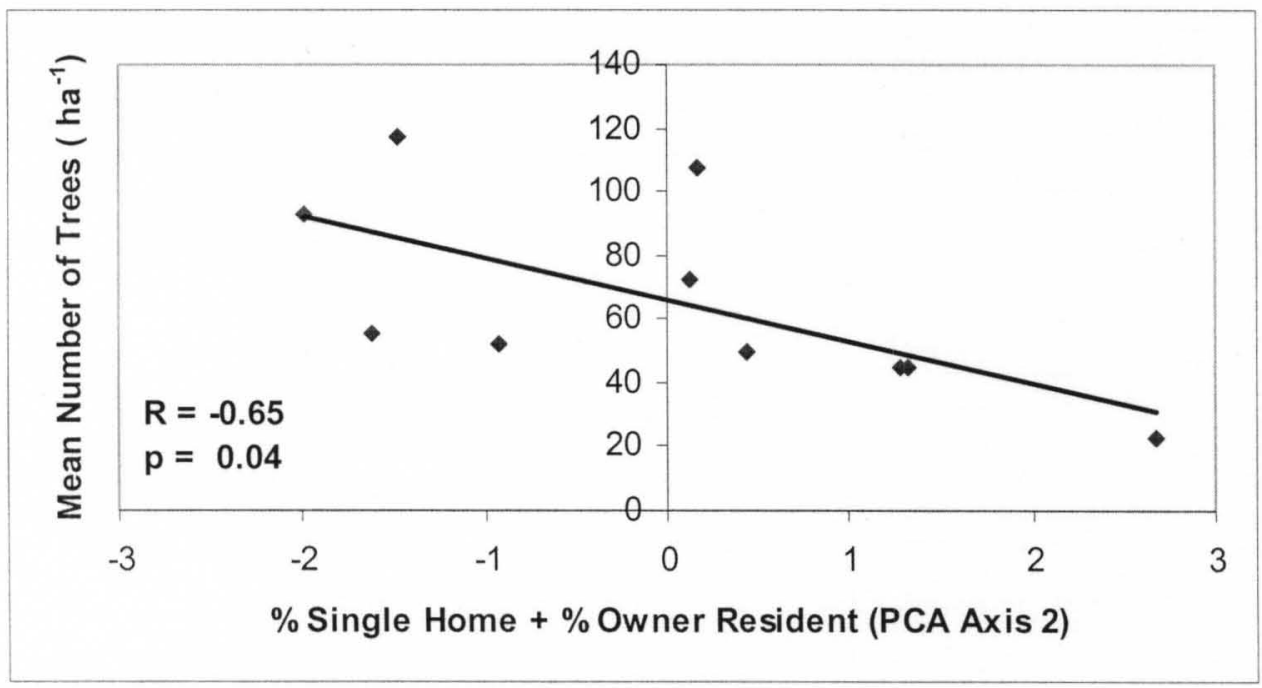

Figure 2-24: Pearson correlation $(\mathrm{R}=-0.65 ; \mathrm{p}<0.05)$ between axis 2 and mean number of trees per hectare for residential areas of 10 council districts 


\section{CHAPTER 3: EFFECTS OF TWO MAJOR STORM EVENTS ON RESIDENTIAL TREES IN LOUISVILLE, KY}

\section{INTRODUCTION}

Ecological disturbances involve sudden changes in resource availability in an ecosystem brought about by abiotic and biotic factors (Rogers 1996). In the case of the residential urban forest, such forces would include wind, ice storms, fire, and widespread outbreaks of pests and disease (Rogers 1996). Severe wind and ice storms can cause serious damage to urban trees (Gibbs and Grieg 1990; Sisinni et al. 1995). Trees provide many services to urban residents such as reducing the cost of heating and cooling buildings, decreasing air pollutants and particulate matter, ameliorating water quality, decreasing runoff into streams, and providing aesthetic enjoyment (Ziegler 1973; Rolfe 1974; Heisler 1986; Sanders 1986; Schroeder and Cannon 1987; Akbari et al. 1992). So, loss of residential trees due to storm or insect damage decreases the ecosystem service benefits trees provide urban residents. Trees also provide valuable wildlife habitat in urban areas, so their loss can also affect the abundance and distribution of local wildlife (Clark et al. 1997; Nowak and Dwyer 2007). Trees that fall during storms present hazards to human life as well as human property (Lopes et al. 2007). Because the urban residential forest is dependent on decisions made by lot owners for its continued existence, it is also important to understand how storm damage to trees and property might affect residents' attitudes toward trees (Duryea 1996). 
On September 14, 2008, the remnants of Hurricane Ike with gusts up to $120.7 \mathrm{~km} \mathrm{hr}^{-1}$ swept through the Louisville Metro area (http://www.crh.noaa.gov/lmk/?n=sep_14_08). Seventy-five percent of the population in Louisville, KY (301,000 out of 400,000 households) lost electric power (Kentucky Public Service Commission 2009). At the time, this storm caused the largest power outage in state history (Kentucky Public Service Commission 2009). The majority of the power line damage from this storm was attributed to falling trees or limbs (Kentucky Public Service Commission 2009). Then on January 26-28, 2009, an ice storm hit the region with ice accumulations of up to $5 \mathrm{~cm}$ on surfaces (National Weather Service http://www.crh.noaa.gov/lmk/?n=jan_2009_ice_and_snow). More than 200,000 households lost power in Louisville, KY during the ice storm. Statewide, this storm exceeded the damage caused by the Hurricane Ike storm just 4 months previously and caused the largest loss of power in Kentucky history (http://www.crh.noaa.gov/lmk/?n=jan_2009_ice_and_snow). Power line and transmission tower damage from this storm was primarily caused by the weight of the accumulated ice, but the problem was exacerbated by overburdened trees and limbs falling on the lines (Kentucky Public Service Commission 2009). The arrival of both of these storms so close together caused extensive damage to trees city-wide. According to the Louisville Public Works and Assets Department (Tammy Baum, Administrative Coordinator, personal communication), 15,468 metric tons (mt) of woody debris were collected by the city after the windstorm and 17,286 $\mathrm{mt}$ of woody debris were collected after the ice storm. These estimates of tree loss and damage would be conservative, 
because many residential, commercial and institutional lot managers also had trees removed or pruned by private contractors after each storm.

The storms provided an unprecedented opportunity in the summer of 2009 to return to the same plots surveyed in summer 2008 to assess tree damage and loss, and resident's attitudes toward trees after the storms. This study asked three main questions: 1) What changes occurred in tree communities after the storms?; 2) How did these changes translate into ecosystem service losses?; and 3) Did residents whose trees were affected by the storms plan to replace fallen and damaged trees?

\section{METHODS}

From June to August 2009, tree damage in the UFORE plots was assessed by return visits to 71 of the plots (for detailed methods, see Chapter 2 of this thesis). If a tree in the 2008 plot was missing or appeared to be damaged, residents were asked if this was due to the effects of the storms or whether the tree had been removed or damaged for non-storm related reasons. If a tree had been lost or removed due to storm damage effects, then the tree was deleted from the 2008 spreadsheet that had been sent to the USDA Forest Service that year and then sent again to the Forest Service in 2009 for recalculations of tree abundance, tree community characteristics and ecosystem service provision. If the tree in a UFORE plot suffered damage, but not loss, from the storms, then tree canopy measurements (canopy diameter, \% canopy missing, and \% dieback) were recorded and tree height measured if the tree had suffered damage to its upper limbs or canopy. Trees that were removed or damaged for reasons other than storm effects and trees in plots for which we were unable to contact the resident to ascertain the cause of 
tree damage or tree removal were left unchanged in the UFORE spreadsheet that was submitted to the USDA Forest Service after the 2009 field season. Since some of these trees may have been affected by the storms, leaving them in the 2009 tree inventory provided a conservative estimate of storm damage on residential trees. The data collected in summer 2009 were then submitted to the USDA Forest Service in Syracuse, NY, where they were run using the Urban Forest Effects (UFORE) model. This enabled us to assess damage to and loss of trees and their ecosystem services due to the combined effects of the September 2008 windstorm and the January 2009 ice storm. Any changes in tree community parameters after Hurricane Ike in September 2008 and the January 2009 ice storm were obtained by subtracting 2009 data from 2008 data on a per tree and per council district basis, depending on the analysis.

In addition, tree-loss and damage information at the entire yard-level (and not just the UFORE plot level) was collected in a survey administered to the residents where UFORE plot data had been collected (Table 3-1). Phone calls were made in June 2009 to residents for which we had this information. If we were unable to contact the resident by phone, then the surveys were delivered through the mail, via email, in person at the residence, or taped to the door if the resident was not home. The same survey questions were asked of all residents. If the UFORE plot did not contain trees, then only survey information was obtained to assess lot-owner/renter attitudes and management plans for any trees that had been affected in the entire yard. Data on the survey are reported in a descriptive manner and no statistical analyses were done on these responses to compare potential differences among council districts. 


\section{RESULTS}

\section{Impact of storms on Tree Community Structure}

The same 64 tree $(\mathrm{DBH}>2.54 \mathrm{~cm})$ species were identified in the 100 plots in residential areas of ten council districts in Louisville, KY (ten plots per council district) as were found in the 2008 study. The total number of trees sampled in the plots decreased by $3.8 \%$ from 264 in 2008 to 254 in 2009 . The mean estimated density of trees remaining across residential land use in all ten districts in summer 2009 was $6,120 \mathrm{~km}^{-2}$. The UFORE model estimated that in summer 2009 there were 793,291 trees in residential land of the 10 council districts, a decrease of 3.6\% from 2008 (Table 3-2). The 29,285 trees lost across all ten districts had a UFORE-estimated replacement value of $\$ 122,369,726$, a decrease in value of $5.9 \%$ from 2008 (Figure $3-1)$. The majority of the species found, $68.5 \%$, was native to Kentucky (a decrease of $1.7 \%$ from 2008). There were no changes in the representatives of the top ten most numerous tree species, although some species had fewer individuals than in 2008 (Table 3-3). The most numerous tree species in the plots remained Celtis occidentalis L. (Northern Hackberry; $11.0 \%$ of total). There was no change in the Shannon diversity index or in evenness from 2008.

Of the total number of trees, those in excellent condition decreased by $1 \%$ and those in good condition increased by $1 \%$ from 2008 figures. Trees in fair condition decreased by $1.3 \%$, trees in poor condition increased by $1.5 \%$ (from 0 ), and dead trees decreased by $0.15 \%$. Except for the change in dead trees, these changes most likely reflect the effects of storm damage on the health of the residential tree community. The decrease in the 
number of dead trees was driven by the removal of a previously dead tree in 2008 from one of the UFORE plots. Total leaf area susceptible to the Asian long-horned beetle decreased by $0.6 \%$, reflecting the loss of maple trees in the storms (Table 3-4).

Susceptibility to the gypsy moth increased by $0.8 \%$ and the emerald ash borer by $0.5 \%$, which reflects changing proportions of vulnerable trees in the total tree population. The Asian long-horned beetle preferentially attacks maple trees (Haack et al. 1997) and three of the top 11 most numerous species in the study areas were maples - Acer saccharum Marsh. (Sugar Maple; 6.3\% of total number of trees); Acer saccharinum L. (Silver or Water Maple; $5.5 \%$ of total); and Acer negundo L. (Boxelder; $3.1 \%$ of total).

Of the 264 trees found in the plots in 2008 , ten were removed and nine were damaged as a result of Hurricane Ike in September 2008 and the January 2009 ice storm. The ten trees that were removed had a diameter-at-breast-height (DBH) range of 5.1 to $107.4 \mathrm{~cm}$ with a mean $\mathrm{DBH}$ of $40.5 \mathrm{~cm}(\mathrm{SE}= \pm 11.1 \mathrm{~cm})$. The height range of the removed trees was 2.7 to $21.3 \mathrm{~m}$ with a mean height of $12.2 \mathrm{~m}(\mathrm{SE}= \pm 2.3 \mathrm{~m})$. These removed trees were found in five of the ten council districts and consisted of nine different species (Table 3-4). Four of the lost trees were all in the same plot in council district 18 and three of those trees, the Koelreuteria paniculata Laxm. (Goldenrain Tree) and two Tsuga canadensis (L.) Carr. (Eastern Hemlock) were knocked down by an $A$. negundo that fell during the Hurricane Ike storm. The nine damaged trees were found in six of the ten council districts and consisted of five different species (Table 3-5). Of the five species damaged, Acer species were the most damaged. Three of the nine (33.3\%) damaged trees were A. saccharum and two of the nine $(22.2 \%)$ were $A$. saccharinum. Ecosystem services provided to the residents of the ten council districts were adversely 
affected by the loss of and damage to these trees. A total of $5,471 \mathrm{~m}^{2}$ of leaf area was lost from the 19 damaged and removed trees, which represents a $7.9 \%$ decrease in canopy leaf area from that existing in 2008.

\section{Impact of Storms on Carbon Storage and Sequestration}

The UFORE model estimated that trees in the residential areas of the ten council districts in 2009 stored a total of 398,022 metric tons $(\mathrm{mt})$ of carbon $(\mathrm{SE}= \pm 71,499 \mathrm{mt})$. This represented a decrease of $4.2 \%$ from 2008. Council district 8 suffered the greatest percentage loss in carbon stored at 27\%. Council districts 5 and 18 sustained the next highest losses at $19.6 \%$ and $9.3 \%$, respectively. Council district 7 had the highest remaining carbon storage value at 71,578 $\mathrm{mt}(\mathrm{SE}= \pm 28,187 \mathrm{mt})$ and council district 5 the lowest at 8,675 $\mathrm{mt}(\mathrm{SE}= \pm 5,770 \mathrm{mt})$ (Table 3-6a). Total carbon sequestration in residential areas of the ten council districts was estimated at $12,931{\mathrm{mt} \mathrm{yr}^{-1}}^{(\mathrm{SE}}= \pm 2,032$

$\mathrm{mt}^{\mathrm{yr}}{ }^{-1}$ ). This represented a 3.8\% decrease in carbon sequestration services from 2008 . The greatest percentage loss in carbon sequestration $(17.1 \%)$ occurred in council district 8. Council districts 5 and 18 had the second and third highest reductions in carbon sequestration rates at $15.1 \%$ and $8.4 \%$, respectively. Council district 7 had the highest carbon sequestration rate remaining at 2,444 $\mathrm{mt} \mathrm{yr}^{-1}\left(\mathrm{SE}= \pm 866 \mathrm{mt} \mathrm{yr}^{-1}\right)$ and council district 5 the lowest rate at $342 \mathrm{mt} \mathrm{yr}^{-1}\left(\mathrm{SE}= \pm 223 \mathrm{mt} \mathrm{yr}^{-1}\right)($ Table 3-6b).

\section{Impact of Storms on Air Pollutant Removal}

UFORE calculated that the residential trees remaining after the two storms would remove $405 \mathrm{mt}$ of air pollutants annually in the 10 council districts, a decrease of $12.9 \%$ 
from 2008. This ecosystem service had a value in 2009 of $\$ 3,313,746$, a decrease of $2.6 \%$ from that in 2008. Ozone $\left(\mathrm{O}_{3}\right)$ was the pollutant with the highest removal rate $\left(224 \mathrm{mt}^{\mathrm{y}} \mathrm{r}^{-}\right.$

${ }^{1}$ ), but declined by $2 \%$ from 2008 estimates. The greatest pollutant removal decrease was in fine particulate matter with a diameter of less than $10 \mu \mathrm{m}\left(\mathrm{PM}_{10}\right)$ at $39 \%$ (Table 3-7). Pollutant removal by council district is shown in Table 3-8. Council district 7 had the highest estimated total pollutant removal remaining at 466,511 $\mathrm{kg}$ (7.8\% decrease), and council district 5 had the lowest at 49,961 $\mathrm{kg}(25.5 \%$ decrease $)$.

\section{Impact of storms on Energy Savings}

After the storms, the total estimated net energy usage avoided across all ten districts was 29,787 MWh, a decrease of 3.9\% from 2008. Council district 5 had the greatest loss in total net energy use avoided at 18.9\% (Figure 3-2a). UFORE also calculated carbon emissions avoided in metric tons of carbon $(\mathrm{mt} \mathrm{C}$ ) from coal-fired power plants due to reduced energy production loads on the power plant. The total net carbon emissions avoided was $8,758 \mathrm{mt} \mathrm{C}$, a $1.9 \%$ decrease from 2008 . Council district 8 sustained the largest loss of net carbon emissions avoided at 167.7\% (Figure 3-2b). According to the partitioning of this service into heating and cooling components in UFORE, this latter high value was due to a large increase in the amount of carbon emissions created due to increased heating as well as to a decrease in the amount of carbon emissions saved for cooling. Residents in these ten council districts saved \$1,906,368 in energy usage in 2009 due to tree influences, but this reflected a 3.9\% decrease in savings from 2008 (Figure 33). Council district 5 suffered the greatest loss in monetary savings with an $18.9 \%$ decrease from 2008 savings values. 


\section{Storm Damage Survey}

In the summer of 2009, a written and telephone survey was given to the residents of the 100 UFORE plots. The surveys were conducted for two reasons: 1) to obtain information on the extent of tree damage not only in the UFORE plots, but in the entire yard lot as well, and 2) to determine residents' plans for replanting after damage from the two major storms. Surveys were sent to residents of 87 of the UFORE plots. The remaining 13 plots were not included in the survey for the following reasons: the original UFORE plot occurred in an apartment complex; the resident had moved in after the storms occurred; or the house was empty and we no longer had contact information. Because many of the plots included more than one residential yard, we actually sent out a total of ninety-two surveys to the residents of the 87 UFORE plots included in the survey. In total, surveys from 75 yards were returned for an $81.5 \%$ return rate.

Of the 75 yards for which we obtained survey data, $71 \%$ suffered tree loss or damage (53 yards). Of the trees damaged or lost in the yards (not just the UFORE plots), 5.7\% were affected by Hurricane Ike only, $62.3 \%$ by the January 2009 ice storm only, and $32.1 \%$ were affected by both Hurricane Ike and the ice storm. Only $33 \%$ of those surveyed said they had already planted trees to replace ones lost or planned to replace trees in the next year. Of the remaining $67 \%$ who said they did not plan to plant any trees, their reasons for not planting fell into seven main categories: 1) have enough trees: $45.7 \% ; 2$ ) trees too much trouble: $17.1 \% ; 3$ ) people too old to plant or enjoy a new tree: $11.4 \%$; 4) like the way it looks without the tree: $8.6 \%$; 5) house for sale or rental: $8.6 \%$;

6) had planted trees before the storms and didn't plan to plant anymore for awhile: 5.7\%; 7) waiting to see if damaged tree survives: $2.9 \%$ (Table 3-9). 


\section{DISCUSSION}

The two storms, Hurricane Ike and the January 2009 ice storm, occurred after the conclusion of data collection for the 2008 field season. The tree damage caused by first wind and then ice provided us with the opportunity to collect new data during return visits to the UFORE plots in the summer of 2009 . We were then able to analyze these data to learn how these natural disturbances had affected the structure and function of the residential urban forest in the ten council districts, as well as to determine what residents' attitudes were after these storms. Since we did not conduct a survey in 2008 on residential attitudes about their trees, we cannot know if the storms themselves affected those attitudes. However, it would be important to understand how disturbance damage affects home owners' feelings about the trees in their yards, because they make the decisions about whether or not to replace damaged or lost trees. In a natural forest, tree successional trajectory after disturbance is determined by natural factors like species composition of the viable seed bank and nutrients released into the soil, and the nature of the disturbance and the new resources that become available for trees (whether it was a storm or a fire, for instance) (Pickett and White 1985). In addition, damaged trees are more susceptible to later mortality and further damage from fungal diseases and insect pests (Amman and Ryan 1991; Rogers 1996), so mortality in both natural and urban forests can continue for years after the initiating event. In an urban yard setting, these later biotic threats could further reduce the number of residential trees for years after the initial wind and ice storm disturbance. In residential areas, individual lot owners determine tree replacement and therefore, the successional trajectory of the urban forest as a whole with their tree planting decisions. This has implications for the continued 
existence of the residential urban forest and the ecosystem services it provides, if tree mortality rate exceeds replacement rate, or if smaller tree species are disproportionately replanted in lieu of larger tree species that formerly occupied that location.

As a result of the two storms, $3.8 \%$ of the residential trees in the ten council districts in Louisville, KY were lost and an additional 3.4\% were damaged. In a 1991 ice storm in Rochester, New York, 5.8\% of the city's street trees suffered $75 \%$ or greater canopy loss (from ice damage or remedial pruning due to the damage), while an additional $14.7 \%$ of the street trees suffered 50 to $74 \%$ canopy loss (Sisinni et al. 1995). The Rochester study was conducted at a larger scale than ours as they surveyed 58,536 trees (Sisinni et al. 1995), while there were only 264 trees in our plots. The majority of the most severely (75\%) and least severely (61\%) damaged trees in Rochester had diameters-at-breast-height (DBH) of $46 \mathrm{~cm}$ or less (Sisinni et al. 1995). Of the nine trees damaged in our UFORE plots, all had a DBH of less than $46 \mathrm{~cm}$ with a mean DBH of $24.9 \mathrm{~cm}(\mathrm{SE}= \pm 2.5 \mathrm{~cm})$. A total of ten trees were removed from our plots and $50 \%$ of those had a DBH of less than $46 \mathrm{~cm}$ (mean DBH $40.5 \mathrm{~cm}$; SE $= \pm 11.1 \mathrm{~cm}$ ). However, based on the data, it appears that this size class was not preferentially lost since trees of $45.7 \mathrm{~cm} \mathrm{DBH}$ or less made up a total of $72 \%$ all trees inventoried in 2008. In another study of 10,713 street trees, Hauer et al. (1993) found that an ice storm that hit Urbana, Illinois in 1990 damaged $26 \%$ of the trees. Seventeen percent of these trees were so severely damaged that they had to be removed or repaired immediately. The trees that had to be removed or repaired represented $4.6 \%$ of the total street tree population (Hauer et al. 1993) and the majority of those damaged (82\%) had a DBH of $33 \mathrm{~cm}$ or greater. 
The UFORE model estimated that the residential areas in the ten council districts lost a combined total of 29,286 trees in the Hurricane Ike and the January 2009 ice storm. The loss of these trees meant that key ecosystem services were affected as well. Leaf area lost due to tree damage and loss from both storms was more than $5,000 \mathrm{~m}^{2}$ across the ten council districts. Tree canopies are responsible for carbon sequestration, pollutant removal, and shade cooling services (Ziegler 1973; Rolfe 1974; Heisler 1986; Sanders 1986; Akbari et al. 1992). Since leaf area is an estimate of the surface area available for these services, any losses in leaf area also cause decreases in ecosystem services. Between 2008 and 2009, carbon storage and sequestration decreased by $4.2 \%$ and $3.8 \%$, respectively. Tree pollutant removal services decreased by $12.9 \%$ and energy savings by $3.9 \%$ from the 2008 levels. I could find no other studies that quantified ecosystem service losses after natural disturbances, so the data collected after these storms provide an estimate of how storm disturbances impact not just the trees themselves, but the services that they provide to urban residents.

We used a survey to assess tree storm damage at the entire lot level and to capture residents' attitudes toward replanting lost or damaged trees after the storms. As stated earlier, we distributed 92 surveys of which 75 were returned ( $81.5 \%$ return rate). Of the residents who returned their surveys, $71 \%$ of them reported tree damage or loss in their yards, as opposed to the UFORE plots, which encompass only a small portion of a yard, capturing a $7 \%$ frequency of tree loss and $8 \%$ frequency of tree damage in lots across the ten districts. In a survey given to 406 homeowners (32\% return rate) in 1993, Duryea et al. (1996), found that $38 \%$ of homeowners surveyed in Dade County, Florida had trees uprooted or broken by winds from Hurricane Andrew. Syracuse, New York was hit with 
winds of $150 \mathrm{mph}$ on September 7, 1998 that caused extensive tree and property damage (Palmer 2001). A survey given to 223 residents of the city (450 surveys sent out; $49.6 \%$ return rate) assessed tree damage in yards and if residents were in favor of street tree plantings (Palmer 2001). Of the respondents, $47 \%$ of them reported trees being damaged in their front yards and 67\% reported damage to trees in their side or back yards (Palmer 2001). Most of the surveyed residents stated that they favored the planting of more street trees (Palmer 2001). Neither one of these surveys assessed whether residents who lost trees in their yards had any plans to replace them. In our survey, only $33 \%$ of the respondents stated that they planned to replant trees lost from their yards and a variety of tree species were mentioned as potential candidates (Table 3-10). Six of the eleven species mentioned are native to Kentucky, one is native to the U.S., and there was insufficient information for the other four to determine native or exotic origin. Six of these species are also tall, shade trees. This information is important, because it indicates whether this part of the urban forest will be maintained at pre-storm levels or not and also whether trees replanted have the potential to maximize lost ecosystem services over time.

\section{CONCLUSION}

Storm disturbances to the urban residential forest not only cause damage to trees and property, but also have negative effects on the ecosystem services provided by these trees. Using the UFORE model, we had a unique opportunity not only to capture changes in tree community data and health before and after these two closely spaced storm events, but also estimate the ecosystem services lost due to residential tree loss and damage. This enabled us to estimate tree damage and ecosystem service loss for a subset of residential 
areas in Louisville, Kentucky. Of special note, Council district 5 has the highest residential population density at 4,044 people $\mathrm{km}^{2}$ and the lowest median income at $\$ 24,500$. The residents of this council district started with the fewest residential trees in 2008 , but suffered the highest percent loss of trees. This discrepancy in tree cover leads to decreased ecosystem services, such as energy savings and pollutant removal. Such disproportionate tree losses without timely replacement can be considered an environmental injustice if trees occurred in rental property or public rights-of-way, or if owners cannot afford to replace trees lost. Only $54 \%$ of the house units in council district 5 were owner-occupied, which ranked it $8^{\text {th }}$ out of the ten council districts for owner occupancy rates. High rates of rentership have been found to be negatively correlated with residential tree canopy cover (Perkins et al. 2004). Future tree replacement activities should focus on this underserved population.

The tree storm damage survey allowed us to capture the attitudes of a small number of residents toward tree replacement after these disturbances. Duryea (1997) makes the point that after hurricanes, residents often view trees as being problematic, but that it is important to educate them on the important services that trees provide and on proper tree selection and maintenance. It is imperative to understand residents' attitudes toward replacing lost or damaged trees in their yards, so that barriers to replanting might be addressed by improved education and to the creation and funding of government programs that could reduce such barriers, particularly after storm events. Educational outreach programs that teach urban residents about the ecosystem services provided by trees and on tree care and selection need to increase their activities and visibility particularly after storm events. Obtaining survey data at the council district or 
neighborhood scales about replanting attitudes may allow some fine-tuning for educational programs and policies needed to enhance tree planting in yards. Conducting a larger survey at such scales on residents' attitudes toward trees in various urban settings (e.g., yards, parks, and public-rights-of-way) would provide a more powerful data base for investigating whether relationships exist between their attitudes and sociodemographic and housing variables, such as median income and education level (see Chapter 2). Reasons for not replanting vary person to person, but such studies may reveal opinion trends by neighborhood and by socio-demographic categories. Knowledge of these differences could inform urban forest managers and policy makers so they could create policies tailored for different neighborhoods for lowering specific barriers needed for replanting and maintaining trees. 


\section{Tree Storm Damage Survey Questions}

1) Have any of the trees in your yard fallen or been severely damaged since last summer?

2) If so, do you know what kind of tree it was? Was it large or small?

3) Did the tree fall or become damaged during Hurricane Ike?

4) Did the tree fall or become damaged during the January Ice Storm?

5) Have you replaced or do you plan to replace any trees in the next year?

6) If not, why not?

7) If so, then what kind of tree are you considering planting? Why that particular type of tree?

Table 3-1: Survey questions administered to UFORE plot residents

Table 3-2: UFORE-estimated tree loss by Hurricane Ike and the January 2009 ice storm in 10 Louisville council districts.

\begin{tabular}{|c|r|r|r|}
\hline $\begin{array}{c}\text { Council } \\
\text { District }\end{array}$ & $\begin{array}{c}\text { Number of } \\
\text { Trees in } \\
\mathbf{2 0 0 8}\end{array}$ & $\begin{array}{c}\text { Number of } \\
\text { Trees in 2009 }\end{array}$ & $\begin{array}{c}\text { Change in } \\
\text { Number of } \\
\text { Trees (\%) }\end{array}$ \\
\hline $\mathbf{2}$ & 59,026 & 56,343 & -4.5 \\
\hline $\mathbf{3}$ & 48,224 & 48,224 & 0.0 \\
\hline $\mathbf{5}$ & 33,514 & 30,322 & -9.5 \\
\hline $\mathbf{7}$ & 125,111 & 120,797 & -3.4 \\
\hline $\mathbf{8}$ & 88,177 & 83,411 & -5.4 \\
\hline $\mathbf{9}$ & 131,483 & 131,483 & 0.0 \\
\hline $\mathbf{1 4}$ & 38,115 & 38,115 & 0.0 \\
\hline $\mathbf{1 8}$ & 154,044 & 139,714 & -9.3 \\
\hline $\mathbf{2 4}$ & 61,644 & 61,644 & 0.0 \\
\hline $\mathbf{2 5}$ & 83,238 & 83,238 & 0.0 \\
\hline $\begin{array}{c}\text { Total in } \\
\text { Residential } \\
\text { Land Use } \\
\text { (10 council } \\
\text { districts) }\end{array}$ & & & \\
\hline
\end{tabular}


Table 3-3: The top 11 tree species in residential areas of the 10 council districts in the summer of 2009 , including percent change in number of trees

from the summer of 2008 to the summer of 2009 . Hurricane Ike came through Metro Louisville in September 2008 and a significant ice storm hit in January 2009. Tree data from the summer of 2008 were collected between May and July, prior to the first of these storms. Changes in the summer of 2009 data reflect trees that were damaged or removed due to damage from these storms. The top 11 species were included in this table, because the final three each had 8 representatives.

\begin{tabular}{|l|c|c|c|c|}
\hline \multicolumn{1}{|c|}{ Species } & Family & $\begin{array}{c}\text { Individual } \\
\text { Frequency }\end{array}$ & $\begin{array}{c}\text { Cumulative } \\
\text { Frequency } \\
\text { Percent }\end{array}$ & $\begin{array}{c}\text { Change in } \\
\text { Individual } \\
\text { Frequency } \\
\text { (\%) }\end{array}$ \\
\hline Celtis occidentalis & Ulmaceae & 28 & 11.0 & -3.4 \\
\hline Acer saccharum & Aceraceae & 16 & 17.3 & 0 \\
\hline Acer saccharinum & Aceraceae & 14 & 22.8 & -6.7 \\
\hline Cercis canadensis & Fabaceae & 12 & 27.6 & 0 \\
\hline Morus rubra & Moraceae & 11 & 31.9 & 0 \\
\hline Cornus florida & Cornaceae & 10 & 35.8 & -9.1 \\
\hline Malus species ${ }^{\text {a, }}$ & Rosaceae & 9 & 39.4 & 0 \\
\hline Morus alba & Moraceae & 9 & 42.9 & 0 \\
\hline Acer negundo & Aceraceae & 8 & 46.1 & -11.1 \\
\hline $\begin{array}{l}\text { Fraxinus } \\
\text { pennsylvanica }\end{array}$ & Oleaceae & 8 & 49.2 & -11.1 \\
\hline Prunus serotina & Rosaceae & 8 & 52.4 & 0 \\
\hline & & & & \\
\hline Fraxinus americana** & Oleaceae & $(3)$ & 53.5 & \\
\hline & & & & \\
\hline Sum & & $\mathbf{1 3 6}$ & & \\
\hline $\begin{array}{l}\text { Total of } 64 \text { Sampled } \\
\text { Species }\end{array}$ & & $\mathbf{2 5 4}$ & & \\
\hline
\end{tabular}

${ }^{\mathrm{a}}$ Malus sp. = Crab Apples

e exotic species

**Note: $F$. americana is not the $12^{\text {th }}$ most common tree; it is included due to Emerald Ash Borer susceptibility 
Table 3-4: Individual trees lost during Hurricane Ike in September 2008 and/or the ice storm in January 2009. The last four trees in council district 18 were all in the same plot.

\begin{tabular}{|l|c|c|c|}
\hline \multicolumn{4}{|c|}{ Trees Lost Due to Storm Damage } \\
\hline \multicolumn{1}{|c|}{ Species } & $\begin{array}{c}\text { Council } \\
\text { District }\end{array}$ & $\begin{array}{c}\text { DBH } \\
\text { (cm) }\end{array}$ & $\begin{array}{c}\text { Height } \\
\text { (m) }\end{array}$ \\
\hline $\begin{array}{l}\text { Fraxinus } \\
\text { pennsylvanica }\end{array}$ & 2 & 48.5 & 19.5 \\
\hline Acer saccharinum $^{*}$ & 5 & 72.4 & 20.4 \\
\hline Cornus florida $^{*}$ & 5 & 11.1 & 4 \\
\hline Pinus taeda & 7 & 20.6 & 9.9 \\
\hline Celtis occidentalis $^{*}$ & 8 & 107.4 & 21.3 \\
\hline Pinus strobus & 8 & 70.1 & 17.7 \\
\hline Acer negundo & 18 & 52.1 & 13.7 \\
\hline $\begin{array}{l}\text { Koelreuteria } \\
\text { paniculata }\end{array}$ & 18 & 10.2 & 7 \\
\hline Tsuga canadensis & 18 & 5.1 & 2.7 \\
\hline Tsuga canadensis & 18 & 7.9 & 5.5 \\
\hline
\end{tabular}

* One of top 11 most numerous species.

Table 3-5: Individual trees that sustained damage during Hurricane Ike in September 2008 and/or during the ice storm in January 2009.

\begin{tabular}{|c|c|c|}
\hline \multicolumn{3}{|c|}{ Trees Damaged in Storms } \\
\hline Species & $\begin{array}{l}\text { Council } \\
\text { District }\end{array}$ & Damage \\
\hline Acer saccharum* & 2 & $\begin{array}{l}\text { Decreased height and crown (canopy) } \\
\text { measurements }\end{array}$ \\
\hline Morus rubra* & 5 & $\begin{array}{l}\text { Decreased height and crown (canopy) } \\
\text { measurements }\end{array}$ \\
\hline Morus rubra* & 5 & Decreased crown (canopy) measurements \\
\hline Acer saccharum* & 7 & Decreased crown (canopy) measurements \\
\hline Acer saccharum* & 7 & Increased percent of canopy missing \\
\hline Tilia europaea & 9 & $\begin{array}{l}\text { Decreased height and crown (canopy) } \\
\text { measurements; Increased percent of } \\
\text { canopy missing }\end{array}$ \\
\hline Prunus serotina* & 14 & $\begin{array}{l}\text { Increased percent of canopy missing and } \\
\text { increased percent dieback }\end{array}$ \\
\hline Acer saccharinum* & 24 & $\begin{array}{l}\text { Decreased crown (canopy) measurements; } \\
\text { Increased percent of canopy missing }\end{array}$ \\
\hline Acer saccharinum* & 24 & Decreased crown (canopy) measurements \\
\hline
\end{tabular}

* One of top 11 most numerous species. 
Table 3-6: Changes in (a) carbon storage (metric tons) and (b) carbon sequestration (metric tons $\mathrm{yr}^{-1}$ ) from 2008 to 2009 after the loss of trees in Hurricane Ike and the January 2009 ice storm. Sorted in order from least to greatest loss

(a)

\begin{tabular}{|c|c|c|r|}
\hline $\begin{array}{c}\text { Council } \\
\text { District }\end{array}$ & $\begin{array}{c}\text { 2008 Carbon } \\
\text { Storage } \\
\text { (tons) }\end{array}$ & $\begin{array}{c}\text { 2009 Carbon } \\
\text { Storage } \\
\text { (tons) }\end{array}$ & $\begin{array}{c}\text { Carbon Storage } \\
\text { Change (\%) }\end{array}$ \\
\hline $\mathbf{3}$ & 28,231 & 28,231 & 0 \\
\hline $\mathbf{9}$ & 22,436 & 22,436 & 0 \\
\hline $\mathbf{1 4}$ & 46,490 & 46,490 & 0 \\
\hline $\mathbf{2 4}$ & 44,829 & 44,829 & -0.2 \\
\hline $\mathbf{2 5}$ & 68,545 & 68,545 & -2.0 \\
\hline $\mathbf{7}$ & 71,752 & 71,578 & -9.3 \\
\hline $\mathbf{2}$ & 52,821 & 51,757 & -19.6 \\
\hline $\mathbf{1 8}$ & 26,998 & 24,485 & -27.0 \\
\hline $\mathbf{5}$ & 10,794 & 8,675 & \\
\hline $\mathbf{8}$ & 42,430 & 30,995 & -4.2 \\
\hline $\begin{array}{c}\text { Total for } \\
\text { Residential } \\
\text { Land Use } \\
\text { (10 council } \\
\text { districts) }\end{array}$ & & & \\
\hline
\end{tabular}

(b)

\begin{tabular}{|c|c|c|c|}
\hline $\begin{array}{l}\text { Council } \\
\text { District }\end{array}$ & $\begin{array}{l}2008 \text { Carbon } \\
\text { Sequestration } \\
\left(\text { tons } \mathrm{yr}^{-1}\right)\end{array}$ & $\begin{array}{l}2009 \text { Carbon } \\
\text { Sequestration } \\
\left.\text { (tons } \mathrm{yr}^{-1}\right)\end{array}$ & $\begin{array}{c}\text { Carbon } \\
\text { Sequestration } \\
\text { Change }(\%)\end{array}$ \\
\hline 3 & 574.60 & 575 & 0 \\
\hline 9 & $1,021.41$ & 1,021 & 0 \\
\hline 14 & $1,433.08$ & 1,433 & 0 \\
\hline 24 & $1,220.54$ & 1,221 & 0 \\
\hline 7 & $2,459.00$ & 2,444 & -0.6 \\
\hline 2 & $1,612.74$ & 1,580 & -2.0 \\
\hline 25 & $2,037.40$ & 1,980 & -2.8 \\
\hline 18 & $1,350.70$ & 1,237 & -8.4 \\
\hline 5 & 402.27 & 342 & -15.1 \\
\hline 8 & $1,326.54$ & 1,100 & -17.1 \\
\hline $\begin{array}{l}\text { Total for } \\
\text { Residential } \\
\text { Land Use } \\
\text { (10 council } \\
\text { districts) }\end{array}$ & $13,438.29$ & 12,931 & -3.8 \\
\hline
\end{tabular}


Table 3-7: Changes in metric tons of specific and total pollutants removed by trees from 2008 to 2009.

\begin{tabular}{|c|c|c|c|}
\hline Pollutant & $\begin{array}{l}2008 \\
(\mathrm{mt})\end{array}$ & $\begin{array}{l}2009 \\
(\mathrm{mt})\end{array}$ & $\begin{array}{l}\text { Change in } \\
\text { Pollutants } \\
\text { removed }(\%)\end{array}$ \\
\hline $\mathrm{CO}$ & 2.4 & 2.4 & 0 \\
\hline $\mathrm{NO}_{2}$ & 42.9 & 41.5 & -3.2 \\
\hline $\mathrm{O}_{3}$ & 228.5 & 224.0 & -2.0 \\
\hline $\mathrm{PM}_{10}$ & 136.3 & 83.0 & -39.1 \\
\hline $\mathrm{SO}_{2}$ & 55.4 & 54.5 & -1.6 \\
\hline Total & 465.4 & 405.3 & -12.9 \\
\hline
\end{tabular}

Table 3-8: Total amount of pollutants removed $(\mathrm{kg})$ in the residential areas of 10 council districts

\begin{tabular}{|c|r|}
\hline Council District & Total Pollutants Removed (kg) \\
\hline $\mathbf{2}$ & 302,456 \\
\hline $\mathbf{3}$ & 134,161 \\
\hline $\mathbf{5}$ & 49,961 \\
\hline $\mathbf{7}$ & 466,511 \\
\hline $\mathbf{8}$ & 168,089 \\
\hline $\mathbf{9}$ & 216,291 \\
\hline $\mathbf{1 4}$ & 153,297 \\
\hline $\mathbf{1 8}$ & 177,812 \\
\hline $\mathbf{2 4}$ & 232,738 \\
\hline $\mathbf{2 5}$ & 239,358 \\
\hline Total & $2,140,779$ \\
\hline
\end{tabular}


Table 3-9: Tree storm damage survey information by council district

\begin{tabular}{|c|c|c|c|c|}
\hline $\begin{array}{l}\text { Council } \\
\text { District }\end{array}$ & $\begin{array}{l}\text { Number } \\
\text { Trees } \\
\text { Lost or } \\
\text { Removed } \\
\text { Due to } \\
\text { Storms }\end{array}$ & $\begin{array}{l}\text { Number } \\
\text { Trees } \\
\text { Damaged } \\
\text { by } \\
\text { Storms }\end{array}$ & $\begin{array}{l}\text { Surveys } \\
\text { Returned/ } \\
\text { Surveys } \\
\text { Distributed }\end{array}$ & $\begin{array}{c}\text { Reasons For Not } \\
\text { Planting/Replacing Trees }\end{array}$ \\
\hline 2 & 4 & $12+$ & $9 / 11$ & $\begin{array}{l}\text { "We don't want any trees" } \\
\text { "I have all I need" } \\
\text { "I have plenty; could do with 1-2 } \\
\text { less" } \\
\text { "No room; have lots of trees" } \\
\text { "House is for sale" }\end{array}$ \\
\hline 3 & $3+$ & 0 & $5 / 6$ & $\begin{array}{l}\text { "Don't need any more trees" } \\
\text { "We're too old" }\end{array}$ \\
\hline 5 & 3 & 4 & $5 / 8$ & $\begin{array}{l}\text { "The yard is the way I want it" } \\
\text { "I don't want any more trees; they're } \\
\text { too much trouble" }\end{array}$ \\
\hline 7 & 1 & $12+$ & $10 / 11$ & $\begin{array}{l}\text { "We have enough problems" } \\
\text { "Too old" } \\
\text { "I have plenty of trees" }\end{array}$ \\
\hline 8 & 4 & $4+$ & $8 / 9$ & $\begin{array}{l}\text { "Still have trees left \& they come } \\
\text { back, so no need to" } \\
\text { "There is another large pine next to } \\
\text { one lost \& don't need another one" } \\
\text { "I have all the trees I need" }\end{array}$ \\
\hline 9 & 10 & 7 & $8 / 9$ & $\begin{array}{l}\text { "Rental property, so won't plant trees. } \\
\text { Also, lots of property damage" } \\
\text { "Like the way it looks without it" } \\
\text { "Rental property; landlord feels } \\
\text { removed trees will keep raccoons } \\
\text { off of roof" } \\
\text { "Planted new trees last year \& that is } \\
\text { about the extent of planting trees" }\end{array}$ \\
\hline 14 & 2 & $5+$ & $8 / 10$ & $\begin{array}{l}\text { "Too much of a mess in the fall; } \\
\text { neighbors' trees give plenty of } \\
\text { shade" } \\
\text { "Don't need any more" } \\
\text { "Feel like I have enough" } \\
\text { "We have enough" } \\
\text { "Replace trees as needed; no plans } \\
\text { to plant any in next year" } \\
\text { "I'm too old (80) to enjoy a new tree" }\end{array}$ \\
\hline 18 & 5 & $7+$ & $6 / 8$ & $\begin{array}{l}\text { "Don't need to change any at this } \\
\text { time" } \\
\text { "Waiting to see what will happen } \\
\text { with a damaged tree" } \\
\text { "Not this year; we don't want to have } \\
\text { to fool with them" }\end{array}$ \\
\hline
\end{tabular}




\begin{tabular}{|l|l|l|l|l|}
24 & & $7+$ & $8 / 10$ & $\begin{array}{l}\text { "Planted 3 trees in last year" } \\
\text { "Had it with trees! Had to get roof } \\
\text { replaced from branch damage, so } \\
\text { going to remove the tree" } \\
\text { "I'm 80 years old \& not in the tree } \\
\text { planting business any more" }\end{array}$ \\
\hline 25 & 0 & $5+$ & $8 / 10$ & $\begin{array}{l}\text { "I like the look" } \\
\text { "I may replace some trees in 2-3 } \\
\text { years" } \\
\text { "Happy with what I've got" }\end{array}$ \\
\hline
\end{tabular}


Table 3-10: Trees listed in the storm damage survey as species the residents would consider planting as replacement trees after the storms.

\begin{tabular}{|l|l|l|l|r|}
\hline \multicolumn{2}{|c|}{ Replacement Tree Candidates } & $\begin{array}{c}\text { Native } \\
\text { to KY? }\end{array}$ & $\begin{array}{l}\text { Native to } \\
\text { U.S.? }\end{array}$ & $\begin{array}{c}\text { Ultimate Height } \\
\text { (m) }\end{array}$ \\
\hline Cotinus obovatus & American Smoketree & No & Yes & 9 \\
\hline Taxodium distichum & Bald-cypress & Yes & Yes & $30-37$ \\
\hline Juniperus species & Cedar & some & some & Depends on species \\
\hline Prunus species & Cherry & some & some & Depends on species \\
\hline Cornus florida & Flowering Dogwood & Yes & Yes & 9 \\
\hline Family: Rosaceae & Fruit trees & some & some & 21 \\
\hline Gymnocladus dioicus & Kentucky Coffeetree & Yes & Yes & $9-30$ \\
\hline Acer species & Maple & some & some & $15-27$ \\
\hline Quercus palustris & Pin Oak & Yes & Yes & $18-30$ \\
\hline Platanus occidentalis & Sycamore & Yes & Yes & $24-37$ \\
\hline Liriodendron tuilipifera & Tulip Poplar & Yes & Yes & \multicolumn{2}{|c|}{} \\
\hline
\end{tabular}


(a)

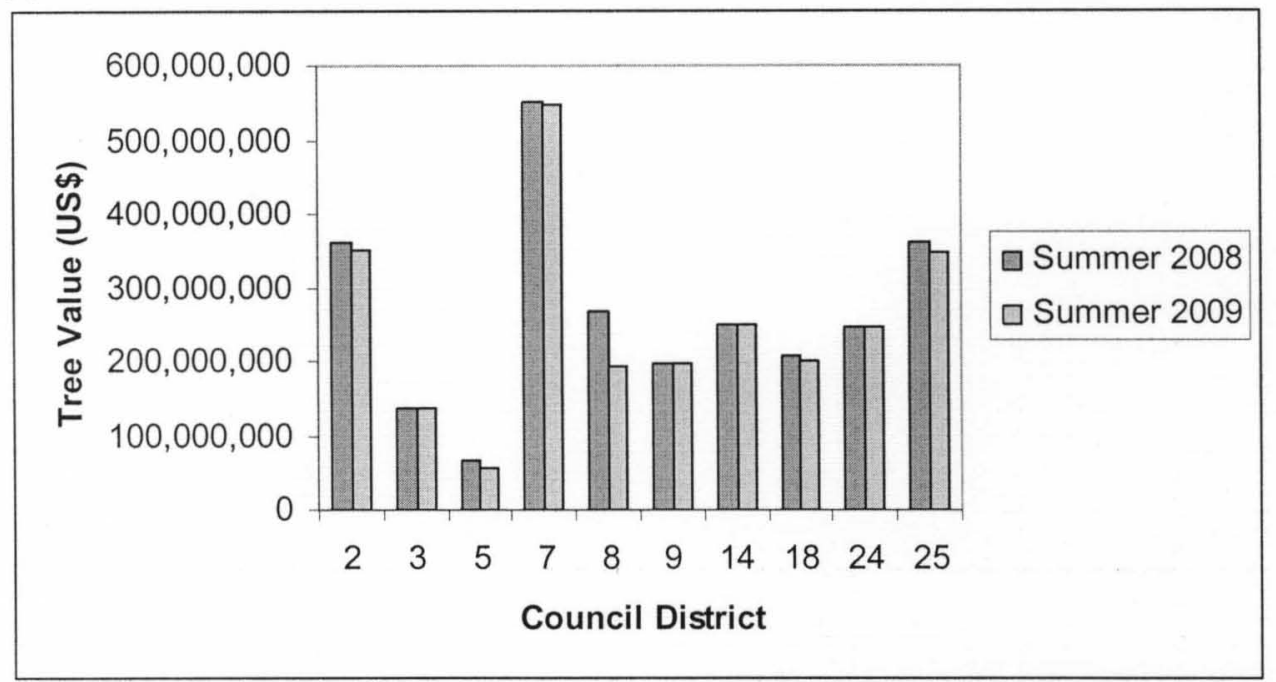

(b)

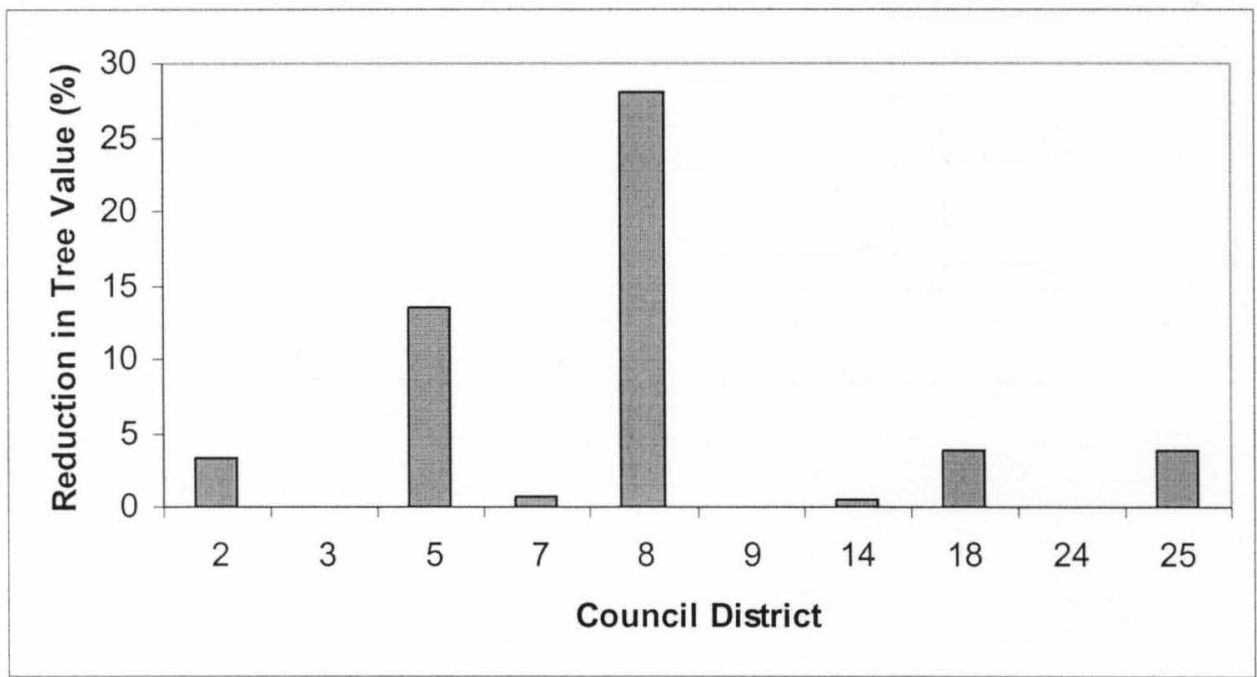

Figure 3-1: UFORE-estimated loss in tree value due to storm damage.

(a) Comparison of UFORE estimated tree value (US\$) per council district in 2008 and 2009. (b) Percent reduction in tree value from 2008 to 2009 by council district. 
(a)

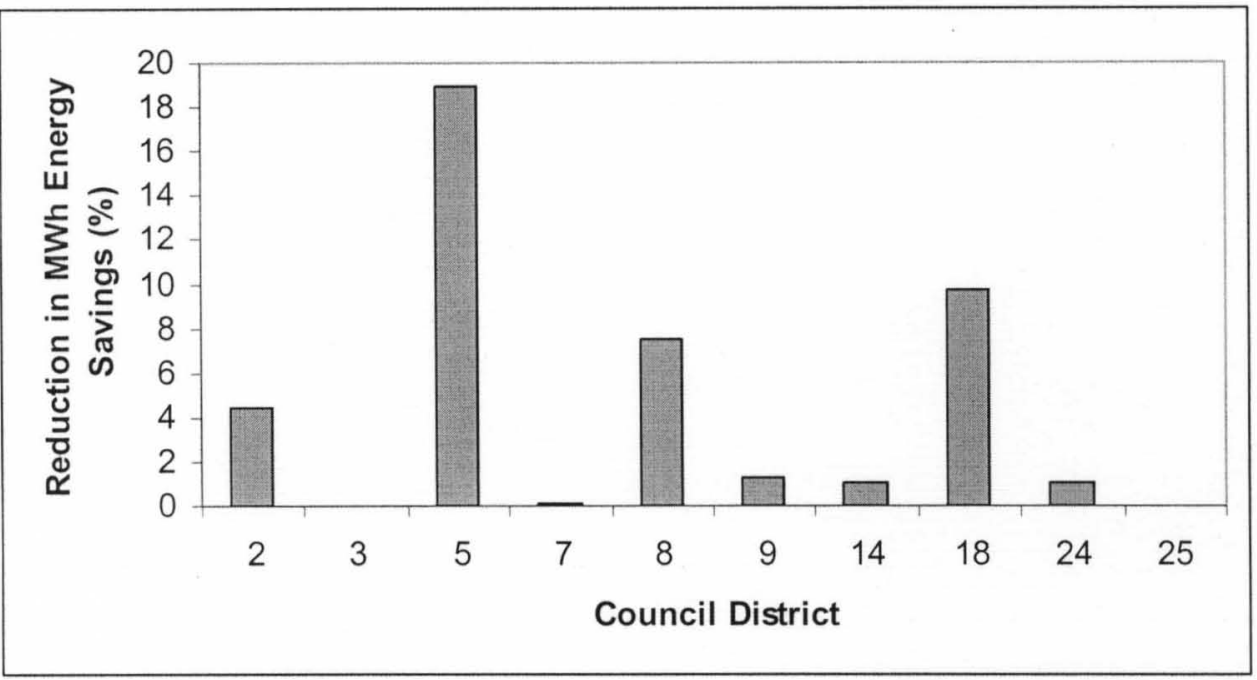

(b)

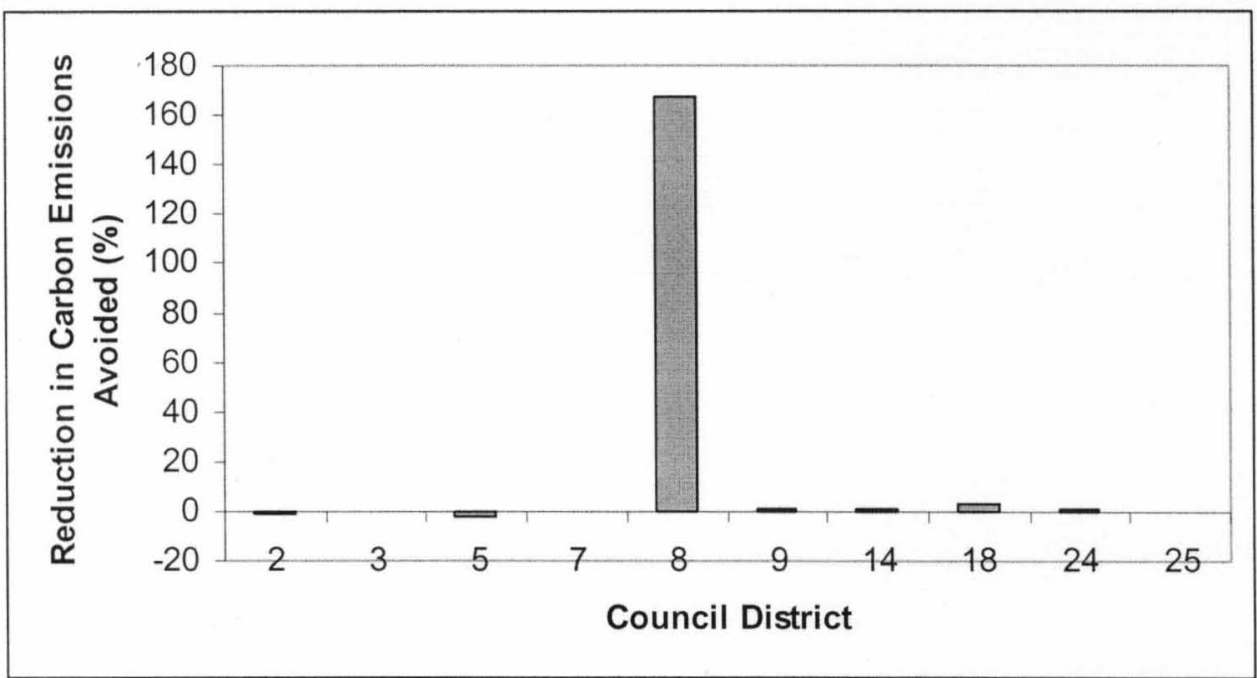

Figure 3-2: (a) Percent reduction in net energy savings in MWh and (b) Percent reduction in net carbon emissions avoided (metric tons) from fossil-fuel using power plants for residential areas of 10 council districts. Decreases in net energy savings and net carbon emissions avoided are due to tree damage and loss from the remnants of Hurricane Ike in September 2008 and the January 2009 ice storm. 


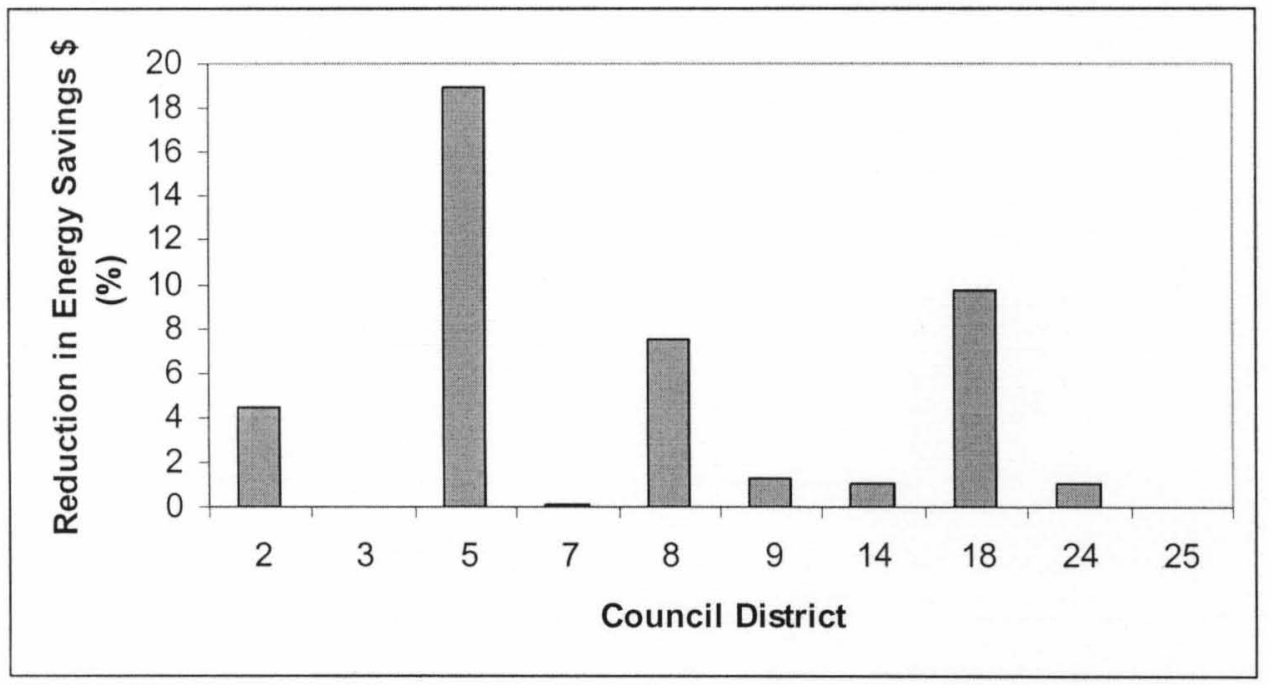

Figure 3-3: Percent losses in net energy savings in dollars for residential areas of 10 council districts. Decreases in net energy savings are due to tree damage and loss from the remnants of Hurricane Ike in September 2008 and the January 2009 ice storm 


\section{CHAPTER 4: CONCLUSION}

In chapter 2, we were successful in providing data on the tree assemblages and proportions of land cover elements in residential land use in ten of Louisville's council districts in 2008 and 2009. These data were also used to estimate several ecosystem services provided to people by their residential trees. As far as is known, information for tree communities and their ecosystem services has not been obtained for Louisville's urban forest before, and can provide a baseline for similar studies to determine change in urban forest structure in residential areas in the future.

At the larger city scale, municipalities have invested in green infrastructure, such as trees, in order to benefit from the perceived ecosystem services that urban vegetation provides (Pataki et al. 2011). Pataki et al. (2011) posit that some of the ecosystem services quantified by such models as UFORE are not as well supported by experimental data as assumed. Specifically, the authors state that there is little empirical evidence to support claims that urban vegetation effectively decreases air pollutant levels compared to the amounts emitted by urban ecosystems (Pataki et al. 2011). Data are available though, which support the positive effects of urban green infrastructure in reducing storm water runoff (Shuster et al. 2008), cooling environments (Akbari 2002; Simpson 2002), improving human psychological well-being (Korpela and Ylén 2007), and enhancing social relations at neighborhood scales (Vemuri et al. 2011). At this point in time, the 
UFORE model remains the best tool available for predicting ecosystem services provided by trees in urban areas.

Some of the strengths of the UFORE protocol are that it provides a methodology that permits standardization of sampling across cities and provides a valid statistical technique for comparative studies across cities and within them. We were also hoping to use the UFORE-estimated tree community and ecosystem service data to explore how these varied in relation to a set of socio-demographic and housing variables across the residential areas of the ten council districts. Unfortunately, we were not able to demonstrate many relationships between variation in socio-demographic and housing variables and tree community and ecosystem service variables at council district and smaller scales. Those that were statistically significant primarily related Axis 2 variables (\% single home; $\%$ owner resident) at the council district and Shannon diversity, species richness, and mean number of trees. Assuming that such relationships occur in this city, attempts to determine their existence would perhaps be more successful if tree information were collected at the larger lot level rather than just at the smaller UFORE plot level. In that way, more information could be gathered about the preferences of a particular lot manager (the resident or owner) that could then be related to social, demographic and housing stock variation. In addition, more UFORE plots may also have provided greater power to detect relationships between variation in various tree assemblage characteristics and differences in socio-demographics and housing at the district level. Larger scale tree cover obtained using Geographic Information Systems (GIS) and LOJIC aerial photographs would perhaps be more successful at examining the existence of those linkages since the scales are larger and more evenly matched to socio- 
demographic and housing data at the district scale. However, such larger scale geographic approaches cannot, at least currently, provide detailed information on tree community structure characteristics like tree species diversity and size class distributions of tree populations needed for management. Neither do such larger GIS approaches allow estimations of ecosystem services, which UFORE can.

Chapter 3 provided estimates of the reduction in ecosystem services after trees were lost and damaged in Hurricane Ike in September 2008 and the January 2009 ice storm. The results of the storm damage survey, which revealed that only $33 \%$ of the residents surveyed plan to replace trees lost and damaged in the storms, underscores the importance of interdisciplinary collaboration between ecologists and sociologists in order to maintain sustainable and resilient residential urban forests. 


\section{REFERENCES}

Akbari, H., Taha, H., Huang, J., and A. Rosenfeld. 1986. Undoing uncomfortable summer heat islands can save gigawatts of peak power. Proceedings from the ACEEE 1986 Summer Study on Energy Efficiency in Buildings 2: 7-22.

Akbari, H., Rosenfeld, A.H., and H. Taha. 1990. Summer heat islands, urban trees, and white surfaces. ASHRAE Transactions 96: 1381-1388.

Akbari, H., Davis, S., Huang, J., and S. Winnett. 1992. Cooling our communities: a Guidebook on tree planting and light-colored surfacing. US Environmental Protection Agency, Washington, DC.

Akbari, H. 2002. Shade trees reduce building energy use and $\mathrm{CO}_{2}$ emissions from power plants. Environmental Pollution 116: S119-S126.

Alberti, M. 2009. Advances in Urban Ecology: Integrating Humans and Ecological Processes in Urban Ecosystems. New York: Springer-Verlag, LLC.

American FactFinder. 2011. U.S. Census Bureau. available at: http://factfinder.census.gov/home/saff/main.html?_lang=en

Amman, G.D. and K.C. Ryan. 1991. Insect infestation of fire-injured trees in the greater Yellowstone area. Res. Note INT-398. Ogden, UT: U.S. Department of Agriculture, Forest Service, Intermountain Research Station. 9p.

Bailey, R.G. and C.T. Cushwa. 1981. Ecoregions of North America. U.S. Geological Survey.

Bolund, P. and S. Hunhammar. 1999. Ecosystem services in urban areas. Ecological Economics 29: 293-301.

Botkin DB, Beveridge CE. 1997. Cities as environments. Urban Ecosystems 1:3-19

Carreiro, M.M. and W.C. Zipperer. 2008. Urban forestry and the eco-city: today and tomorrow. In: Carreiro, M.M., Song, Y-C., Wu, J. (eds.). Ecology, Planning, and Management of Urban Forests. New York: Springer. pp.435-456.

Clark, J.R., Matheny, N.P., Cross, G., and V. Wake. 1997. A model of urban forest 
sustainability. Journal of Arboriculture 23: 17-30.

Constanza, R., d'Arge, R., de Groot, R., Farber, S., Grasso, M., Hannon, B., Limburg, K., Naeem, S., O’Neill, R.V., Paruelo, J., Raskin, R.G., Sutton, P., and M. van den Belt. 1997. The value of the world's ecosystem services and natural capital. Nature 387: 253-260.

Council of Tree and Landscape Appraisers. 1992. Guide for plant appraisal. Edited by The International Society of Arboriculture. Savoy, IL: The International Society of Arboriculture.

DeWalle, D.R. 1978. Manipulating urban vegetation for residential energy conservation. Proceedings of the National Urban Forestry Conference. USDA Forest Service, Washington, DC, pp. 267-283.

Dirr, M.A. 1998. Manual of Woody Landscape Plants: Their Identification, Ornamental Characteristics, Culture, Propagation, and Uses. $5^{\text {th }}$ ed. Champaign, IL: Stipes Publishing. 1187p.

Duryea, M.L., Blakeslee, G.M., Hubbard, W.G., and R.A. Vasquez. 1996. Wind and trees: a survey of homeowners after Hurricane Andrew. Journal of Arboriculture 22: 44-49.

Duryea, M.L. 1997. Wind and trees: surveys of tree damage in the Florida Panhandle after Hurricanes Erin and Opal. Circular 1183. Florida Cooperative Extension Service, Institute of Food and Agricultural Sciences, University of Florida pp. 1-8.

Dwyer, J.F., McPherson, E.G., Schroeder, H.W., and R.A. Rowntree. 1992. Assessing the benefits and costs of the urban forest. Journal of Arboriculture 18: 227-234.

Eliasson, I. 1996. Urban nocturnal temperatures, street geometry, and land use. Atmospheric Environment 30: 379-392.

Escobedo, F.J., Nowak, D.J., Wagner, J.E., Luz de la Maza, C., Rodríguez, M., Crane, D.E., and J. Hernández. 2006. The socioeconomics and management of Santiago de Chile's public urban forests. Urban Forestry and Urban Greening 4: 105-114.

Folke, C., Jansson A., Larsson, J, and R. Constanza. 1997. Ecosystem appropriation by cities. Ambio 26: 167-175.

Fowler, D. 2002. Pollutant deposition and uptake by vegetation. In: Bell, J.N.B., Tresow, M. (eds.). Air Pollution and Plant Life. $2^{\text {nd }}$ ed. Chichester, England: John Wiley \& Sons. p. 43-67.

Freedman, B., Love, S., and B. O'Neil. 1996. Tree species composition, structure, and carbon in stands of urban forest of varying character in Halifax, Nova Scotia. The 
Canadian Field Naturalist 110: 675-682.

GNIS (Geographic Names Information System). 2009. Query Form for the United States and Its Territories. Available at: http://geonames.usgs./pls/gnispublic/

Gibbs, J.N. and B.J.W. Greig. 1990. Survey of parkland trees after the great storm of October16, 1987. Arboricultural Journal 14: 321-347.

Grimm, N.B., Grove, J.M., Pickett, S.T.A., and C.L. Redman. 2000. Integrated approaches to long-term studies of urban ecological systems. BioScience 50: 571584.

Grimm, N.B., Faeth, S.H., Golubiewski, N.E, Redman, C.L., Wu, J., Bai, X., and J.M. Briggs. 2008. Global change and the ecology of cities. Science 319: 756-760.

Grimmond, C.S.B. and T.R. Oke. 1995. Comparison of heat fluxes from summertime observations in the suburbs of four North American cities. Journal of Applied Meteorology 34: 873-889.

Haack, R.A., Law, K.R., Mastro, V.C., Ossenbruggen, H.S., and B.J. Raimo. 1997. New York's battle with the Asian long-horned beetle. Journal of Forestry 95:11-15.

Harlan, S.L., Brazel, A.J., Prashad, L., Stefanov, W.L., and L. Larsen. 2006. Neighborhood microclimates and vulnerability to heat stress. Social Science and Medicine 63: 2847-2863.

Harlan, S.L., Brazel, A.J., Jenerette, G.D., Jones, N.S., Larsen, L., Prashad, L., and W.L. Stefanov. 2008. In the shade of affluence: the inequitable distribution of the urban heat island. Research in Social Problems and Public Policy 15: 173-202.

Hauer, R.J., Wang, W., and J.O. Dawson. 1993. Ice storm damage to urban trees. Journal of Arboriculture 19: 187-193.

Heisler, G.M. 1986. Energy savings with trees. Journal of Arboriculture 12(5):113-125.

Heisler, G.M. 1989. Tree plantings that save energy. Proceedings of the Fourth Urban Forestry Conference. USDA Forest Service, St. Louis, MO. pp. 58-62.

Heisler, G.M. 1990. Mean wind speed below building height in residential neighborhoods with different tree densities. ASHRAE Transactions 96: 1389-1396.

Heynen, N. 2006. Green urban political ecologies: toward a better understanding of inner-city environmental change. Environment and Planning A 38: 499-516.

Heynen, N., Perkins, H.A., and P. Roy. 2006. The political ecology of uneven urban green space: the impact of political economy on race and ethnicity in producing 
environmental inequality in Milwaukee. Urban Affairs Review 42: 3-25.

Hope, D., Gries, C., Zhu, W., Fagan, W.F., Redman, C.L., Grimm, N.B., Nelson, A.L., Martin, C., and A. Kinzig. 2003. Socioeconomics drive urban plant diversity. PNAS 100: 8788-8792.

Hutchison, B.A. and F.G. Taylor. 1983. Energy conservation mechanisms and potentials of landscape design to ameliorate building microclimates. Landscape Journal 2: 19-39.

$\mathrm{Jim}$, C.Y. and W.Y. Chen. 2006. Recreation-amenity use and contingent valuation of urban greenspaces in Guangzhou, China. Landscape and Urban Planning 75: 81-96.

Jones, C.G., Ostfeld, R.S., Richard, M.P., Schauber, E.M., and J.O. Wolff. 1998. Chain reactions linking acorns to gypsy moth outbreaks and Lyme disease risk. Science 279: $1023-1026$.

Kentucky Public Service Commission. 2009. Report on the September 2008 Wind Storm and the January 2009 Ice Storm. 170 p. Last accessed: February 23, 2011. Available at: http://psc.ky.gov/Ikelce/Report.pdf

Korpela, K.M. and M. Ylén. 2007. Perceived health is associated with visiting natural favourite places in the vicinity. Health \& Place 13: 138-151.

Kuo, F. E. and W.C. Sullivan. 2001. Environment and crime in the inner city: does vegetation reduce crime? Environment and Behavior 33: 343-367.

Little, E.L. 2006. National Audubon Society Field Guide to Trees: Eastern Region. New York: Alfred A. Knopf. 714p.

Lopes, A., Oliveira, S., Fragoso, M., Andrade, H.A., and P. Pedro. 2007. Wind risk assessment in urban environments: the case of falling trees during windstorm events in Lisbon. In: Střelcová, K., Škvarenina, J., Blaženec, M. (eds.). Bioclimatology and Natural Hazards. International Scientific Conference, Pol'ana nad Detvou, Slovakia, September 17-20, 2007.

Lovett, G.M., Traynor, M.M., Pouyat, R.V., Carreiro, M.M., Zhu, W., and J.W. Baxter. 2000. Atmospheric deposition to oak forests along an urban-rural gradient.

Environmental Science and Technology 34: 4294-4300.

MacFarlane, D.W. and S.P. Meyer. 2005. Characteristics and distribution of potential ash tree hosts for Emerald Ash Borer. Forest Ecology Management 213(1-3): 15-24.

McCune, B. and J.B. Grace. 2002. Analysis of ecological communities. MjM Software Design. Gleneden Beach, OR, USA.

McPherson, E.G. 1994. Cooling urban heat islands with sustainable landscapes. In: Platt, 
R.H., Rowntree, R.A., Muick, P.C. (eds.). The Ecological City: Preserving and Restoring Urban Biodiversity. Amherst, MA: University of Massachusetts Press pp. 151-171.

McPherson, E.G., Nowak, D., Heisler, G., Grimmond, S., Souch, C., Grant, R., Rowntree, R. 1997. Quantifying urban forest structure, function, and value: the Chicago Urban Forest Climate Project Urban Ecosystems 1:49-61.

McPherson, E.G. and J.R. Simpson. 1999. Carbon dioxide reduction through urban forestry: guidelines for professional and volunteer tree planters. Gen. Tech. Rep. PSW-171. Albany, CA: U.S. Department of Agriculture, Forest Service, Pacific Southwest Research Station. 237p.

Morales, D.J. 1980. The contribution of trees to residential property values. Journal of Arboriculture 6: 305-308.

Murray, F.J., Marsh, L., and P.A. Bradford. 1994. New York State energy plan, vol. II: issue reports. Albany, NY: New York State Energy Office.

National Climatic Data Center (NCDC). 2006. Climatological Data Annual SummaryKentucky 2006. Vol. 101, Number 13. ISSN\# 0145-0433. Ashville, NC.

NOAA (National Oceanic and Atmospheric Administration), http://www.crh.noaa.gov/lmk/?n=sep_14_08 and $\mathrm{http}: / /$ www.crh.noaa.gov/lmk/?n=jan_2009_ice_and_snow, accessed January 23, 2010.

Nowak, D.J. 1993. Atmospheric carbon reduction by urban trees. Journal of Environmental Management 37: 207-217.

Nowak, D.J. 1994. Air pollution removal by Chicago's urban forest. In: McPherson, E.G., Nowak, D.J., Rowntree, R.A. (eds.). Chicago's Urban Forest Ecosystems: Results of the Chicago Urban Forest Climate Project. Gen. Tech. Rep. NE-186. Radnor, PA: U.S. Department of Agriculture, Forest Service, Northeastern Research Station: 83-94.

Nowak, D.J., Rowntree, R.A., McPherson, E.G., Sisinni, S.M., Kerkmann, E.R., and J.C. Stevens. 1996. Measuring and analyzing urban tree cover. Landscape and Urban Planning 36: 49-57.

Nowak, D.J. and D.E. Crane. 2000. The Urban Forest Effects (UFORE) model: quantifying urban forest structure and functions. In: Hansen, M., Burk, T. (eds.). Integrated tools for natural resources inventories in the $21^{\text {st }}$ century: proceedings of the IUFRO conference. Gen. Tech. Rep. NC-212, St. Paul, MN: U.S. Department of Agriculture, Forest Service, North Central Research Station: 714-720. 
Nowak, D.J., Crane, D.E., Stevens, J.C., and M. Ibarra. 2002. Brooklyn's Urban Forest. Gen. Tech. Rep. NE-290. Newtown Square, PA: U.S. Department of Agriculture, Forest Service, Northeastern Research Station. 107 p.

Nowak, D.J. and J.F. Dwyer. 2007. Understanding the benefits and costs of urban forest Ecosystems. In: Kuser, J.E. (ed.). Urban and Community Forestry in the Northeast. $2^{\text {nd }}$ ed. New York: Springer pp. 25-46.

Nowak, D.J., Crane, D.E., McHale, P., Binkley, J., Bond, J., Choi, J., Ina, G., Hoehn, R., Luley, C.J., Stevens, J.C., Rian, L., and J.T. Walton. 2007a. i-Tree Software Suite v1.2 User's Manual: Tools for assessing and managing community forests. Syracuse, NY: USDA Forest Service.

Nowak, D.J., Hoehn, R.E.III, Crane, D.E., Stevens, J.C., and J.T. Walton. $2007 \mathrm{~b}$. Assessing urban forest effects and values, Philadelphia's urban forest. Resource Bulletin NRS-7. Newtown Square, PA: U.S. Department of Agriculture, Forest Service, Northern Research Station.

Nowak, D.J., Hoehn, R.E.III, Crane, D.E., Stevens, J.C., and J.T. Walton. 2007c. Assessing urban forest effects and values, San Francisco's urban forest. Resource Bulletin NRS-8. Newtown Square, PA: U.S. Department of Agriculture, Forest Service, Northern Research Station.

Nowak, D.J., Hoehn, R.E.III, Crane, D.E., Stevens, J.C., and J.T. Walton. 2007d. Assessing urban forest effects and values, New York City's urban forest. Resource Bulletin NRS-9. Newtown Square, PA: U.S. Department of Agriculture, Forest Service, Northern Research Station.

Palmer, J.F. 2001. Public survey of residents. In: Nowak, D.J., O'Connor, P.R. (compilers). Syracuse Urban Forest Master Plan: Guiding the City's Forest Resource into the $21^{\text {st }}$ Century. Gen. Tech. Rep. NE-287. Radnor, PA: U.S. Department of Agriculture, Forest Service: 17-19.

Parker, J.H. 1983. Landscaping to reduce the energy used in cooling buildings. Journal of Forestry $81: 82-84$.

Pataki, D.E., Carreiro, M.M., Cherrier, J., Grulke, N., Jennings, V., Pincetl, S., Pouyat, R.V., Whitlow, T.H., and W.C. Zipperer. 2011. Coupling biochemical cycles in urban environments: ecosystem services, green solutions, and misconceptions. Frontiers in Ecology and the Environment 9: 27-36.

Perkins, H.A., Heynen, N., and J. Wilson. 2004. Inequitable access to urban reforestation: the impact of urban political economy on housing tenure and urban forests. Cities 21: 291-299.

Pickett, S. T. A. and P. S. White (eds.). 1985. The Ecology of Natural Disturbance and 
Patch Dynamics. New York: Academic Press.

Pickett, S.T.A., Cadenasso, M.L., Grove, J.M., Nilon, C.H., Pouyat, R.V., Zipperer, W.C., and R. Constanza. 2001. Urban ecological systems: linking terrestrial ecological, physical, and socioeconomic components of metropolitan areas. Annual Review of Ecological Systems 32: 127-157.

Property Valuation Administrator (PVA) of Jefferson County, KY. Accessed on December 20, 2010. Available at: http://jeffersonpva.ky.gov/

Richards, N.A. 1993. Reasonable guidelines for street tree diversity. Journal of Arboriculture 19: 344-349.

Rogers, P. 1996. Disturbance ecology and forest management: a review of the literature. Gen. Tech. Rep. INT-GTR-336. Ogden, UT: U.S. Department of Agriculture, Forest Service, Intermountain Research Station. 16p.

Rolfe, G.L. 1974. Lead distribution in tree rings. Forestry Science 20 :283-286.

Sanders, R.A. 1986. Urban vegetation impacts on urban hydrology of Dayton, Ohio. Urban Ecology 9:361-376.

Schroeder, H.W. and W.N. Cannon. 1987. Visual quality of residential streets: both street and yard trees make a difference. Journal of Arboriculture 13:236-239.

Shuster, W.D., Morrison, M.A., and R. Webb. 2009. Front-loading urban stormwater management for success - a perspective incorporating current studies on the implementation of retrofit low-impact development. Cities and the Environment http://escholarship.bc.edu/cate/vol1/Iss2/8.

Simpson, J.R. 2002. Improved estimates of tree-shade effects on residential energy use. Energy and Buildings 34: 1067-1076.

Sisinni, S.M., Zipperer, W.C., and A.G. Pleninger. 1995. Impacts from a major ice storm: street tree damage in Rochester, New York. Journal of Arboriculture 21: 156-167.

Smardon, R.C. 1988. Perception and aesthetics of the urban environment: review of the role of vegetation. Landscape and Urban Planning 15: 85-106.

Talarchek, G.M. 1990. The urban forest of New Orleans: an exploratory analysis of relationships. Urban Geography 11: 65-86.

Tyrväinen, L. and A. Miettinen. 2000. Property prices and urban forest amenities. Journal of Environmental Economics and Management 39: 205-223.

Tyrväinen, L., Silvennoinen, H., and O. Kolehmainen. 2003. Ecological and aesthetic 
values in urban forest management. Urban Forestry and Urban Greening 1: 135-149.

United Nations, Department of Economic and Social Affairs, Population Division. 2009. World Urbanization Prospects: the 2009 Revision. New York: United Nations. Accessed on February 24, 2011 at http://www.un.org/esa/population/unpop.htm.

United States Department of the Interior. 2009. Bailey's Ecoregions and Subregions of the United States, Puerto Rico, and the U.S. Virgin Islands. Available at: http://www.nationalatlas.gov/mld/ecoregp.html

United States Department of the Interior. 2009. Omernik's Level III Ecoregions of the Continental United States.

Available at: http://www.nationalatlas.gov/mld/ecoormp.html

Vemuri, A.W., Grove, J.M., Wilson, M.A., and W.R. Burch, Jr. 2011. A tale of two scales: evaluating the relationship among life satisfaction, social capital, income, and the natural environment at individual and neighborhood levels in Metropolitan Baltimore. Environment and Behavior 43: 3-25.

Walsh, C.J., Roy, A.H., Feminella, J.W., Cottingham, P.D., Groffman, P.D., and R.P. Morgan II. 2005. The urban stream syndrome: current knowledge and the search for cure. Journal of the North American Benthological Society 24: 706-723.

Whitney, G.G. and S.D. Adams. 1980. Man as a maker of new plant communities. Journal of Applied Ecology 17: 431-448.

Wu, J. 2008. Toward a landscape ecology of cities: beyond buildings, trees, and urban forests. In: Carreiro, M.M., Song, Y-C., Wu, J., (eds.). Ecology, Planning, and Management of Urban Forests. New York: Springer. pp. 10-28.

Wu, J., Huang, C., Wu, W., and S. Zhang. 2008. Urban forest structure in Hefei, China. In: Carreiro, M.M., Song, Y-C., Wu, J., (eds.). Ecology, Planning, and Management of Urban Forests. New York: Springer. pp.279-292.

Xiao, Q., McPherson, E.G., Simpson, J.R., and S.L. Ustin. 1998. Rainfall interception by Sacramento's urban forest. Journal of Arboriculture 24: 235-244.

Ziegler, I. 1973. The effect of air-polluting gases on plant metabolism. In: Environmental Quality and Safety. $2^{\text {nd }}$ ed. New York: Academic Press. p. 182-208.

Zipperer, W.C., Sisinni, S.M., Pouyat, R.V., and T.W. Foresman. 1997. Urban tree cover: an ecological perspective. Urban Ecosystems 1: 229-246. 
Appendix Table 1: 64 tree species and their families found in 100 UFORE plots. Total number of trees in plots $=264$

\begin{tabular}{|c|c|c|c|}
\hline Species & Family & $\begin{array}{l}\text { Percent of } \\
\text { All Trees } \\
\text { Found }\end{array}$ & $\begin{array}{l}\text { Native to } \\
\text { State? }\end{array}$ \\
\hline $\begin{array}{l}\text { Celtis occidentalis } \\
\text { (Northern Hackberry) }\end{array}$ & Ulmaceae & 11.0 & Yes \\
\hline $\begin{array}{l}\text { Acer saccharum } \\
\text { (Sugar Maple) }\end{array}$ & Aceraceae & 6.1 & Yes \\
\hline $\begin{array}{l}\text { Acer saccharinum } \\
\text { (Silver Maple) }\end{array}$ & Aceraceae & 5.7 & Yes \\
\hline $\begin{array}{l}\text { Cercis canadensis } \\
\text { (Eastern Redbud) }\end{array}$ & Fabaceae & 4.5 & Yes \\
\hline $\begin{array}{l}\text { Cornus florida } \\
\text { (Flowering Dogwood) }\end{array}$ & Cornaceae & 4.2 & Yes \\
\hline $\begin{array}{l}\text { Morus rubra } \\
\text { (Red Mulberry) }\end{array}$ & Moraceae & 4.2 & Yes \\
\hline $\begin{array}{l}\text { Acer negundo } \\
\text { (Boxelder) }\end{array}$ & Aceraceae & 3.4 & Yes \\
\hline $\begin{array}{l}\text { Fraxinus pennsylvanica } \\
\text { (Green Ash) }\end{array}$ & Oleaceae & 3.4 & Yes \\
\hline $\begin{array}{l}\text { Malus species } \\
\text { (Crab Apple) }\end{array}$ & Rosaceae & 3.4 & No \\
\hline $\begin{array}{l}\text { Morus alba } \\
\text { (White Mulberry) }\end{array}$ & Moraceae & 3.4 & No \\
\hline $\begin{array}{l}\text { Prunus serotina } \\
\text { (Black Cherry) }\end{array}$ & Rosaceae & 3.0 & Yes \\
\hline $\begin{array}{l}\text { Acer rubrum } \\
\text { (Red Maple) }\end{array}$ & Aceraceae & 2.3 & Yes \\
\hline $\begin{array}{l}\text { Juniperus virginiana } \\
\text { (Eastern Redcedar) }\end{array}$ & Cupressaceae & 2.3 & Yes \\
\hline $\begin{array}{l}\text { Pyrus species } \\
\text { (Pear) }\end{array}$ & Rosaceae & 2.3 & No \\
\hline $\begin{array}{l}\text { Cornus kousa } \\
\text { (Kousa Dogwood) }\end{array}$ & Cornaceae & 1.9 & No \\
\hline $\begin{array}{l}\text { Fagus grandifolia } \\
\text { (American Beech) }\end{array}$ & Fagaceae & 1.9 & Yes \\
\hline $\begin{array}{l}\text { Quercus palustris } \\
\text { (Pin Oak) }\end{array}$ & Fagaceae & 1.9 & Yes \\
\hline $\begin{array}{l}\text { Tsuga canadensis } \\
\text { (Eastern Hemlock) }\end{array}$ & Pinaceae & 1.9 & Yes \\
\hline $\begin{array}{l}\text { Albizia julibrissin } \\
\text { (Mimosa-tree) }\end{array}$ & Fabaceae & 1.5 & No \\
\hline $\begin{array}{l}\text { Nyssa sylvatica } \\
\text { (Black Tupelo) }\end{array}$ & Cornaceae & 1.5 & Yes \\
\hline
\end{tabular}




\begin{tabular}{|c|c|c|c|}
\hline $\begin{array}{l}\text { Picea abies } \\
\text { (Norway Spruce) }\end{array}$ & Pinaceae & 1.5 & No \\
\hline $\begin{array}{l}\text { Pinus strobus } \\
\text { (Eastern White Pine) }\end{array}$ & Pinaceae & 1.5 & Yes \\
\hline $\begin{array}{l}\text { Taxus baccata } \\
\text { (English Yew) }\end{array}$ & Taxaceae & 1.5 & No \\
\hline $\begin{array}{l}\text { Fraxinus americana } \\
\text { (White Ash) }\end{array}$ & Oleaceae & 1.1 & Yes \\
\hline $\begin{array}{l}\text { Ilex opaca } \\
\text { (American Holly) }\end{array}$ & Aquifoliaceae & 1.1 & Yes \\
\hline $\begin{array}{l}\text { Picea pungens } \\
\text { (Blue Spruce) }\end{array}$ & Pinaceae & 1.1 & No \\
\hline $\begin{array}{l}\text { Pinus taeda } \\
\text { (Loblolly Pine) }\end{array}$ & Pinaceae & 1.1 & No \\
\hline $\begin{array}{l}\text { Pyrus calleryana } \\
\text { (Callery Pear) }\end{array}$ & Rosaceae & 1.1 & No \\
\hline $\begin{array}{l}\text { Robinia pseudoacacia } \\
\text { (Black Locust) }\end{array}$ & Fabaceae & 1.1 & Yes \\
\hline $\begin{array}{l}\text { Taxus species } \\
\text { (Yew) }\end{array}$ & Taxaceae & 1.1 & No \\
\hline $\begin{array}{l}\text { Acer platanoides } \\
\text { (Norway Maple) }\end{array}$ & Aceraceae & 0.8 & No \\
\hline $\begin{array}{l}\text { Ginkgo biloba } \\
\text { (Gingko) }\end{array}$ & Gingkoaceae & 0.8 & No \\
\hline $\begin{array}{l}\text { Gleditsia triacanthos } \\
\text { (Honeylocust) }\end{array}$ & Fabaceae & 0.8 & Yes \\
\hline $\begin{array}{l}\text { Koelreuteria paniculata } \\
\text { (Goldenrain Tree) }\end{array}$ & Sapindaceae & 0.8 & No \\
\hline $\begin{array}{l}\text { Liriodendron tulipifera } \\
\text { (Tulip-poplar) }\end{array}$ & Magnoliaceae & 0.8 & Yes \\
\hline $\begin{array}{l}\text { Prunus serrulata } \\
\text { (Kwanzan Cherry) }\end{array}$ & Rosaceae & 0.8 & No \\
\hline $\begin{array}{l}\text { Pyrus communis } \\
\text { (Common Pear) }\end{array}$ & Rosaceae & 0.8 & No \\
\hline $\begin{array}{l}\text { Quercus alba } \\
\text { (White Oak) }\end{array}$ & Fagaceae & 0.8 & Yes \\
\hline $\begin{array}{l}\text { Quercus rubra } \\
\text { (Northern Red Oak) }\end{array}$ & Fagaceae & 0.8 & Yes \\
\hline $\begin{array}{l}\text { Quercus velutina } \\
\text { (Black Oak) }\end{array}$ & Fagaceae & 0.8 & Yes \\
\hline $\begin{array}{l}\text { Taxodium distichum } \\
\text { (Bald-cypress) }\end{array}$ & Cupressaceae & 0.8 & Yes \\
\hline $\begin{array}{l}\text { Thuja occidentalis } \\
\text { (Northern White-cedar) }\end{array}$ & Cupressaceae & 0.8 & No \\
\hline $\begin{array}{l}\text { Ulmus rubra } \\
\text { (Slippery Elm) }\end{array}$ & Ulmaceae & 0.8 & No \\
\hline
\end{tabular}




\begin{tabular}{|c|c|c|c|}
\hline $\begin{array}{l}\text { Betula nigra } \\
\text { (River Birch) }\end{array}$ & Betulaceae & 0.4 & Yes \\
\hline $\begin{array}{l}\text { Carya ovata } \\
\text { (Shagbark Hickory) }\end{array}$ & Juglandaceae & 0.4 & Yes \\
\hline $\begin{array}{l}\text { Ilex aquifolium } \\
\text { (English Holly) }\end{array}$ & Aquifoliaceae & 0.4 & No \\
\hline $\begin{array}{l}\text { Juglans nigra } \\
\text { (Black Walnut) }\end{array}$ & Juglandaceae & 0.4 & Yes \\
\hline $\begin{array}{l}\text { Juniperus species } \\
\text { (Juniper) }\end{array}$ & Cupressaceae & 0.4 & No \\
\hline $\begin{array}{l}\text { Liquidambar styraciflua } \\
\text { (Sweetgum) }\end{array}$ & Hamamelidaceae & 0.4 & Yes \\
\hline $\begin{array}{l}\text { Magnolia grandiflora } \\
\text { (Southern Magnolia) }\end{array}$ & Magnoliaceae & 0.4 & No \\
\hline $\begin{array}{l}\text { Magnolia species } \\
\text { (Magnolia) }\end{array}$ & Magnoliaceae & 0.4 & No \\
\hline $\begin{array}{l}\text { Magnolia } x \text { soulangeana } \\
\text { (Saucer Magnolia) }\end{array}$ & Magnoliaceae & 0.4 & No \\
\hline $\begin{array}{l}\text { Malus coronaria } \\
\text { (Sweet Crab Apple) }\end{array}$ & Rosaceae & 0.4 & Yes \\
\hline $\begin{array}{l}\text { Malus sylvestris } \\
\text { (Apple) }\end{array}$ & Rosaceae & 0.4 & No \\
\hline $\begin{array}{l}\text { Platanus occidentalis } \\
\text { (American Sycamore) }\end{array}$ & Platanaceae & 0.4 & Yes \\
\hline $\begin{array}{l}\text { Populus tremuloides } \\
\text { (Quaking Aspen) }\end{array}$ & Salicaceae & 0.4 & No \\
\hline $\begin{array}{l}\text { Prunus persica } \\
(\text { Peach })\end{array}$ & Rosaceae & 0.4 & No \\
\hline $\begin{array}{l}\text { Prunus } x \text { cistena } \\
\text { (Purpleleaf Sand Cherry) }\end{array}$ & Rosaceae & 0.4 & No \\
\hline $\begin{array}{l}\text { Pseudotsuga menziesii } \\
\text { (Douglas-fir) }\end{array}$ & Pinaceae & 0.4 & No \\
\hline $\begin{array}{l}\text { Quercus bicolor } \\
\text { (Swamp White Oak) }\end{array}$ & Fagaceae & 0.4 & Yes \\
\hline $\begin{array}{l}\text { Quercus imbricaria } \\
\text { (Shingle Oak) }\end{array}$ & Fagaceae & 0.4 & Yes \\
\hline $\begin{array}{l}\text { Salix nigra } \\
\text { (Black Willow) }\end{array}$ & Salicaceae & 0.4 & No \\
\hline $\begin{array}{l}\text { Thuja species } \\
\text { (Cedar) }\end{array}$ & Cupressaceae & 0.4 & No \\
\hline $\begin{array}{l}\text { Tilia europaea } \\
\text { (European Linden) }\end{array}$ & Tiliaceae & 0.4 & No \\
\hline
\end{tabular}


Appendix Table 2: Plot number, plot identification number, and address for all 100 UFORE plots. The plot identification number is the unique number used to designate the plot on the GIS overlays as well as on all UFORE forms.

\begin{tabular}{|c|c|c|}
\hline Plot \# & $\begin{array}{l}\text { Plot } \\
\text { ID\# }\end{array}$ & Address \\
\hline 1 & $2-1$ & 1224 Dahl Road, Louisville, KY 40213 \\
\hline 2 & $2-2$ & 5515 Lagoona Drive, Louisville, KY 40219 \\
\hline 3 & $2-6$ & 5902 Oakdale Lane, Louisville, KY 40219 \\
\hline & & 5904 Oakdale Lane, Louisville, KY 40219 \\
\hline 4 & $2-9$ & 5002 Ellington Avenue, Louisville, KY 40218 \\
\hline 5 & $2-12$ & 4700 Fern Valley Road, Louisville, KY 40219 \\
\hline 6 & $2-21$ & 4118 Sanford Avenue, Louisville, KY 40218 \\
\hline & & 4124 Sanford Avenue, Louisville, KY 40218 \\
\hline 7 & $2-22$ & 1438 Forest Drive, Louisville, KY 40219 \\
\hline 8 & $2-23$ & 5012 Ellington Avenue, Louisville, KY 40218 \\
\hline 9 & $2-24$ & 5917 Prestwood Court, Louisville, KY 40219 \\
\hline & & 1215 Forest Drive, Louisville, KY 40219 \\
\hline & & 1219 Forest Drive, Louisville, KY 40219 \\
\hline 10 & $2-28$ & 4604 Balaton Drive, Louisville, KY 40219 \\
\hline & & 4606 Balaton Drive, Louisville, KY 40219 \\
\hline 11 & $3-6$ & 4534 Stonestreet Avenue, Louisville, KY 40216 \\
\hline 12 & $3-9$ & 1600 S. 31st Street, Louisville, KY 40211 \\
\hline 13 & $3-11$ & 4608 Spen Lea Road, Louisville, KY 40216 \\
\hline 14 & $3-12$ & 4003 Glenhurst Avenue, Louisville, KY 40216 \\
\hline 15 & $3-14$ & 2240 Thistledawn Drive, Louisville, KY 40216 \\
\hline & & 2242 Thistledawn Drive, Louisville, KY 40216 \\
\hline 16 & $3-19$ & 1807 Farnsley Road, Louisville, KY 40216 \\
\hline
\end{tabular}




\begin{tabular}{|c|c|c|}
\hline & & 1809 Farnsley Road, Louisville, KY 40216 \\
\hline \multirow[t]{2}{*}{17} & $3-22$ & 2110 Ratcliffe Avenue, Louisville, KY 40210 \\
\hline & & 2112 Ratcliffe Avenue, Louisville, KY 40210 \\
\hline \multirow[t]{3}{*}{18} & $3-24$ & 1714 Model Road, Louisville, KY 40216 \\
\hline & & 1715 Model Road, Louisville, KY 40216 \\
\hline & & 1716 Model Road, Louisville, KY 40216 \\
\hline \multirow[t]{2}{*}{19} & $3-29$ & 4130 Mill Creek Drive, Louisville, KY 40216 \\
\hline & & 4132 Mill Creek Drive, Louisville, KY 40216 \\
\hline 20 & $3-32$ & 3102 Clinton Place, Louisville, KY 40216 \\
\hline \multirow[t]{2}{*}{21} & $5-1$ & 2323 Portland Avenue, Louisville, KY 40212 \\
\hline & & 2327 Portland Avenue, Louisville, KY 40212 \\
\hline \multirow[t]{2}{*}{22} & $5-4$ & 2309 Portland Avenue, Louisville, KY 40212 \\
\hline & & 2311 Portland Avenue, Louisville, KY 40212 \\
\hline \multirow[t]{3}{*}{23} & $5-7$ & 1625 Bank Street, Louisville, KY 40203 \\
\hline & & 1627 Bank Street, Louisville, KY 40203 \\
\hline & & 1629 Bank Street, Louisville, KY 40203 \\
\hline \multirow[t]{2}{*}{24} & $5-13$ & 317 Shawnee Drive, Louisville, KY 40212 \\
\hline & & 319 Shawnee Drive, Louisville, KY 40212 \\
\hline \multirow[t]{2}{*}{25} & $5-14$ & 2415 Portland Avenue, Louisville, KY 40212 \\
\hline & & 2417 Portland Avenue, Louisville, KY 40212 \\
\hline \multirow[t]{2}{*}{26} & $5-15$ & 105 N. Longworth Avenue, Louisville, KY 40212 \\
\hline & & 107 N. Longworth Avenue, Louisville, KY 40212 \\
\hline \multirow[t]{2}{*}{27} & $5-19$ & 3918 Pflanz Avenue, Louisville, KY 40212 \\
\hline & & 3920 Pflanz Avenue, Louisville, KY 40212 \\
\hline 28 & $5-29$ & 3130 W. Jefferson Street, Louisville, KY 40212 \\
\hline 29 & $5-36$ & 3502 Northwestern Parkway, Louisville, KY 40212 \\
\hline \multirow[t]{2}{*}{30} & $5-38$ & 4600 W. Jefferson Street, Louisville, KY 40212 \\
\hline & & 4604 W. Jefferson Street, Louisville, KY 40212 \\
\hline 31 & $7-3$ & 315 Lotis Way, Louisville, KY 40207 \\
\hline
\end{tabular}




\begin{tabular}{|c|c|c|}
\hline 32 & $7-5$ & 7207 Glen Arbor Road, Louisville, KY 40222 \\
\hline \multirow[t]{2}{*}{33} & $7-7$ & 322 Sage Road, Louisville, KY 40207 \\
\hline & & 324 Sage Road, Louisville, KY 40207 \\
\hline \multirow[t]{2}{*}{34} & $7-9$ & 302 Blankenbaker Lane, Louisville, KY 40207 \\
\hline & & 304 Blankenbaker Lane, Louisville, KY 40207 \\
\hline \multirow[t]{2}{*}{35} & $7-11$ & 130 Gibson Road, Louisville, KY 40207 \\
\hline & & 200 Gibson Road, Louisville, KY 40207 \\
\hline 36 & $7-13$ & 8102 Partridge Meadow Drive, Louisville, KY 40222 \\
\hline 37 & $7-18$ & 210 Brunswick Road, Louisville, KY 40207 \\
\hline 38 & $7-19$ & 7001 Graymoor Road, Louisville, KY 40222 \\
\hline 39 & $7-24$ & 5209 Tomahawk Road, Louisville, KY 40207 \\
\hline \multirow[t]{2}{*}{40} & $7-25$ & 500 Washburn Avenue, Louisville, KY 40222 \\
\hline & & 504 Washburn Avenue, Louisville, KY 40222 \\
\hline 41 & $8-1$ & 1700 Trevilian Way, Louisville, KY 40205 \\
\hline \multirow[t]{2}{*}{42} & $8-2$ & 2132 Maryland Avenue, Louisville, KY 40205 \\
\hline & & 2136 Maryland Avenue, Louisville, KY 40205 \\
\hline \multirow[t]{2}{*}{43} & $8-3$ & 1817 Deer Park Avenue, Louisville, KY 40205 \\
\hline & & 1819 Deer Park Avenue, Louisville, KY 40205 \\
\hline 44 & $8-5$ & 2440 Boulevard Napoleon, Louisville, KY 40205 \\
\hline \multirow[t]{2}{*}{45} & $8-7$ & 1238 Eastern Parkway, Louisville, KY 40204 \\
\hline & & 1246 Eastern Parkway, Louisville, KY 40204 \\
\hline \multirow[t]{2}{*}{46} & $8-8$ & 1248 Cherokee Road, Louisville, KY 40204 \\
\hline & & 1252 Cherokee Road, Louisville, KY 40204 \\
\hline \multirow[t]{2}{*}{47} & $8-10$ & 1712 Edenside Avenue, Louisville, KY 40204 \\
\hline & & 1714 Edenside Avenue, Louisville, KY 40204 \\
\hline \multirow[t]{2}{*}{48} & $8-12$ & 2421 Ransdell Avenue, Louisville, KY 40204 \\
\hline & & 2423 Ransdell Avenue, Louisville, KY 40204 \\
\hline 49 & $8-16$ & 1046 Dudley Avenue, Louisville, KY 40204 \\
\hline
\end{tabular}




\begin{tabular}{|c|c|c|}
\hline 50 & $8-20$ & 2316 Bonnycastle Avenue, Louisville, KY 40205 \\
\hline 51 & $9-5$ & 626 Emily Road, Louisville, KY 40206 \\
\hline 52 & $9-11$ & 1213 Park Hills Drive, Louisville, KY 40207 \\
\hline & & 1201 Park Hills Court, Louisville, KY 40207 \\
\hline 53 & $9-13$ & 201 Fairlawn Road, Louisville, KY 40207 \\
\hline & & 203 Fairlawn Road, Louisville, KY 40207 \\
\hline 54 & $9-17$ & 2817 Brownsboro Road, Louisville, KY 40206 \\
\hline 55 & $9-18$ & 415 James Road, Louisville, KY 40206 \\
\hline 56 & $9-19$ & 703 Circle Hill Road, Louisville, KY 40207 \\
\hline 57 & $9-21$ & 232 S. Bayly Avenue, Louisville, KY 40206 \\
\hline & & 236 S. Bayly Avenue, Louisville, KY 40206 \\
\hline 58 & $9-22$ & 301 Pepperbush Road, Louisville, KY 40207 \\
\hline 59 & $9-24$ & 300 Masonic Home Drive, Louisville, KY 40207 \\
\hline 60 & $9-40$ & 3216 Beals Branch Road, Louisville, KY 40206 \\
\hline 61 & $14-2$ & 6606 Bethany Lane, Louisville, KY 40272 \\
\hline 62 & $14-3$ & 7702 Marie Anna Drive, Louisville, KY 40258 \\
\hline 63 & $14-10$ & 5302 Pendleton Road, Louisville, KY 40272 \\
\hline 64 & $14-16$ & 6305 Faris Way, Louisville, KY 40272 \\
\hline 65 & $14-18$ & 7913 Kenhurst Drive, Louisville, KY 40258 \\
\hline 66 & $14-25$ & 7906 Trillium Drive, Louisville, KY 40258 \\
\hline 67 & $14-30$ & 7210 Scenic Trail, Louisville, KY 40272 \\
\hline 68 & $14-44$ & 14008 Petwood Boulevard, Louisville, KY 40272 \\
\hline 69 & $14-45$ & 8312 Aspen Avenue, Louisville, KY 40258 \\
\hline 70 & $14-48$ & 6807 Whipple Road, Louisville, KY 40272 \\
\hline
\end{tabular}




\begin{tabular}{|c|c|c|}
\hline 71 & $18-1$ & 505 Leicester Circle, Louisville, KY 40222 \\
\hline 72 & $18-3$ & 8506 Leyton Court, Louisville, KY 40222 \\
\hline 73 & $18-5$ & 2415 Old Hickory Road, Louisville, KY 40299 \\
\hline 74 & $18-12$ & 8220 Oxmoor Farm Lane, Louisville, KY 40222 \\
\hline 75 & $18-16$ & 607 Pennyroyal Way, Louisville, KY 40223 \\
\hline & & 609 Pennyroyal Way, Louisville, KY 40223 \\
\hline 76 & $18-18$ & 531 Leicester Circle, Louisville, KY 40222 \\
\hline 77 & 18-19 & 1915 Janlyn Road, Louisville, KY 40299 \\
\hline 78 & $18-22$ & 1306 Gallant Fox Run Road, Louisville, KY 40242 \\
\hline & & 1308 Gallant Fox Run Road, Louisville, KY 40242 \\
\hline 79 & $18-23$ & 10320 Timberwood Circle, Louisville, KY 40223 \\
\hline 80 & $18-30$ & $\begin{array}{l}700 \text { Colonel Anderson Parkway, Louisville, KY } \\
40222\end{array}$ \\
\hline 81 & $24-3$ & 5304 Chathamwood Drive, Louisville, KY 40229 \\
\hline 82 & $24-5$ & 1103 Farman Court, Louisville, KY 40219 \\
\hline 83 & $24-7$ & 5604 Minyard Drive, Louisville, KY 40219 \\
\hline & & 5606 Minyard Drive, Louisville, KY 40219 \\
\hline 84 & $24-19$ & 8312 Siesta Way, Louisville, KY 40219 \\
\hline 85 & $24-25$ & 3900 Oakleaf Lane, Louisville, KY 40219 \\
\hline & & 8203 Westray Lane, Louisville, KY 40219 \\
\hline 86 & $24-26$ & 10930 Bier Lane, Louisville, KY 40229 \\
\hline 87 & $24-34$ & 1034 Reeves Road, Louisville, KY 40219 \\
\hline & & 1036 Reeves Road, Louisville, KY 40219 \\
\hline 88 & $24-39$ & 3900 Hillcross Drive, Louisville, KY 40229 \\
\hline 89 & $24-40$ & 11718 Maple Way, Louisville, KY 40229 \\
\hline
\end{tabular}




\begin{tabular}{|c|l|l|}
$\mathbf{9 0}$ & $24-41$ & 5001 Maple Springs Drive, Louisville, KY 40229 \\
\hline $\mathbf{9 1}$ & $25-7$ & 4423 South Ridge Drive, Louisville, KY 40272 \\
\hline & & \\
\hline $\mathbf{9 2}$ & $25-14$ & 10204 Starlight Way, Louisville, KY 40272 \\
\hline & & 10206 Starlight Way, Louisville, KY 40213 \\
\hline & & \\
\hline $\mathbf{9 3}$ & $25-16$ & 8113 Arnoldtown Road, Louisville, KY 40214 \\
\hline & & 8117 Arnoldtown Road, Louisville, KY 40214 \\
\hline & & \\
\hline $\mathbf{9 4}$ & $25-19$ & 11809 Mahogany Drive, Louisville, KY 40272 \\
\hline & & 11811 Mahogany Drive, Louisville, KY 40272 \\
\hline & & \\
\hline $\mathbf{9 5}$ & $25-24$ & 5422 Southview Drive, Louisville, KY 40214 \\
\hline & & \\
\hline $\mathbf{9 6}$ & $25-30$ & 7524 Merlyn Circle, Louisville, KY 40214 \\
\hline & & 7526 Merlyn Circle, Louisville, KY 40214 \\
\hline & & \\
\hline $\mathbf{9 7}$ & $25-33$ & 3612 Brenden Wood Road, Louisville, KY 40272 \\
\hline & & \\
\hline $\mathbf{9 8}$ & $25-34$ & 10786 Tarrytowne Drive, Louisville, KY 40272 \\
\hline & & 10787 Millers Lane, Louisville, KY 40272 \\
\hline & & \\
\hline $\mathbf{9 9}$ & $25-39$ & 10507 S. Dodge Lane, Louisville, KY 40272 \\
\hline & & \\
\hline $\mathbf{1 0 0}$ & $25-40$ & 9006 Mitchell Lane, Louisville, KY 40272 \\
\hline & & \\
\hline
\end{tabular}



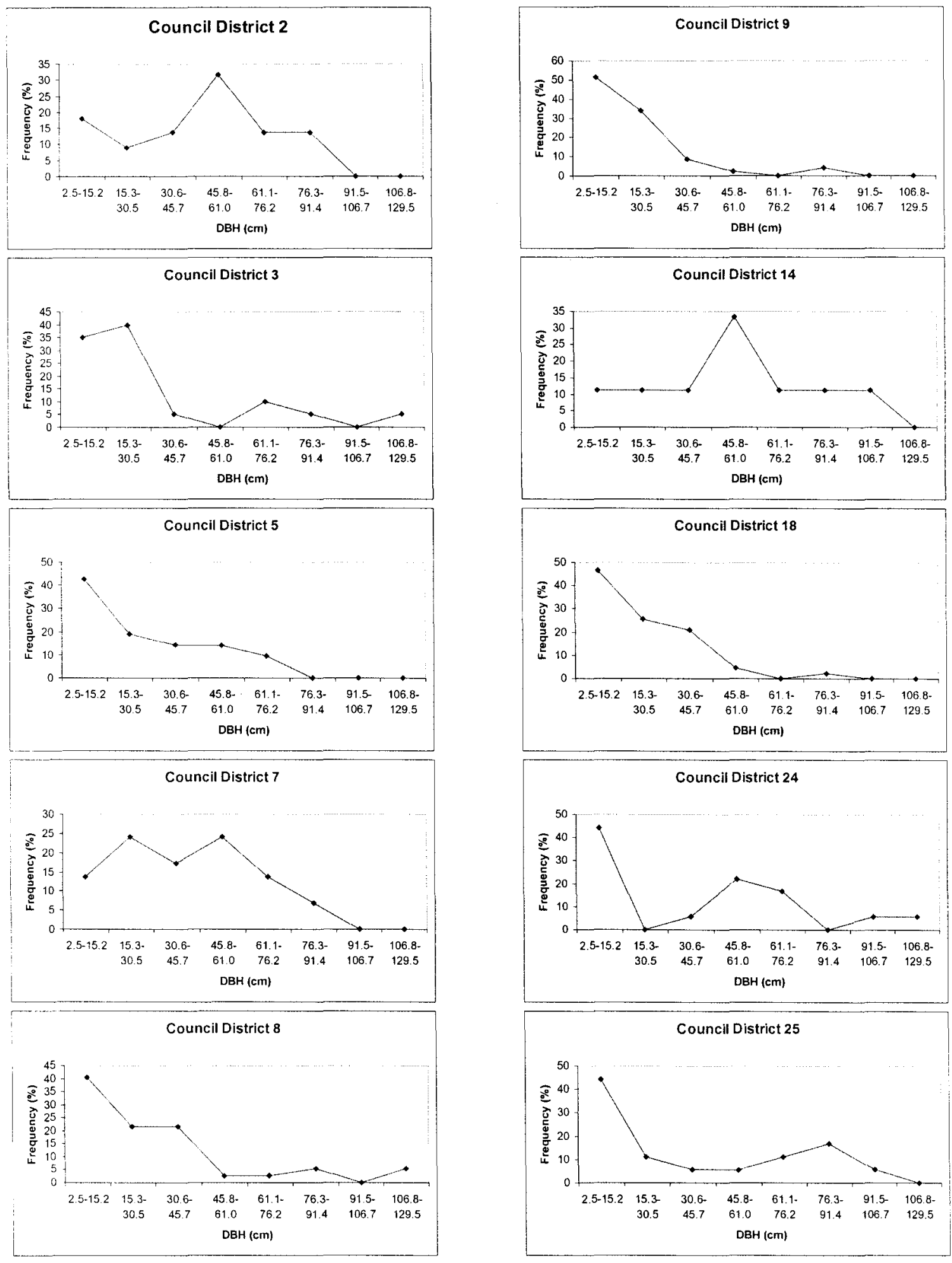

Appendix Figure 1: Percent frequency of DBH (cm) size class in residential land in 10 council districts. Percent frequency indicates what percentage a given size class constitutes of the total population of trees for that council district. 


\title{
CURRICULUM VITAE
}

\author{
Shannon Amanda Scroggins \\ Department of Biology \\ Life Science 139 \\ University of Louisville \\ Louisville, KY 40292
}

\section{EDUCATION}

B.S. Nursing, Jacksonville University, Jacksonville, FL. 2005

\section{PROFESSIONAL POSITIONS}

Teaching Assistant. Biology Department, University of Louisville, Louisville, KY. $(8 / 07-6 / 09,1 / 10-6 / 10)$

Surgical Technologist, Audubon Hospital, Louisville, KY. (3/06-12/07)

Surgical Technologist, Pikeville Medical Center, Pikeville, KY. (6/03-2/06)

Registered Nurse, Pikeville Medical Center, Pikeville, KY.

(1/03-5/03, 6/04-12/04)

Registered Nurse, Eastside Hospital, Redmond, WA.

(6/99-12/02)

Registered Nurse, Seattle VA Medical Center, Seattle, WA.

(7/00-3/01)

Delivery Room Technician, Eastside Hospital, Redmond, WA.

(9/98-6/99)

Surgical Technologist, Eastside Hospital, Redmond, WA.

(7/95-9/98)

Licensed Practical Nurse, Eastside Hospital, Redmond, WA. (2/93-7/95)

\section{SCHOLASTIC AND PROFESSIONAL HONORS}

Beechmont Garden Club Award for Outstanding Research $\$ 500$ (2010)

Bill Furnish Award for Excellence in Teaching Biology \$500 (2009)

Commission on Diversity and Racial Equality (CODRE) Grant $\$ 1000$ (2008) 
Golden Key International Honour Society (Inducted 2008)

\section{ORAL PRESENTATIONS}

Scroggins, S.A. and M.M. Carreiro. 2010. Residential tree damage and loss of ecosystem services in Louisville, Kentucky from Hurricane Ike and the January 2009 ice storm. $96^{\text {th }}$ Annual Meeting of the Kentucky Academy of Science, Bowling Green, KY, USA.

Scroggins, S.A. and M.M. Carreiro. 2009. Comparing soil heavy metal concentrations across Louisville's residential yards. Meeting of the Commission on Diversity and Racial Equality (CODRE), Louisville, KY, USA.

\section{POSTER PRESENTATIONS}

Scroggins, S.A. and M.M. Carreiro. 2009. Estimating the environmental benefit of Louisville's residential trees using the Urban Forest Effects (UFORE) model. $1^{\text {st }}$ Annual Graduate Research Symposium, Louisville, KY, USA.

Scroggins, S.A., Trammell, T.L.E., and M.M. Carreiro. 2007. Woody plant production and leaf area index along urban-rural highway gradients in Louisville, KY. $92^{\text {nd }}$ Annual Meeting of the Ecological Society of America. San Jose, CA, USA. $93^{\text {rd }}$ Annual Meeting of the Kentucky Academy of Science, Louisville, KY, USA. 